\title{
A SURVEY OF AGENTS AND TECHNIQUES APPLICABLE TO THE SOLIDIFICATION OF LOW-LEVEL RADIOACTIVE WASTES
}

\author{
M. Fuhrmann, R.M. Neilson, Jr., and P. Colombo
}

December 1981

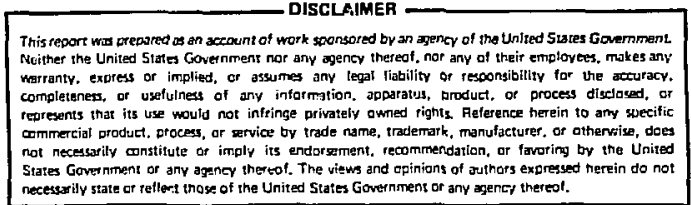

NUCLEAR WASTE RESEARCH GROUP BEPARTMENT OF NUCLEAR ENERGY BROOKHAVEN NATIONAL LABORATORY ASSOCIATED UNIVERSITIES, INC. UPTON, LONG ISLAND, NEW YORK. 11973

Prepared for the NATIONAL LOW-LEVEL WASTE PROGRAM UNITED STATES DEPARTMENT OF ENERGY CONTRACT NO. DE-ACO2-76CHOOO16 


\section{DISCLAIMER}

This report was prepared as an account of work sponsored by an agency of the United States Government. Neither the United States Government nor any agency thereof, nor any of their employees, nor any of their contractors, subcontractors, or their employees, makes any warranty, express or implied, or assumes any legal liability or responsibility for the accuracy, completeness, or usefulness of any information, apparatus, product, or process disclosed, or represents that its use would not infringe privately owned rights. Reference herein to any specific commercial product. process, or service by trade name, trademark, manufacturer, or otherwise, does not necessarily constitute or imply its endorsement, recommendation, or favoring by the United States Government or any agency, contractor or subcontractor thereof. The views and opinions of authors expressed herein do not necessarily state or reflect those of the United States Government or any agency, contractor or subcontractor thereof.

Printed in the United States of America

Available from

National Technical Information Service

U.S. Department of Commerce

5285 Port Royal Road

Springfield, VA 2216I

NTIS price codes:

Printed Copy: A08; Microfiche Copy: A01 


\section{SUMMARY}

This report presents a review of the various solidification agents and techniques that are currently available or potentially applicable for the solidification of low-level radioactive wastes. An overview of the types and quantities of low-level wastes produced is presented. Descriptions of waste form matrix materials, the wastes types for which they have been or may be applied and available information concerning relevant waste form properties and characteristics follow. Also included are descriptions of the processing techniques themselves with an emphasis on those operating parameters which impact upon waste form properties. The solidification agents considered in this survey include: hydraulic cements, thermoplastic materials, thermosetting polymers, glasses, synthetic minerals and composite materials.

This survey is part of a program supported by the Unites States Department of Energy's Low-Level Waste Management Program (IIWMP). This work provides input into IIWMP efforts to develop and compile information reievant to the treatment and processing of low-level wastes and their disposal by shallow land burial. 


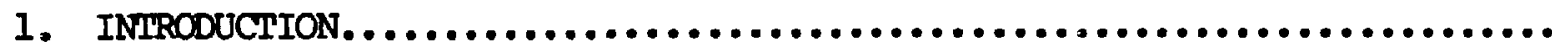

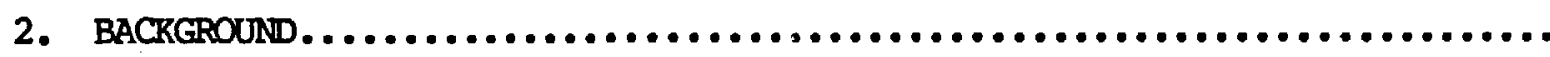

2.1 Purpose of Solidification................................

2.2 Low-Level Radicactive Wastes............................

2,2,1 Sources and Types of Low-Level Wastes.

3. HYDRAULIC CEMENIS AS AGENIS FOR LOW-LEVEL WASTE SOLIDIFICATION.

3.1 Description of Hydraulic Cements.

3.2 Types of Bydraulic Cements.................................

3.3 Additives.

3.4 Solidification Processes Using Bydraulic Cements................

3.4.1 Drum Mixing.

3.4.2 In-Line Mixing.

3.4.3 Cementitious Grouts.

3.4.4 Hot Pressed Cements.

3.4.5 FUETAP

3.4.6 Cold Pressed Cements.

3.4.7 Surface Treatments

3.5 Waste Form Characteristics.

3.5.1 Chemical Compatibility of Wastes...................... 
3.5.3 Mechanical Strength.............................. 36

3.5.4 Radiation Stability............................... 39

3.5.5. Thermal Properties................................. 43

3.6 Advantages and Disadvantages............................. 44

REFERENCES................................................... 46

4. BITUMEN AS AN AGENT FOR LOW-LEVEL WASTE SOLIDIFICATION.............. 48

4.1 Description of Bitumen.................................. 48

4.2 Types of Bitumen.......................................... 49

4.3 Additives.............................................. 50

4.4 Waste Form Preparacion................................. 52

4.4.1 Stirred Bitumen Process (Mol Method).................... 52

4.4.2 The "Temporary Enulsion" Process....................... 54

4.4.3 Sedimentation Process.............................. 55

4.4.4 Screw Extruder Process.............................. 58

4.4.5 Emulsified Bitumen Process.......................... 60

4.5 Bitumen Waste Form Characteristics......................... 61

4.5.1 Chemical Compatibility of Waste..................... 61

4.5 .2 Leachability..................................... 63

4.5.3 Mechanical Properties............................. 68

4.5.4 Radiation Stability............................... 69

4.5.5 Thermal Properties................................ 69

4.6 Advantages and Disadvantages............................ 70

REFERENCES................................................. 72 


\section{TABLE OF CONIFENIS (CONT.)}

Rage

5. POLYEIHYLENE AS AN AGENT FOR LOW-LEVEL WASTE SOLIDIFICATION.......... 73

5.1 Description of Polyethylene............................. 73

5.2 Types of Polyethylenes................................ 73

5.3 Additives............................................ 74

5.4 Solidification Processes Using Polyethylene.................... 74

5.4.1 Wiped Film Evaporators............................ 74

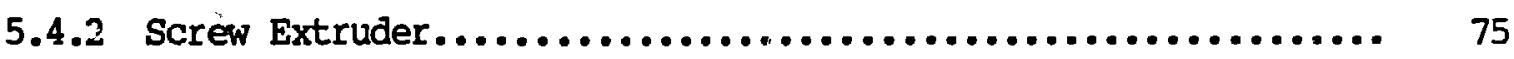

5.5 Polyethylene Waste Form Characteristics.................... 75

5.5.1 Chemical Compatibility of Wastes...................... 75

5.5.2 Leachability................................. 76

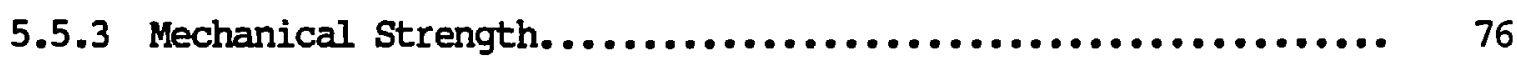

5.5 .4 Radiation Stability............................ 76

5.5.5 Thermal Properties............................... 78

5.6 Advantages and Disadvantages........................... 78

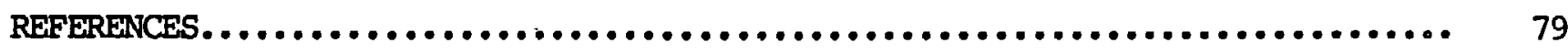

6. UREA-FORMALDEHYDE RESIN AS AN AGENT FOR LOW-LEVEU WASTE SOLIDIFICATION.. 80

6.1 Description of Urea-Formaldehyde........................ 80

6.2 Additives................................................. 81

6.3. Solidification Processes Using Urea-fomaldehyde............... 81

6.3.1 In-container Mixing............................ 82

6.3.2 In-line Mixing.................................. 83

6.4 Urea-Formaldehyde Waste Form Characteristics................. 83

6.4.1 Chemical Compatibility of Wastes..................... 83

6.4.2 Free-Standing water.............................. 85

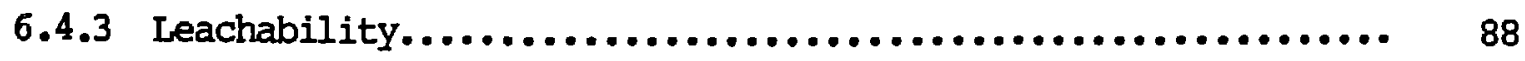




\section{TABLE OF CONHENISS (CONR.)}

Page

6.4.4 Mechanical Strength............................... 88

6.4.5 Radiation Stability.............................. 92

6.4 .6 Thermal Stability................................ 92

6.5 Advantages and Disadvantages.............................. 93

REFERENCES.

7. POLYESTER TYPE POLYMER SYSTEMS AS AGENIS FOR LOW-LEVEL WASTE

SOLIDIFICATION. . . . . . . . . . . . . . . . . . . . . . . . . . . . . . . .

7.1 Description of Polyester Type Resins.......................... 96

7.2 Additives............................................ 97

7.3 Solidification Processes Using Polyester Resins..................... 97

7.3.1 Vinyl Ester-Styrene (Dow Chemical Company) ................ 97

7.3.2 Water Extensible Polyester............................ 98

7.3 .3 Polymer Concrete.................................. 100

7.4 Waste Form Characteristics................................ 101

7.4.1 Chemical Compatibility............................ 101

7.4.2 Leachability.................................... 102

7.4.3 Mechanical Strength.............................. 106

7.4.4 Radiation Stability ............................... 107

7.4 .5 Thermal Effects.................................. 110

7.5 Advantages and Disadvantages.............................. 110

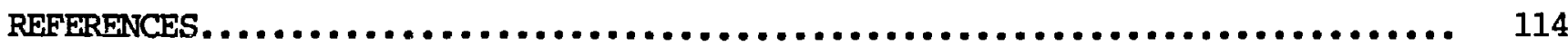

8. EPOXY AS AN AGENT FOR IOW-LEVEL WASTE SOLIDIFICATION. . . . . . . . . . . . . . . 115

8.1 Description of the Inert Carrier Process....................... 115

8.2 Waste Form Characteristics.............................. 117

8.3 Advantages and Disadvantages........................... 117 
REFERENCES.

9. MINERALIZATION PROCESSES FOR LON-LEVEL WASTE SOLIDIFICATION. 118

9.1 Description of Waste Bearing Minerals. 118

9.2 Solidification Using Mineralization Processes.

9.2.1 Clay Reaction Processes. 119

9.2.2 Silica Processes.

9.3 Mineralization Process Waste Form Characteristics. 122

9.3.1 Chenical Compatibility of Wastes. 124

9.3.2 Leachability. 124

9.4. Advantages and Disadvantages.

124

REFERENCES. 126

10. GLASS AS AN AGENT FOR LOW-LEVEL WASTE SOLIDIFICATION. 127

10.1 Solidification Processes Using Glass. 127

10.1.1 Slag Fusion Process. 127

10.1.2 Penberthy Pyro-Converter Process. 127

10.2 Glass Waste Form Characteristics.

10.2.1 Chemical Compatibility of Waste. 131

10.2.2 Leachability.

10.2.3 Mechanical Strength.

10.2.4 Radiation and Thermal Stability.

10.3 Advantages and Disadvantages. 
11. FCLYMER MODIFIED GYPSUM CEMENT (ENVIROSTONE) ..................... 135

11.1 Description of Envirostone.............................. 135

11.2 Waste Form Characterization.......................... 136

11.2 .1 Leachability................................. 136

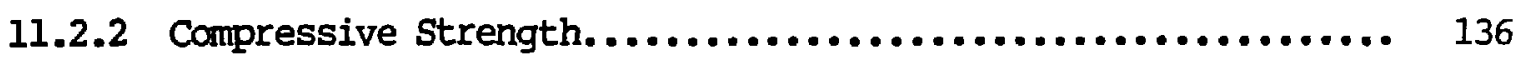

11.3 Advantages and Disadvantages........................... 137

REFERENCES.

12. POLYMER IMPREGNATED CONCREIE AS AN AGENT FOR LOW-LEVEL WASTE SOLIDIFICATION.

12.1 Description of Polymer Impregnated Concrete................. 138

12.2 Description of Polymer Impregnated Concrete.................. 138

12.3 Chemical Compatioility of the Wastes......................... 139

12.4 Waste Form Characteristics................................ 139

12.4 .1 Leachability...................................... 139

12.4 .2 Radiation Stability ........................... 142

12.5 Advantages and Disadvantages............................ 142

REFERFINCES. $\ldots \ldots \ldots \ldots \ldots \ldots \ldots \ldots \ldots \ldots \ldots \ldots \ldots \ldots \ldots \ldots \ldots \ldots \ldots \ldots \ldots \ldots \ldots \ldots \ldots \ldots \ldots$ 


\section{IIST OF TABLES}

Page

2.1 Sources and Types of Low-Level Radioartive Wastes.................. 6

2.2 Estimated 1980 Annual Low-Level Waste Generation Rates, by Source....... 8

2.3 Projected Low-Level Waste Generation Rates 1980-2000.............. 10

3.1 Composition of Portland Cements................................ 13

3.2 The Behavior of Principal Compounds Which Occur in Portland Cements..... 13

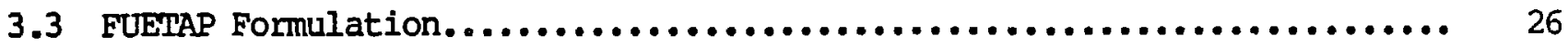

3.4 Chemical Compatibility of Wastes with Hydraulic Cements............... 29

3.5 Typical Strontium Leachabilities for Concrete Waste Forms.............. 34

3.6 Effect of Additives on Cesium Leachability $\ldots \ldots \ldots \ldots \ldots \ldots \ldots \ldots \ldots \ldots \ldots . . . \ldots$

3.7 Compressive Strength of Concrete Waste forms..................... 39

3.8 Observed Activity Levels for IWR Solidified Radwaste................. 41

3.9 Advantages and Disadvantages of Low-Level Waste Matrices -

Cenent.......................................................

4.1 Characteristics of a Typical Bitumen Useci for Radioactive

Solidification...............................................

4.2 Chemical Compatibility of Wastes with Bitumen..................... 62

4.3 Advantages and Disadvantages of Low-Level Waste Matrices Bitumen....................................................

6.1 Chemical Compatibility of Wastes with Urea-Formaldehyde..............

6.2 Advantages and Disadvantages of Low-Level Waste Matrices Urea-Formaldehyde..........................................

7.1 Advantages and Disadvantages of Low-Level Waste Matrices Vinyl Ester-Styrene - Dow Process..............................

7.2 Advantages and Disadvantages of Low-Level Waste Matrices Polyner Concrete..............................................

9.1 Comparison of Alternative Clay Fixation Processes...................

9.2 Advantages and Disadvantages of Low-Level Waste Matrices Mineralization Processes...................................... 


\section{IIST OF TABLES (OONME)}

Page

10.1 Advantages and Disadvantages of Low-Level Waste Matrices Glass.

12.1 Cesium and Strontium Leach Rates for Selected Cement and PIC Formulations. 


\section{IIST OE ETGURES}

Fiqure No.

Page

3.1 In-drum mixing processing for incorporating in cement............ 18

3.2 An overview of the Stock Equipment Campany systim, illustrating

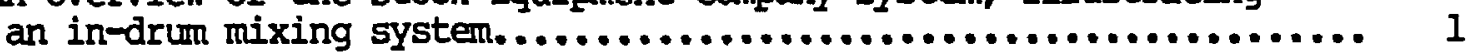

3.3 In-drum mixing assembly emploving a dual bladed mixer of Delaware Custon Materials............................................ 20

3.4 In-line mixing system with sodium silicate used as an additive (UNI Corporation).

3.5 CRN hydrofracture process.

3.6 Schematic of the PSU hot-pressed cement prucess.................. 26

3.7 Schematic of the FUEIAP process for high-level waste............. 26

3.8 Differences in Leachabilicy, from the same waste form, of ${ }^{90} \mathrm{Sr}$, ${ }^{137} \mathrm{Cs}$ and alpha enitters.

3.9 Effect of Additives on Cesium Ieachability.

3.10 Differences in leachability from indentical cement waste forms in various leachants.

3.11 Cumulative weight percent less than mesh size versus mesh size (microns) for impact testing of diatomaceous earth (slurry) waste/portland type II cement specimens as a function of $\mathrm{W} / \mathrm{C}$ ratio.

3.12 Cumulative radiation dose for BWR waste forms as a function of activity concentration.

3.13 Cumulative radiation dose for PWR waste forms as a function of activity concentration.

3.14 Pressurization from gamma radiolysis of concrete at $47^{\circ} \mathrm{C} \ldots \ldots . . . .$.

3.15 Effect of dose rate on steady state $\mathrm{H}_{2}$ pressure from gamma radiolysis of concrete. ........................................

4.1 Schematic of the stirred bitumen process.....................

4.2 Schematic of the termorary emulsion process....................

4.3 Schenatic of the sedimentation process....................... 
4.4 Schenatic of the screw extruder system........................

4.5 Leach rate curver for various constituents of a bitumen waste form......................................................

4.6 Leach rates from bitumen waste forms containing evaporator concentrates and $44 \%$ bitumen. 1 denotes mexphalt $40 / 30$ and 2 denotes mexphalt R 90/40

4.7 Leacr: Rate of ${ }^{137} \mathrm{Cs}$ from Bitumen BN-III containing:

1) $40 \%$ sodium nitrate, 2) $40 \%$ calcium nitrate and

$2^{\prime}$, 408 calcium carbonate.

5.1 Results of leaching polyethelene waste forms in Wacer:

a) $\mathrm{Na}$ from $40 \% \mathrm{NaBO}_{2}-60 \% \mathrm{DYDT}$, b) $\mathrm{Na}$ from $40 \% \mathrm{NaBO}_{2}-$

$60 \%$ DYLT and c) $\mathrm{Na}$ from $208 \mathrm{NaBO}_{2}-80 \%$ DYLT illustrating

differences in leaching from two types of polyethelene.............

6.1 Schematic of an in-line urea-formaldehyde system by UNI.

6.2 The 8 weight of free standing water is plotted against the ratio of water to UF............................................

6.3 Cumulative fraction releases for ${ }^{60} \mathrm{Co},{ }^{85} \mathrm{Sr}$ and ${ }^{137} \mathrm{Cs}$ from UF waste foms.............................................

6.4 Cumblative fraction release for ${ }^{85} \mathrm{Sr}$ with varying leachants.........

6.5 The effect of varying doses of ${ }^{60}$ Co irradiation of the leachability of $137 \mathrm{Cs}$. .

6.6 The effect of varying doses of ${ }^{60} \mathrm{Co}$ irradiation on the leachability of $90 \mathrm{Sr}$

6.7 Radiolytic gas evolved from a urea-formaldehyde waste form..........

6.8 Percentage of initial weight plotted against time for UF samples exposed to air.........................................

7.1 A schematic of the Dow process...............................

7.2 Fraction release of ${ }^{137} \mathrm{Cs}$ and ${ }^{60} \mathrm{Co}$ from evaporator sludge sciidified in vinyl ester-styrene.

7.3 Cumulative fraction release of Cs showing the effect of heating the waste form to $1000^{\circ} \mathrm{F}\left(538^{\circ} \mathrm{C}\right)$ for 10 minutes............

7.4 Fraction release of $\mathrm{NaNO}_{3}$ from a polymer concrete containing various additives. 


\section{LIST OF FIGURES (OONTE)}

Figure No.

Page

7.5 Fraction release of Cs from a polymer concrete with and without silica gel added to retain cesiuin.. $\ldots \ldots \ldots \ldots \ldots \ldots \ldots \ldots \ldots \ldots \ldots \ldots \ldots \ldots \ldots$

7.6 Fraction release as a function of irradiation dose............... 108

7.7 Compressive strength as a function of irridiation dose........... 109

7.8 Sample weight as a function of time for three samples at various water-to-binder ratios................................... 111

8.1 Schematic of the inert carrier process...................... 116

9.1 Flow charts for three processes: The rich clay process, the lean clay process and the clay calcination process................... 120

9.2 Fraction release from two minerals as a function of the kaolinite: salt ratio............................................. 125

10.1 A schematic of a portion of the slag fusion process.............. 128

10.2 The Penberthy kyro-converter glass system..................... 130

12.1 A schematic of a polymer impregnated concrete system............. 140 


\section{INIRODUCTION}

It is the purpose of this report to identify and review those agents and processes that can be employed for the solidification of low-level radicactive wastes. The scope of this survey includes not only those agents and processes that are currently used for low-level waste solidification, but also others that are either under development or proposed. In addition, agents and processes utilized for the solidification of other types of wastes, such as chemical toxic wastes and high-level radioactive wastes, were also considered. Information concerning the characteristics of solidification agents, solidification agent chemistry and applicability to specific waste streams, processing techniques, and waste form properties is summarized.

Solidification agents and processes applicable to low-level waste solidification must be capable of meeting existing requirements for waste forms; those that do not are excluded from further consideration. These requirements are considered in a subsequent section of this report. Some agents and processes are not included because associated costs and process complexity are so great as to preclude their general apolicability to low level wastes under existing conditions. In particular, some processes proposed for high-level waste fall into this category.

This survey is part of a program s:pported by the United States Department of Energy's Low-Level Waste Managenent Program (LIWMP). This work provides input into LIWMP efforts to develop and compile information relevant to the treatment and processing of low-level wastes and their disposal by shallow land burial. 


\section{BACKGROUND}

While a number of agents and processes have been used for the solidification of low-level wastes, operational difficulties have been observed for each of the systems under some conditions. Such difficulties include incompatibility with waste corstituents inhibiting solidification, free standing liquids, fires and premature setting. Some specific waste types have proven difficult to solidify with one or more of the contemporary agents. Modifications of agents and processes can improve solidification of such "problem" wastes. In addition, similar difficulties are anticipated for the solidification of "new" low-level waste streams which are generated using advanced volume reduction technologies. A review of existing information on the operation of sulidification agents and processes as well as past experience with specific waste types pramotes improved solidification practices.

\subsection{Puxpose of soliäification}

The purpcee of solidification is to convert liquic and wet solid wastes into a solid monolithic waste form. The licensing conditions of commercial shallow land burial disposal sites prohibit the disposal of liquids. Wastes containing liquids unust be solidified or at least dewatered. In addition, Federal (49 CFR 173) and various state regulations which gover? the transportation of liquid radioactive materials encourage solidification of liquid and wet solid wastes. The Nuclear Regulatory Conmissicn (NRC) has proposed licensing requirements for land disposal of radioactive waste (draft 10 CFR 61) which require that "liquid wastes, or wastes containing liquids, must be converted into a form that contains as little free standing 
noncorrosive liquid as is reasonably achievable, but in no case shall the liquid exceed 18 of the volume of the waste." This draft regulation also requires that the waste be structurally stable under expected disposal conditions where such stability may be achieved either by processing (solidifying) the waste to produce a stable form, or by placing the waste into a container or structuie that provides stability after disposal. These requirements are an extension of those included in the NRC Solid Waste Management Systens Standard Review Plan (NUREG-75/087, section 11.4) and Branch Technical Position EISB 11-3, "Design Guidance for Solid Radioactive Waste Management Systems Installed in Light-Water-Cooled Nuclear Power Reactor Plants."

The conversion of liquid and wet solid wastes into a stable monolithic form by solidification minimizes the potential for radionuclide release to the environment during interim storage, transportation and disposal. The solidifed waste form should be of such chenical, mechanical, radiolytic and thermal stability that its integrity can be assured over appropriate time intervals. Low leachability is desirable where leachability refers to the rencval of radionuclides from the waste form by fluids. In fact, leachability is perhaps the most important waste form property. Good mechanical properties are of significance especially during transportation, in order to reduce the probability of waste form fracture and breakage which may increase the rate of radionuclide release due to the increased surface area exposed to the environment. High thermal and radiolytic stability ensure that the waste form will retain its original properties over time and not pressurize the waste container. The waste form should also be chemically compatible with its container, although corrosion from the outside normally dictates container lifetime. Thermal stability refers primarily to waste form flammability and 
the effects of external fires occurring under accident conditions. In addition, economics dictate that process costs as well as the volume of the solidified waste forms produced should be as low as practicable.

\subsection{Lor-Level Radioactive Wastes}

\subsubsection{Sources and Tyces of Ion-Level Wastes}

The traditional definition of low-level radioactive waste (IIW) in the United States as set forth in the Low-Level Radioactive Waste Policy Act (PL 96-573) is that IIW is radioactive waste not classified as either highlevel radioactive waste, transuranic waste, spent nuclear fuel or uranium mill tailings. High-level radioactive waste (HIW) is defined in 10 CFR 50, Appendix $F$ as those aqueous wastes resulting from the operation of the first cycle sojlvent extraction system, ox equivalent, and the concentrated wastes from subsequent extraction cycles, or equivalent, in a facility for reprocessing irradiated reactor fuels. Transuranic waste (TRI) is material, excluding highlevel waste, which contains more than 10 nanocuries per gram of alpha enitting transuranic nuclides. As defined by the AEC (currently DOE) on the basis of half-life and specific radiotoxicity, the TRU waste classification includes all transuranic nuclides except Pu-238 and Pu-241 and, in addition, includes U233 and its daughter products (AEC Manual, Chapter 0511, 1973).

LIW is produced as a consequence of both federal government and ccmmercial operations. The federal government generates IIW from defense related activities (fuel fabrication, reactor operation, spent fuel storage, fuel reprocessing and associated chemical processing operations), facility decontamination and decomissioning, and research and development activities. Commercial generation of LWW results from both fuel cycle and non-fuel operations. Conmercial fuel-cycle operations include uranium mining, uranium milling, $\mathrm{UF}_{6}$ production, uranium enrichment, fuel fabrication, reactor operations, 
spent fuel storage and facility decontamination and decommissioning. (There is currently no fuel reprocessing conducted by the commercial sector.) These commercial fuel cycle activities are similar in nature to federal govermnent activities and hence, many of the wastes produced are analogous. Non-fuel operations, both institutional (including medical institutions and universities) and industrial (phanmaceutical and other industries) also produce IIW. The types of IIW produced by the various sources are summarized in Table 2.1. These wastes may be classified as either dry wastes or wet wastes. Dry wastes are solids and include items such as paper, glass, metal, wood, plastic, rubber and rags. Dry wastes may further be broken down into two classes: combustible or non-sombustible and compactible or non-compactible. Combustible dry wastes may be incinerated to rechuce volume. The resultant incinerator ash residue is highly dispersible and may require solidification prior to disposal. The majority of wet wastes are produced from the cleanup of aqueous process streams and waste streams prior to recycle or discharge. The type of waste resultant from these cleanup operations depends upon the process employed (filtration, ion exchange, evaporation, centrifugation, reverse osmosis, ultrafiltration, flocculation and sedimentation). Filtration produces filter cartridge and filter sludge wastes. Spent resin, powdered res:n sludges, and regenerant solution wastes result from ion exchange operations. Evaporation, centrifugation, reverse usmosis, ultrafiltration, flocculation and sedimentation processes concentrate waste products from aqueous streams to provide volume reduction and in so doing generate slurry, sludge and aqueous concentrate wastes. Reverse osmosis and uItrafiltration also produce membrane wastes. In addition, wastes resulting from cleanup operations are often subjected to additional treatment to reduce their volume for disposal. For spent resins and sludges this may include a dewatering operation (settling, centrifugation, or filtration) while volume reduction of aqueous 
Table 2.i Sources and Types of Low-Level Radioactive Hastes [1]

\begin{tabular}{|c|c|c|c|c|c|c|c|c|c|c|c|c|c|}
\hline \multirow[b]{4}{*}{ SOURCES } & \multicolumn{13}{|c|}{ IYPES OF HASIE GEMIERATED } \\
\hline & \multicolumn{4}{|c|}{ DRY HASTES } & \multicolumn{9}{|c|}{ NET MASTES } \\
\hline & \multicolumn{2}{|c|}{ COABUSTIBLE } & \multicolumn{2}{|c|}{ NONCOHBUSTIBLE } & \multirow{2}{*}{$\begin{array}{l}\text { FILTER } \\
\text { CAR- } \\
\text { TRI DGES }\end{array}$} & \multirow[b]{2}{*}{$\begin{array}{l}\text { SPENT } \\
\text { RESIMS }\end{array}$} & \multirow{2}{*}{$\begin{array}{c}\text { SLURRIES } \\
\text { AND } \\
\text { SLUDGES } \\
\end{array}$} & \multirow{2}{*}{$\begin{array}{l}\text { AQUEOUS } \\
\text { CONCEN- } \\
\text { TRATES }\end{array}$} & \multirow{2}{*}{$\begin{array}{l}\text { SPECIAL } \\
\text { ADUEOUS } \\
\text { SOLUTIONS } \\
\end{array}$} & \multirow{2}{*}{ OILS } & \multirow{2}{*}{$\begin{array}{c}\text { OTHER } \\
\text { ORGANIC } \\
\text { LIQUIDS } \\
\end{array}$} & \multirow[b]{2}{*}{ MENBRAHES ${ }^{b}$} & \multirow[b]{2}{*}{ BIOLOGICAL } \\
\hline & $\begin{array}{l}\text { COMPAC- } \\
\text { IIBLE }\end{array}$ & $\begin{array}{l}\text { MONCON- } \\
\text { PACTIBLE }\end{array}$ & $\begin{array}{l}\text { COMPAC- } \\
\text { IIBLE }\end{array}$ & $\begin{array}{l}\text { NONCON- } \\
\text { PACTIBLE }\end{array}$ & & & & & & & & & \\
\hline GOVERNMEHT OEFENSE & - & - & - & $\bullet$ & $\bullet$ & $\bullet$ & - & - & $\bullet$ & $\bullet$ & $\bullet$ & $\bullet$ & \\
\hline$D \& D^{C}$ & - & $\bullet$ & $\bullet$ & $\bullet$ & & $\bullet$ & & & - & & & & \\
\hline RD \& $D^{d}$ & $\bullet$ & $\bullet$ & - & - & . & $\bullet$ & $\bullet$ & - & $\bullet$ & - & - & - & $\bullet$ \\
\hline COAMERCIAL FUEL CYCLE MINING & - & $\bullet$ & - & - & & & $\bullet$ & $\bullet$ & & & & & \\
\hline MILLING & - & - & - & - & & & - & - & & & & & \\
\hline UfF $_{6}$ PRODUCTION & $\bullet$ & $\bullet$ & - & $\bullet$ & & & - & & & & & & \\
\hline ERIRI CIMENT & - & $\bullet$ & - & $\bullet$ & & . & - & & & $\bullet$ & $\bullet$ & & \\
\hline FUEL FABRICATION & $\bullet$ & $\bullet$ & - & $\bullet$ & & & - & & & - & & & \\
\hline PUNER PLANTS & $\bullet$ & $\bullet$ & $\bullet$ & $\bullet$ & $\bullet$ & $\bullet$ & $\bullet$ & $\bullet$ & $\bullet$ & $\bullet$ & & $\bullet$ & \\
\hline SPENT FUEL STORAGE & $\bullet$ & - & - & $\bullet$ & & - & $\bullet$ & & & & & & \\
\hline$D \& D$ & - & $\bullet$ & $\bullet$ & $\bullet$ & & $\bullet$ & & & $\bullet$ & & & & \\
\hline NOHFUEL CYCLE HEOICAL & - & & - & $\bullet$ & & & & & & & $\bullet$ & & $\bullet$ \\
\hline PIIARMACEUTICAL & $\bullet$ & & & - & & & & & & & $\bullet$ & & $\bullet$ \\
\hline INIVERSITIES & - & & $\bullet$ & - & & $\bullet$ & & & & & $\bullet$ & & $\bullet$ \\
\hline DTHER InDUSTRIES & $\bullet$ & & & $\bullet$ & & - & & & & & & & \\
\hline
\end{tabular}

a Decontamination, pickling, etching, electrepolishing, etc. solutions.

b Memhranes from processes such as ultrafiltration (UF) and reverse osmosis (RO).

c Decontantination and deconmissioning (D\&D) operations.

d Research, development, and demonstration (RD \& D) programs.

e Data on these wastes are incomplete and difficult to obtain. 
wastes is generally accomplished through some form of evaporation. Some wet wastes are combustible (resins, oils and organic liquids) and as such an incineration process could be employed to reduce waste volume. More detailed descriptions of these wastes and their origins can be found in the literature $[2.1-2.4]$ •

Because of the rapidly increasing cost is usposal by shallow land burial, there exists a strong incentive to decrease the volume of wastes produced. A number of advanceã volume reduction systens are rapidly gaining acceptance whish convert liquid and wet solid wastes to dry solids and high sidis content aqueous concentrates (e.g. calciners, thin film evaporators, and crystallizers) and convert solid and wet solid wastes to volume reduced solid wastes (e.g. incinerators). These volume reduced wastes will generally require solidification to either convert remaining liquids to solid forms or to minimize waste dispersibility by converting particulate solid wastes into monolithic waste forms.

\subsubsection{Generation Rates of Iow-Ievel Wastes}

A perspective of the major types of waste that require or may require solidification can be achieved by considering the generation rates of low-level wastes from their various sources and the projected increase in generation rates with time. The estimated annual generation rates of lowlevel wastes in the United States for 1980 are shown in Table 2.2 [2.5]. The majority of this waste (57\% by volume) originates fram commercial sources. LIW produced by the Federal government is not further broken dows. in Table $\mathbf{2 . 2}$ since this information is generally not available. Some 53\% of commercial IIW is generated by fuel cycle operations. Reactor (power plant) operations produce 828 of the volume of fuel cycle LIW. Non-fuel cycle wastes constitute 478 of cormercial IIW volume. The quantities of $\mathrm{LW}$ produced by institutional 
TABLE 2.2

ESTIMATED 1980 ANNUAL LOW-LEVEL WASTE GENERATION RATES BY SOURCE $[\bar{c} .5]$

Source

GOVERNMENT

COMMERCIAL (Fuel Cycle + Non-Fuel Sycle)

Fuel Cycle (Total)

$U_{6}$ Production

Enrichment

Fuel Fabrication

Reactor Operations

Non-Fuel Cycie (Total)

Institutiona ${ }^{(a)}$

Industria 1
Generation Rate, $m^{3} / y r$

$6.9 \times 10^{4}$

$9.3 \times 10^{4}$

$4.9 \times 10^{4}$

$1.6 \times 10^{3}$

$1.2 \times 10^{2}$

$7.0 \times 10^{3}$

$4.0 \times 10^{4}$

$4.4 \times 10^{4}$

$2.2 \times 10^{4}$

$2.2 \times 10^{4}$

(a) Hospitals, medical schools, colleges and universities. 
(hospitals, medical schools, colleges and universities) and industrial sources are estimated to be approximately equal [2.5]. Estimates of ILW generation through the year 2000 are listed by source in Table 2.3 [2.5]. Projections of the volume of fuel cycle ILW are based upon a proposed reference growth scenario projecting $180 \mathrm{GW}(e)$ of installed nuclear capacity by the year 2000 . While the generation rate of government $L L W$ is expected to remain approxinately constant over the period from 1980 to 2000, the volume of commercial LuW produced annually is projected to increase more than 1508 . (These projections do not consider governmental ifw resulting from the decontamination and decomnissioning of formerly utilized or surplus sites under the Formeriy Utilized Sites Remedial Action Program (FUSRAP) or the Surplus Facilities Management Program (SFMP). They also do not consider IIW resulting fram a possible resumption of commercial spent fuel reprocessing.) Most of this increase is due to increased quantities of fliel cycle wastes resulting from the expansion of installed power reactor capacity. The volume of fuel cycle LW is anticipated to increase by a factor of 3.5 between 1980 and 2000 while nor-fuel cycle waste will increase less than $60 \%$. The mix of fuel cycle wastes over this period may remain similar to that shown in Table 2.2 for 1980, however, reactor operations in particular have significant incentive to reduce waste volume. 
TABLE 2.3

PROJECTED LOW-LEVEL WASTE GENERATION RATES, 1980-2000 [2.5]

\begin{tabular}{|c|c|c|c|c|}
\hline \multirow[b]{2}{*}{ Year } & \multirow{2}{*}{$\frac{\text { Government, } \mathrm{m}^{3} / \mathrm{yr}}{\text { Total }}$} & \multicolumn{3}{|c|}{ Commercia $7, \mathrm{~m}^{3} / \mathrm{yr}$} \\
\hline & & Fuel Cycle & Non-Fiel Cycle & Total \\
\hline 1980 & $6.9 \times 10^{4}$ & $4.9 \times 10^{4}$ & $4.4 \times 10^{4}$ & $9.3 \times 10^{4}$ \\
\hline 1985 & $6.9 \times 10^{4}$ & $1.1 \times 10^{5}$ & $5.1 \times 10^{4}$ & $1.6 \times 10^{5}$ \\
\hline 1990 & $6.9 \times 10^{4}$ & $1.6 \times 10^{5}$ & $5.7 \times 10^{4}$ & $2.2 \times 10^{5}$ \\
\hline 1995 & $6.9 \times 10^{4}$ & $1.7 \times 10^{5}$ & $6.3 \times 10^{4}$ & $2.3 \times 10^{5}$ \\
\hline 2000 & $6.9 \times 10^{4}$ & $1.7 \times 10^{5}$ & $7.0 \times 10^{4}$ & $2.4 \times 10^{5}$ \\
\hline
\end{tabular}

REFERENCES FOR SECTION 2

2.1. Kibbey, A.H. and Godbee, H.W., A State-of-the-Art-Report on Iow-Ievel Radioactive Waste Treatment, ORWL/TM-7427, Oak Ridge National Laboratory, Oak Ridge, Tennessee, 1980.

2.2. Phillips, J., Feizollahi, F., Martineit, R., Bell, W. and Stouky, R., A Waste Inventory Report for Reactor and Fuel Fabrication Facility Waste, ONWI-20/NUS-3314, NUS Corporation, Rockville, Maryland, 1979.

2.3. Beck, T.J., Cooley, L.R, and McCampbell, M.R., Institutional Radioactive Wastes 1977, NUREG/CR-1137, University of Maryland, Baltimore, Maryland, 1979.

2.4. General Research Corporation, Study of Chemical Toxicity of Iow-Ievel Wastes, NUREG/CR-1973, General Research Corporation, Santa Barbara, California, 1980.

2.5. Oak Ridge National Iaboratory, Spent Fuel and Waste Inventories and Projections, ORO-778, Oak Ridge National Iaboratory, Oak Ridge, Tennesse 1980. 


\subsection{HYDRAULIC CEMENIS AS AGENIS FOR LOW-LEVVEL WASTE}

\section{SOLIDIFICATION}

Hydraulic cement was the original agent used for the solidification of low-level radioactive waste and it has remained in common use. The materials incorporated in cement waste forms generally consist of aqueous liquid wastes, and sludges. Recent developments in the use of hydraulic cements for waste disposal have evolved along three major lines. These are:

(1) The use of additives to adjust the properties of the cenent for specific wastes.

(2) Pressurized emplacement of a cementitious grout, bearing radioactive waste, into underground fracture zones.

(3) Pressing and sintering of cement containing waste to form a particularly stable monolithic waste form.

\subsection{Description of Hydraulic Cements}

Hydraulic cement is a generic term for a group of inorganic materials which, when mixed with water, form a "rigid interlocking matrix of hydration products which gradually replace the water between the coment grains and finally bind the composite cenent mass together" [3.1]

Hydraulic cements incorporate waste in two manners. Water in the waste combines chemically with cement constituents to form hydrated cement compounds although some water is also contained in the cement pore structure. Similarly, certain ionic sfacies in the waste may be incorporated into or adsorbed by cement hydration products. Other liquid wastes are held in the porosity of the cement matrix and some may actually interfere with the hydration process. Solids contained in wet wastes are mechanically held by 
the cement matrix. Large monolithic waste materials such as pipes, gloves, and failed equipment can be incorporated in cement not only to retain their associated activity but also to reduce dispersion and to provide shielding.

\subsection{Types of Hudraulic Cements}

Portland cement is produced by heating clay minerals at high temperatures $\left(1480^{\circ} \mathrm{C}\right)$ with lime. Typically the clay is derived from crushed slate or shale while the lime $(\mathrm{CaO})$ is the product of heating limestone $\left(\mathrm{CaCO}_{3}\right)$. In the proper proportions these minerals form a "clinker" which when cooled, mixed with gypsum $\left(\mathrm{CaSO}_{4} \cdot 2 \mathrm{H}_{2} \mathrm{O}\right)$ and pulverized is termed portland cement. By adjusting the proportions of raw materials, the quantities of major compounds comprising the cement are made to vary. This in turn affects such pruperties as strength, time of setting, generation of heat and resistance to shrinkage. Examples of specific cement formulations with well defined properties are portland cement types I-V. TYpe I portland cement is general purpose cement. Type II produces less heat, is slow setting and is sulphate resistant. Type III is a fast setting, high early strength cenent which generates significant heat during hydration. Type IV is slow setting with little heat generation. Type $\mathrm{V}$ cement is highly resistant to sulphate attack and suggested for marine use. Table 3.1 indicates the chemical analysis and compound composition of portland cements. The characteristics of the major cement compounds are listed in Table 3.2

The product of portland cement is largely an amorphous colloidal gel of calcium silicate hydrates resulting from the hydration of the major components of the cement. In portland cements these major components are dicalcium silicate $\left(2 \mathrm{CaO} \cdot \mathrm{SiO}_{2}\right)$, tricalcium silicate $\left(3 \mathrm{CaO} \cdot \mathrm{SiO}_{2}\right)$, tricalcium aluminate $\left(3 \mathrm{CaO} \cdot \mathrm{Al}_{2} \mathrm{O}_{3}\right)$, tetracalcium aluminoferrite $\left(4 \mathrm{CaO} \cdot \mathrm{Al}_{2} \mathrm{O}_{3} \cdot \mathrm{Fe}_{2} \mathrm{O}_{3}\right)$ and gypsum, 
TABLE 3.1

COMPOSITION OF PORTLAND CEMENTS [3.5]

\begin{tabular}{|c|c|c|c|c|c|c|c|c|c|}
\hline \multirow[b]{2}{*}{ 0xide Analysis, $q$} & \multicolumn{2}{|c|}{$\begin{array}{c}\text { Type I } \\
\text { Standard } \\
\end{array}$} & \multicolumn{2}{|c|}{$\begin{array}{c}\text { Type II } \\
\text { Moderate Heat }\end{array}$} & \multicolumn{2}{|c|}{$\begin{array}{l}\text { Type III } \\
\text { (I.E.S. }{ }^{\text {a) }} \\
\end{array}$} & \multicolumn{2}{|c|}{$\begin{array}{l}\text { Type IV } \\
\text { Low Heat }\end{array}$} & \multirow{3}{*}{$\begin{array}{l}\text { Type V } \\
\text { S:ll fate } \\
\text { Res. a) } \\
\text { Ave. } \\
64\end{array}$} \\
\hline & Range & Ave. & Range & Ave. & Range & Ave. & Range & Ave. & \\
\hline Lime $(\mathrm{CaO})$ & $66-62$ & 64 & $65-62$ & 63 & $67-63$ & 65 & $65-58$ & 60.5 & \\
\hline Silica $\left(\mathrm{SiO}_{2}\right)$ & $23-19$ & 21 & $24-20$ & 22 & $22-18$ & 20 & $26-22$ & 24 & 26 \\
\hline Aluraina $\left(\mathrm{Al}_{2} \mathrm{O}_{3}\right)$ & $8-5$ & 6.5 & $6-4$ & 5 & $7-4$ & 5.5 & $6-3$ & 5 & 2.5 \\
\hline Ferric Oxide $\left(\mathrm{Fe}_{2} \mathrm{O}_{3}\right)$ & $4-2$ & 2.5 & $6-3$ & 4 & $4-2$ & 3 & $6-2$ & 4.5 & 1.5 \\
\hline Magnesia ( $\mathrm{MgO})$ & $4-1$ & 2.5 & $4-2$ & 3 & $4-0.6$ & 2.3 & 4-1 & 3 & 2.5 \\
\hline Sul furic Anhydride $\left(\mathrm{SO}_{3}\right)$ & $2.5-1$ & 2.1 & $2-1$ & 1.5 & $3-2$ & 2.5 & $2-1$ & 1.7 & 2 \\
\hline Ignition loss & 2-0.6 & 1.3 & $2-1$ & 1.1 & $2-0.8$ & 1.5 & $2-1$ & 1.1 & 1.3 \\
\hline Insoluble residue & $0.08-0.01$ & 0.02 & $0.05-0.01$ & 0.02 & $0.07-0.01$ & 0.02 & $0.03-0.01$ & 0,02 & 0.02 \\
\hline Compound Composition & & & & & & & & & \\
\hline$c_{3} S$ & 48 & & 43 & & 57 & & 20 & & 39 \\
\hline$c_{2} s$ & 27 & & 30 & & 20 & & 52 & & 33 \\
\hline $\mathrm{C}_{3} \mathrm{~A}$ & 12 & & 7.5 & & 11 & & 6 & & 4.5 \\
\hline $\mathrm{C}_{4} \mathrm{AF}$ & 8 & & 12 & & 7 & & 14 & & 16 \\
\hline
\end{tabular}

(a) H.E.S. = High Early Strength; Res. = res istant.

(b) In cement terminology $C_{3}$ stands for tricalcium silicate, $C_{2} S$ for dicalcium silicate, $C_{3} A$ for tricalcium aluminate, and $\mathrm{C}_{4} \mathrm{AF}$ ior tetracalcium alumina ferrite.

TABLE 3.2

THE BEHAVIOR OF PRINCIPAL COMPOUNOS WHICH OCCUR IN PORTLAND CEMENTS [3.6]

RELATIVE BEHAVIOR OF EACH COMPOUND(a)

PROPERTYY

$$
c_{3} s
$$

$\mathrm{C}_{2} \mathrm{~S}$

$C_{3} A$

$\mathrm{C}_{4} \mathrm{AF}$

Rate of reaction

Medium slow Fast slow

Heat liberated, per unit of compound

Medium Small

Large

Small

Cementing value per unit of compound:

Early

Ultimate

Good

Good

Poor

Good

Good

Poor

Poor

Poor 
$\left(\mathrm{CaSO}_{4} \cdot 2 \mathrm{H}_{2} \mathrm{O}\right)$. The cement-water reaction is exothermic and occurs as a three step process. As setting and curing proceed, the hydrated minerals first form a colloidal "sol." This then forms a tobermorite "gel". The final curing process is characterized by the formation of a network of interconnected radiating, tubular fibrils which impart strength to the concrete [3.1-3.4]

Another major type of hydraulic cement with potential for use as a solidification agent is high-alumina cement (HAC). This material is primarily composed of monocalcium aluminate $\left(\mathrm{CaO} \cdot \mathrm{Al}_{2} \mathrm{O}_{3}\right)$ and obtains the bulk of its strength within twenty-four hours. This cement is highly resistant to attack by sulphate and sea water, however, under conditions of high temperature and humidity the strength of this material can decrease rapidly [3.2]. Highalumina cement is made by heating bauxite and limestone together and grinding the resultant clinker.

pozzolanic cement (I-P) is an interground mixture of pozzolana and portland cement clinker. Pozzolans ace any of a number of materials such as some volcanic tuff, fly ash, and burnt clay which when mixed with lime and water produce a cementitious material. Pozzolans are typically used to improve workability, reduce the heat of hydration, prevent calcium hydroxide bleeding and reduce attack from salts and sulfates. In radioactive waste forms, pozzolans may also reduce leachability. Pozzolana lime mortars used by the Romans in their constructions are still in place after 2000 years. Pozzolanic cement typically has a specific gravity of 2.3-2.6 compared to 3.1 for portland cement, and as such is 15-25\% lighter per unit volume [3.7].

Masonry cements consist of a mixture of portland cement, finely ground limestone or slaked lime and an additive to entrain air. These materials are designed for plasticity, improved water retention and reduced shrinkage 
$[3.2,3.7]$. It also is a more rapidly setting and curing cement which can be useful for the solidification of wastes containing chemicals which tend to retard or inhibit hydration.

\section{3 dditives}

A variety of materials have been used as additives in cement in order to better incorporate certain waste types or improve waste form properties. Many are specific clay minerals or materials which contain relatively large amounts of clay. The large absorptive and ion exchange capacities of these materials often suit them for use as fixatives for radionuclides. Other additive materials alter the characteristics of the wastes or the behavior of the cenent itself in order to allow incorporation of wastes which normally would hinder cement sclidification. Several additives are discussed below.

Crushed rock (bentonites) bearing clay minerals of the smecitite group, particularly the mineral montmorillonite, have been used as additives in cement systems. These minerals have relatively high cation exchange capacities making them potentially useful as ion sorbers. Smectites also tend to swell significantly when wet, taking up large volumes of water.

Research at Oak Ridge National Laboratory (ORNL) has lead to the use of various materials as additives in their hydrofracture grout [3.8]. Among these are grundite (a trade name of a cormercial clay product of the illite group), Attapulgite-150 (a drilling clay product of the polygorskite group which reduces phase separation of the grout mixture), crushed Conasauga shale and brick dust. These materials are primarily intended to reduce cesium leachability [3.9]. Experiments conducted by Delaware Custam Material Inc. suggest that Conasauga shale added to cement waste forms provides better cesium retention (by a factor of 100) than do either Na-bentonite or Ca-bentonite 
[3.10]. Among the additives tested at Savannah River Laboratory are the clay mineral vermiculite, the natural zeolite clinoptilolite and synthetic zeolites [3.11].

Sodium silicate is an additive employed by some manufacturers of solidification systens. This material is reported to increase the waste packing efficiency in cement by as much as 758 , increase the liquid tolerence of cement and improve the characteristics of the solid in the presence of wastes bearing borate solutions [3.2]. The process involves the immobilization of multi ylent metal ions in a precipitated gel. Unhindered by the gel, the ions would normally tend to interact with the hydration products and potentially inhibit the development of cement.

Sulfonated napthalene wix nielamine formaldehyde condensates have been added to cement as plasticizers. These materials reduce the volume of water necessary to produce a solid waste form of high density [3.12]. •

Some substances when added to cement mixtures act to inhibit setting. While normally this effect is detrimental, in some cases this action can be beneficial. For instance sugar, specifically in the form of delta gluconolactone, has been used to prolong setting times in the ORNL hydrofracture grout until after the grout has been placed [3.8]. Excess water may also be used to slow the setting process, but this method also tends to significantly weaken the end product [3.7]. Certain types of waste, speciffically those bearing nitrates and borate are known to inhibit setting and can, if present in sufficient quantities, prevent cement from adequately solidifying [3.3]. Temperature and humidity have significant influences on set time and the strength of the product and must be controlled to optimize strengich.

Certain other substances are known to promote the setting of cement. Calcium chloride (2-3 wto) is commonly used as an accelerator as are aqueous 
solutions of alkali salts such as hydroxides, carbonates, aluminates and silicates [3.7]. In cases where acidic wastes are incorporated in cements, NaOH or lime is often addeã in order to maintain the necessary high pH (10-12) required for the cement-waste mixture to set and produce optimum waste form properties.

\subsection{Solidification Processes Using Hydraulic Cements}

Incorporation of radioactive waste in cement can be achieved in a variety of ways. Important considerations include: cement handling techniques, mixing methods, and equipment complexity and maintainability. Cenent processing options are differentiated primarily by the method in which cement and waste are mixed. Recently developed and developing techniques innose srecific pressure and temperature conditions. Cement waste solidification processes are discussed below.

\subsubsection{Drum Mixing}

Figure 3.1 illustrates an in-drum mixing process developed by the Stock Equipment Company. Dry cement and a disposable mixing weight are placed in a 55-gallon drum outside of the shielded waste processing area. The drum is moved behind the shielding wall where the waste and any additional chemicals are adcred. The drum is then remotely capped and tumbled end-over-end in order to thoroughly mix the contents. An overview of the process indicating each of the individual process steps is shown in Figure 3.2.

Another form of in-drum mixing is employed by Delaware Custom Material, Inc. In their system, disposable rotor blades are turned within a 55 gallon drum by a pneumatic notor as the cement and waste are added (Figure 3.3). Hittman Nuclear and Development Corporation uses liners of betweer 70 and 170 cubic feet in volume for their in-container solidification systems. 


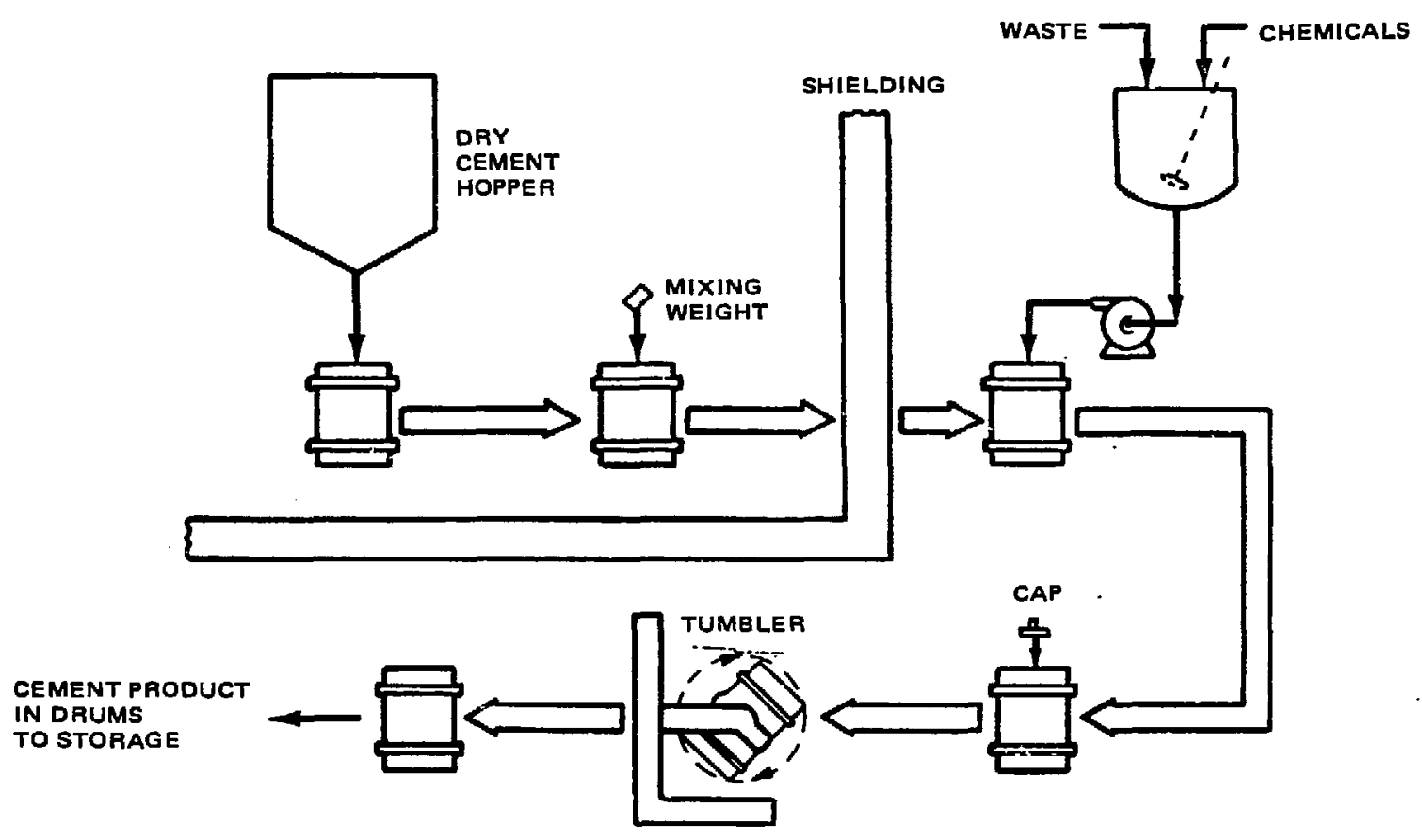

Figure 3.1. In-drum mixing processing for incorporating LLW in cement. 


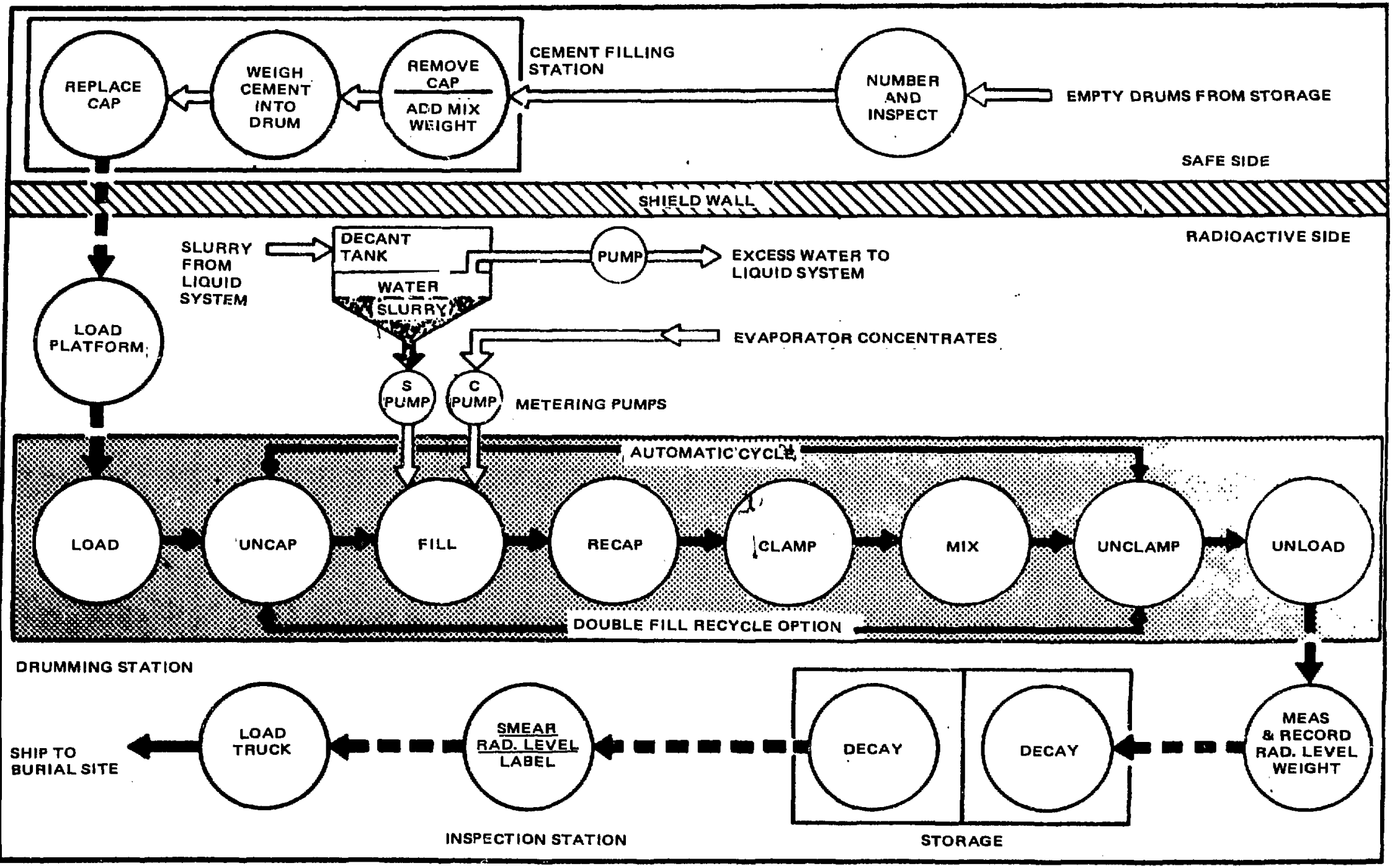

Figure 3.2. An overview of the Stock Equipment Company system, illustrating an in-drum mixing system. 


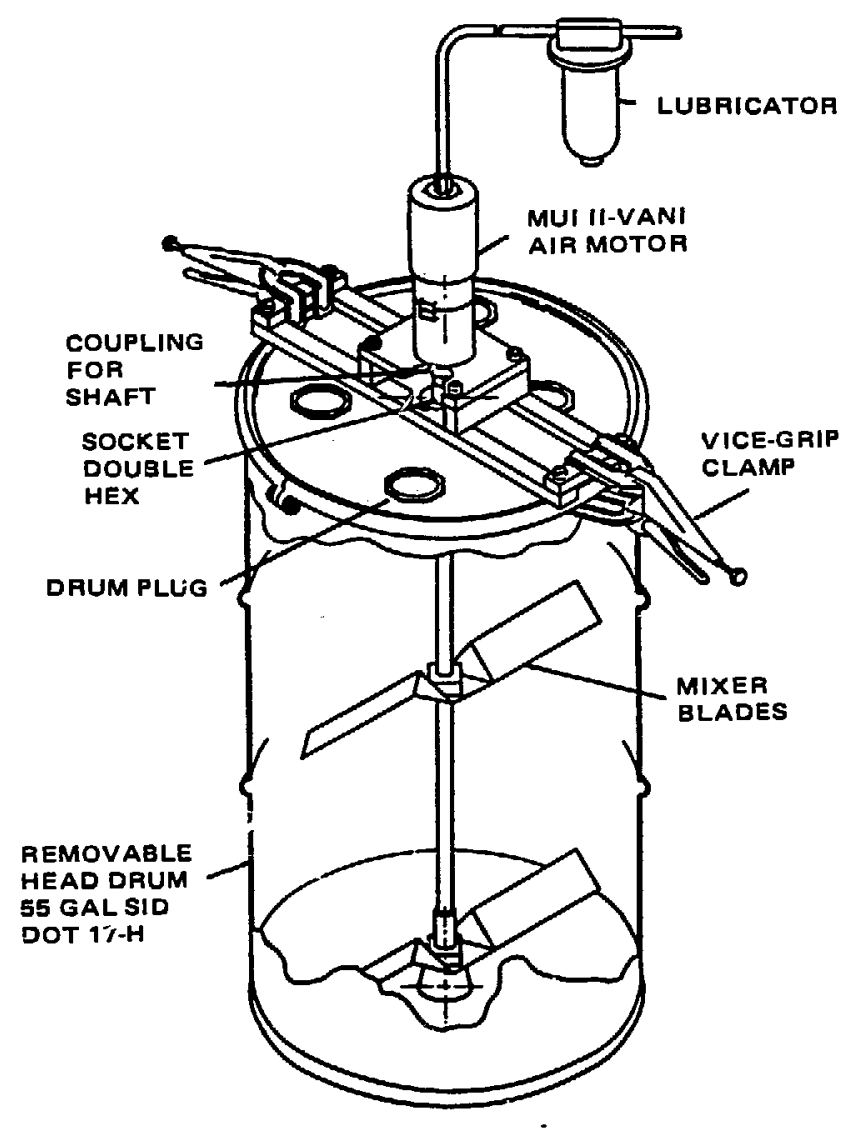

Figure 3.3. In-drum mixing assembly employing a dual bladed mixer of Delaware Custom Materials. 
These liners are placed into shielded shipping casks after which waste and then cement are pumped into the liner through an assembly which contains the fill ports, the drive mechanism for the disposable rotor, and ultimately seals the liner.

The waste forms produced at Brookhaven Nlational Laboratory incorporate low-level radioactive waste in a mixture of portland cement and vermiculite. Wastes solidified in this manner include liquid evaporator slurries, compacted trash and 55-gallon drums containing ion exchange resins. Cement and vermiculite (and large solid wastes, if any) are placed into the steel reinforced, precast concrete casks ( $15 \mathrm{~cm}$ thick walls, $4.5 \mathrm{~m}^{3}$ capacity). Liquid waste is pumped into the cask through pipes enbedded in the dry cement, with the vermiculite serving as a sorbent and water distribution agent. When the surface of the vemiculite and cement mixture appears moist, pumping is stopped. A steel reinforcing grid is placed on top of the cask and prenixed uncontaminated concrete is poured as a seal. In a typical cask, $0.9 \mathrm{~m}^{3}$ of concrete are used to solidify $1.25 \mathrm{~m}^{3}$ liquid waste [3.13].

\subsubsection{In Line Mixing}

In-line mixing processes combine the waste, any additives, water and cement before they are placed into the disposal container. Ribbon mixers and pug mills, among others, may be used to mix the waste and cement. Vendors of in-line cement solidification systems include: Atcor, Inc., Hittman Nuclear and Development Corporation and United Nuclear Industries, Inc. [3.14] . Figure 3.4 illustrates the United Nuclear Industries, Inc. in-line system which, in concept, is similar to most other in-line systems. Here preconditioned waste, adjusted for moisture content and $\mathrm{pH}$, and the cenent are blended at a mixing pump. Additives (if any) can be introduced at the fillport. 


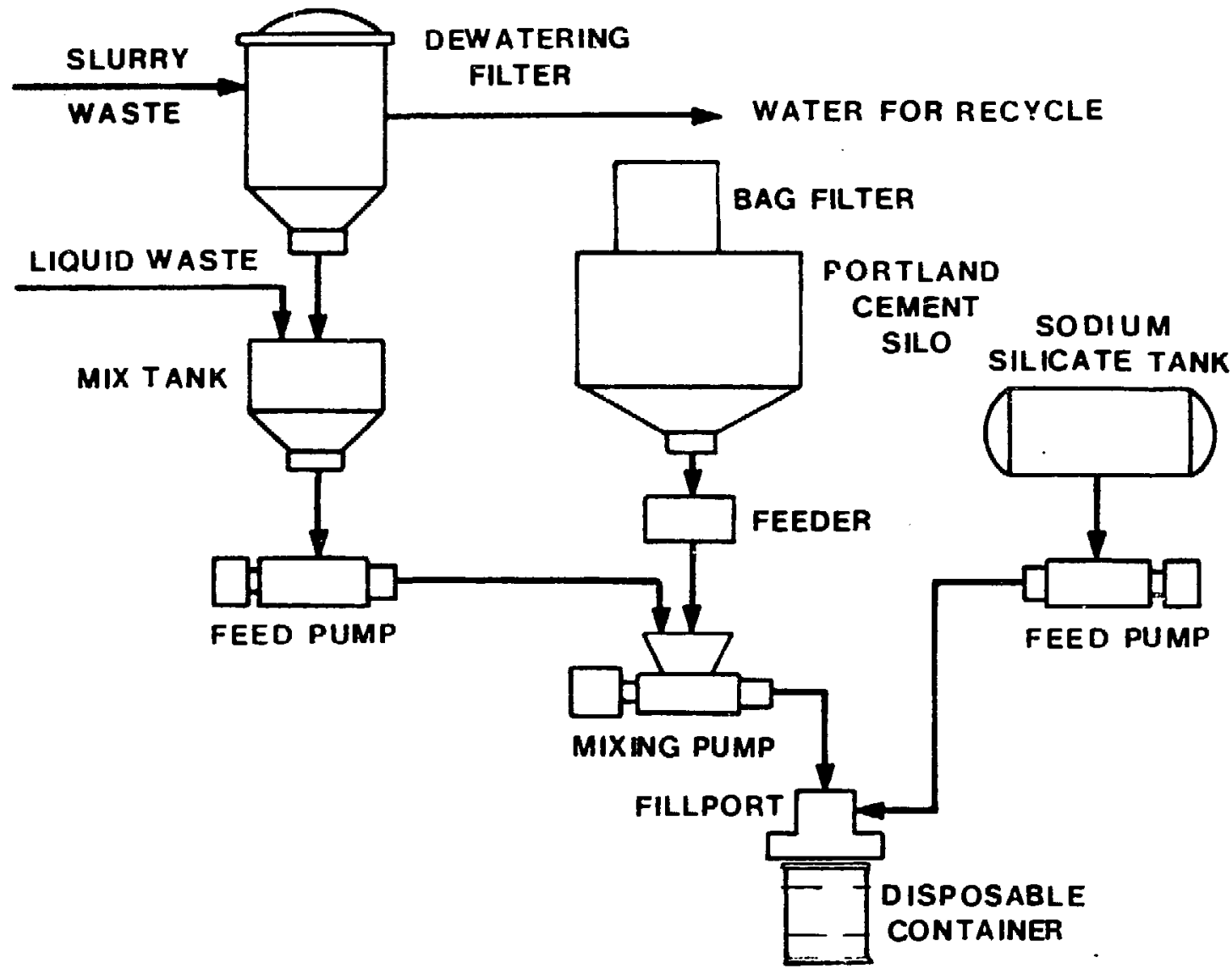

Figure 3.4. In-line mixing system with sodium silicate used as an additive (UNI Corporation). 


\subsubsection{Cementitious Grouts}

Since 1966 Oak Ridge National Laboratory (ORNL) has been disposing of waste by the hydrofracture grout method developed there. This process, illustrated in Figure 3.5, involves pumping a premixed grout of cementitious material and waste into beds of Conasauga shale some $800-1000$ feet underground. The pressure under which the fluid is pumped acts to fracture the shale allowing the grout to penetrate along the horizontal bedding planes of the shale in layers about $1 / 2^{n}$ thick. More than two million gallons (by 1978) of waste solution have been injected containing a total activity of 600,000 curies [3.15] •

The grout is composed of neutralized waste solution which is blended with predetemined weights of dry cement solids consisting of cement, fly ash, clay minerals (to increase adsorption and tu reduce phase separation) and delta gluconolactane (a sugar) which retards the setting time of the grout. Similar mixtures of material can also be use to solidify low and intermediatelevel wastes in drums [3.16].

\subsubsection{Hot Pressed Cements}

A process of hot pressing cement at elevated pressures and temperatures has been developed at Pennsylvania State University (PSU) [3.17]. Various types of portland cements (I, III and V) as well as other varieties of hydraulic cements have been shown to develop unusually high strength (ten times that of nomal cements) and high density with very low porosity and permeability under hot pressing. This makes the product particularly well suited for the retention of radionuclides in the waste. Processing temperatures of $100^{\circ} \mathrm{C}$ to $300^{\circ} \mathrm{C}$ and pressures of 25,000 to 100,000 psi are used. 


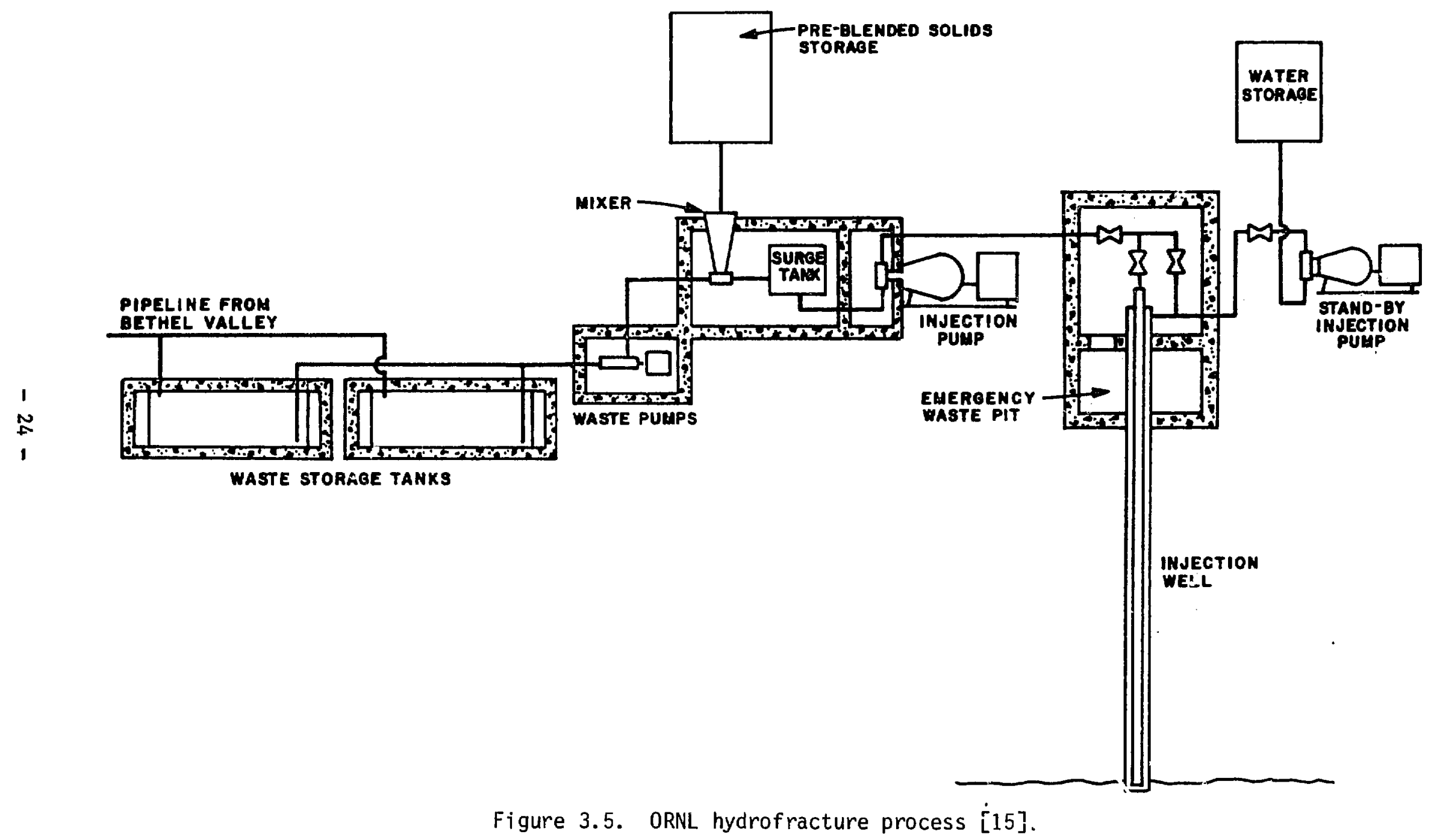


In general, calcium aluminate cement was found to develop a better product than portland cement [3.17]. A flow chart for this process - provided as Figure 3.6. The addition of a hot-pressing step does introduce a significant process complexity.

Encapsulation of a hot-pressed waste pellet by an additional layer of hot-pressed calcium-aluminate cement was found to provide the best performances. Mixing of calcineä waste with cement and hot-pressing the mixture was satisfactory while uncalcined waste mixed with cement extruded a paste containing $\mathrm{NaNO}_{3}$ and formed cracked samples. Leaching tests generally resulted in small weight gains and volume increases caused by additional hydration of the cement. Hot-pressed portland cement showed high resistance to leaching in 1:1 $\mathrm{HCl}$. Hot pressed calcium aluminate cenent mixed with waste showed resistance for several hours while standard calcium aluminate and portland cements disintegrated quickly [3.17].

\subsubsection{EUETAP}

Following the lead of the Pennslyvania State University group and their own research with concrete waste forms, a group at ORNL developed the FUETAP (Formed Under Elevated Temperature and Pressure) process [3.18]. Cementitious materials, additives and calcined wastes, (Table 3.3) are mixed and poured into a sealed container. Heating to temperatures as $10 \mathrm{w}$ as $100^{\circ} \mathrm{C}$ with pressures of $0.1 \mathrm{MPa}$ ( $15 \mathrm{psi}$ ) for 24 hours produce a good product. The process was developed for high-level waste, therefore, if there is sufficient activity in the waste the self-heating alone can provide an adequate temperature. Adcitional steps to vent unbound water are necessary to prevent subsequent container pressurization. Consequently, there is very little pressure or gas generated due to radiolysis of water in the concrete. Loading of waste is reiatively low (12\%). Figure 3.7 presents a flow chart of the FUETAP process [3.18] • 
Table 3.3

FUETAP Formulation [3.18]

\section{Ingredient}

Cement (Portland I)

Fiy Ash

Clay

Simulated Waste Solids

Sand

$\mathrm{NO}_{3}$

Water wt $\%$

22.

11.

7.5

15.0

27.75

0.75

16.0

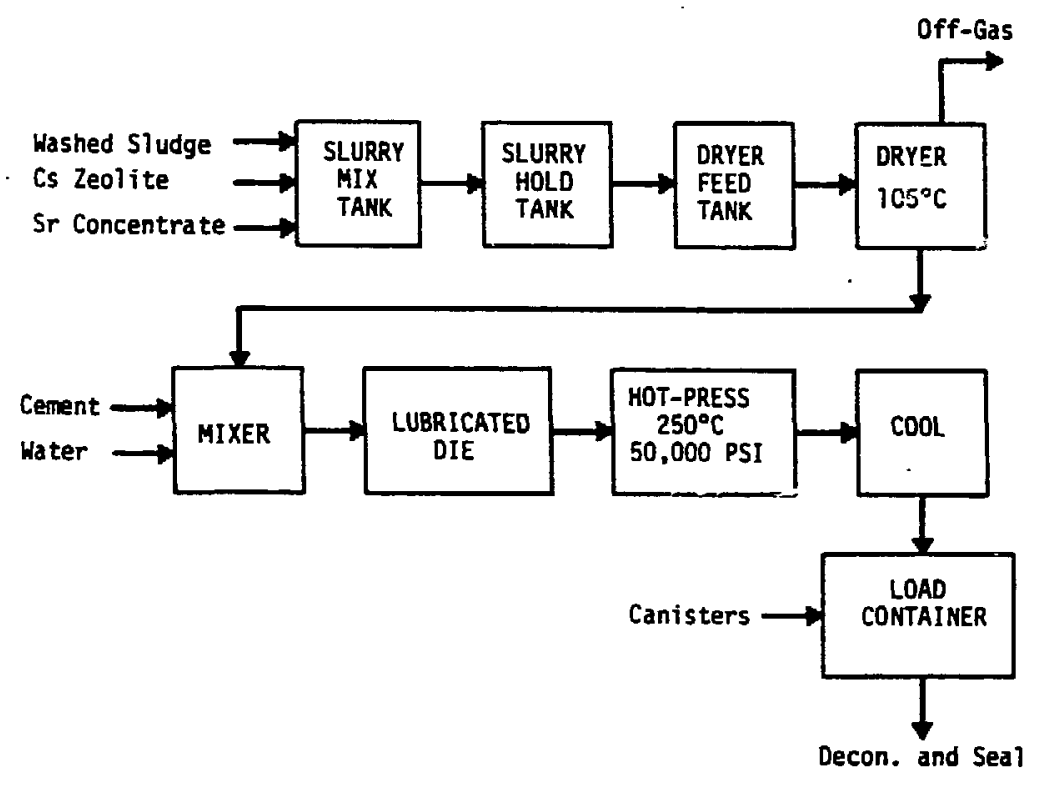

Figure 3.6. Schematic of the PSU hot-pressed cement process.

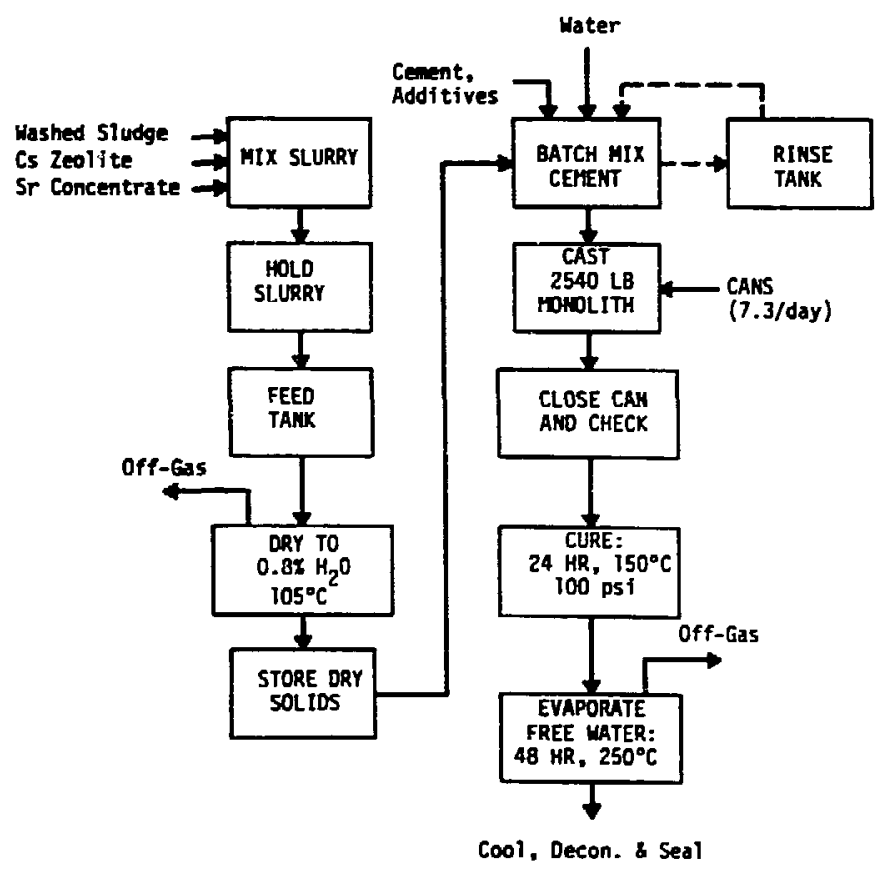

Figure 3.7. Schematic of the FUETAP process for the solidification of high-level waste. 


\subsection{6 cold Pressed Cements}

The cold pressing process developed at Mound Laboratory incorporates transuranic contaminated incinerator waste in either portland type I or.high alumina cement. The ash and cement are formed into pellets at pressures of 25,000 psi. The low water content ( 3 wtz) and high loading ratio (65 wtz) do not adversely affect the waste form [3.19].

\subsubsection{Surface Treatments}

There are a wide variety of surface treatments for cement that can be used to provide a waterproof coating or a surface which is resistant to chemical attack. A brief list is given here while a more complete general discussion can be found in the literature [3.7]. Some of these materials are:

(1) Sodium silicate, magnesium silico-fluoride, zinc silico-fluoride (surface hardeners)

(2) Linseed, tung or mineral oil

(3) Various paints \& lacquers (e.g. bituminous or coal tar paints)

(4) Epoxy-ester paints

(5) Bituminous pastes and emulsions

(6) Hot coal tar

(7) Coal tar epoxy

(8) Various two part resins

(9) $\mathrm{SiF}_{4}$ gas treatment of precast concrete

The last two processes have received some attention relative to radioactive waste djsposal. The silicon fluoride treatment is known as the Ocrate process and produces a coating of hydrated silica, alumina and calcium fluoride which is resistant to many agents [3.7]. This process has been mentioned as a possible means of decreasing permeability and porosity in 
FUETAP concretes [3.18]. Impregnating cement with monomer resins has been explored at Brookhaven National Laboratory. This process is discussed in a later section.

\subsection{Waste Form Characteristics}

Eydraulic cements, as illustrated in the previous sections, are available in a wide range of compositions and can be implemented using several processes. By manipulating the mixture of cement, waste and additives and controlling the environment in which the waste forms are produced and cured, the characteristics of the solidified waste form may be significantly altered. of all waste form materials, cement has perhaps the greatest adaptability in the sense that it can easily be "tailored" for specific uses.

\subsubsection{Chemical compatibility of Wastes}

The properties of the waste form are often highly dependent upon the nature and amount of the waste incorporated in the cement waste form. Consideration of the chemical compatibility of the waste with the solidification agent usually refers to the ability to produce a product meeting existing regulatory criteria which require the waste form to be a free-standing monolithic solid with no free-standing water. Table 3.4 generally indicates the chemical compatibility of typical wastes with hydraulic cements. Some wastes for which poor compatibility is indicated can readily be incorporated in small quantities in cement waste forms. Specific wastes within each typical waste type can be difficult to solidify even if good compatibility is indicated, dependent upon the chemical corposition of the specific waste, and the quantity of waste one attempts to incorporate in the waste forms. 
Tab7e 3.4

Chemical Compatibility of Wastes with Hydraulic Cements

Waste Type

Ion exchange

STudges

Boric acid wastes

Sulfate wastes

Nitrate wastes

Phosphate wastes

Carbonate wastes

Detergent solutions

Complexing agent wastes

0i1s

Organic liquids

Acidic wastes

Alkaline wastes

Filter cartridges

Large items
Waste Compatibility

$$
\begin{gathered}
\text { poor - good }(a) \\
\text { good } \\
\text { poor - good }(b) \\
\text { fair } \\
\text { good } \\
\text { good } \\
\text { good } \\
\text { poor } \\
\text { poor } \\
\text { poor } \\
\text { poor } \\
\text { poor - good }(c) \\
\text { good } \\
\text { good } \\
\text { good }
\end{gathered}
$$

\footnotetext{
(a) dependent upon resin type and form, waste loading and water/cement ratio.

(b) good with additives

(c) poor for highly acidic wastes, good with additives
} 
While ion exchange resins can be successfully solidified with cement, instances have been observed in which waste form swelling occurs which produces a waste form with extremely low integrity $[3.3,3.4,3.20]$. This behavior has been shown to be dependent upon the resin type, resin loading, the waste loading in the cement and the water/cement ratio. It is postulated to result from resin swelling and shrinking in the waste form because of competition between the cement and resin for water during solidification, adsorption of soluble cement constituents by the resin and/or subsequent resin sorption of water from the environment.

Boric acid acts as a retarder for cement setting and curing. When present in sufficient quantities and concentrations, it can prevent the cement fram solidifiying. Additives, such as lime, can modify the chemical form of the boric acid and the pH of the waste sufficiently to promote satisfactory incorporation in cement. The problem is also minimized by selection of an optimal cement type for solidification.

Detergent wastes, oils and organic liquids are difficult to solidify with cement, primarily because they tend to prevent the interaction of the dry cement powder with the water required for hydration. When present in low concentrations in the waste, these materials can be solidified with cement. Some success has been achieved for the solidification of organic solvents which are immiscible with water by mixing with cement under high shear conditions [3.3].

Acidic wastes can be difficult to solidify if the $\mathrm{pH}$ of the waste is low. Cement is a highly alkaline medium and solidification requires a wastecement mixture to have an alkaline pH. While cement is quite effective in raising the $\mathrm{pH}$ of most wastes, its ability to do so is limited, particularly with highly acidic wastes. In addition, the reaction between highly acidic 
wastes and cement tends to be violent. Acidic wastes are typically solidified after pretreatment to neutralize the waste. Some cement types and/or cements with additives are better suited than others for the solidification of acidic wastes.

\subsubsection{Leachability}

The leachability of cementitious waste forms varies significantly depending on waste loading, waste type, cement type and the additives (if any) employed. The transport process is often dependent in part on the radionuclides in question, their ionic characteristics and their interactions with the waste form. Therefore, there are significant differences in the rates of leaching among the various radionuclides from the same waste form. For example, the plutonium leach rate from a cement waste form for a time interval of 1008 hours was $0.97 \times 10^{-7} \mathrm{~g} /\left(\mathrm{cm}^{2}\right)$ (d). A similar test for strontium, over 1008 hours, gave a toizal leachability of $0.20 \times 10^{-3} \mathrm{~g} /\left(\mathrm{cm}^{2}\right)(d)$ [3.21]. Figure 3.8 illustrates the differences in the leachability of ${ }^{90} \mathrm{Sr},{ }^{137} \mathrm{Cs}$ and alpha emitters from a cement waste form [3.21]. While the waste used here is a low heat generating sludge from a reprocessing operation which is not representative of commercially generated waste, it does indicate that varying the waste content can significantly affect leachability. Similarly, in Table 3.5 three types of waste from the Savannah River Plant are shown to cause significart differences in strontium leachability [3.21].

Incorporation of various additive materials, such as cesium sorbants, has significant effect on the leachability of that element. The use of local materials such as crushed shale, pottery clay and grundite was investigated at Oak Ridge National Laboratory in their hydrofracture grout [3.8]. Results as shown in Figure 3.9 indicate significant differences in the relative abilities of these materials to retain cesium. Investigations of the effects of other 


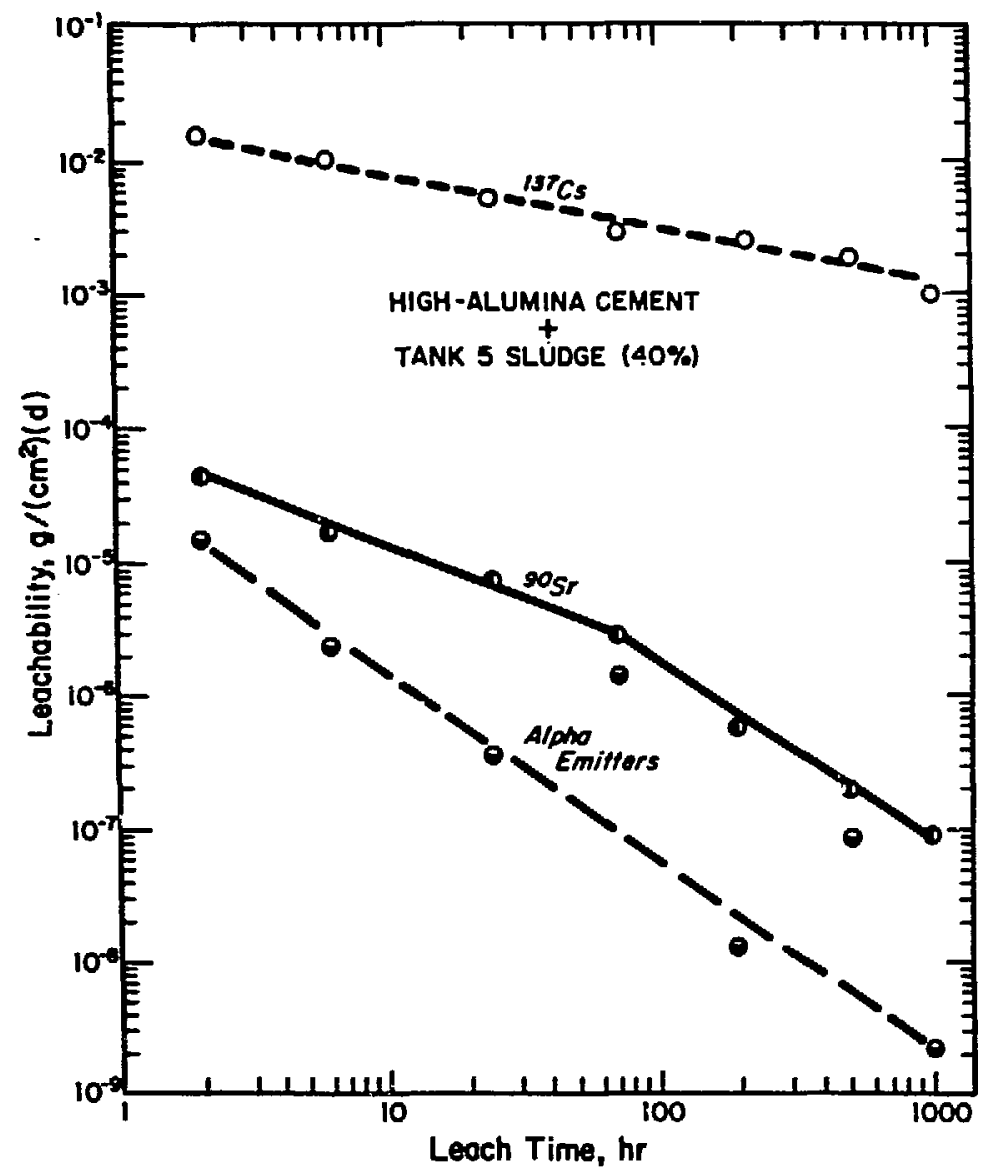

Figure 3.8. Differences in leachability, from the same waste form, of ${ }^{90} \mathrm{Sr},{ }^{137} \mathrm{Cs}_{\mathrm{s}}$ and alpha emitters. 


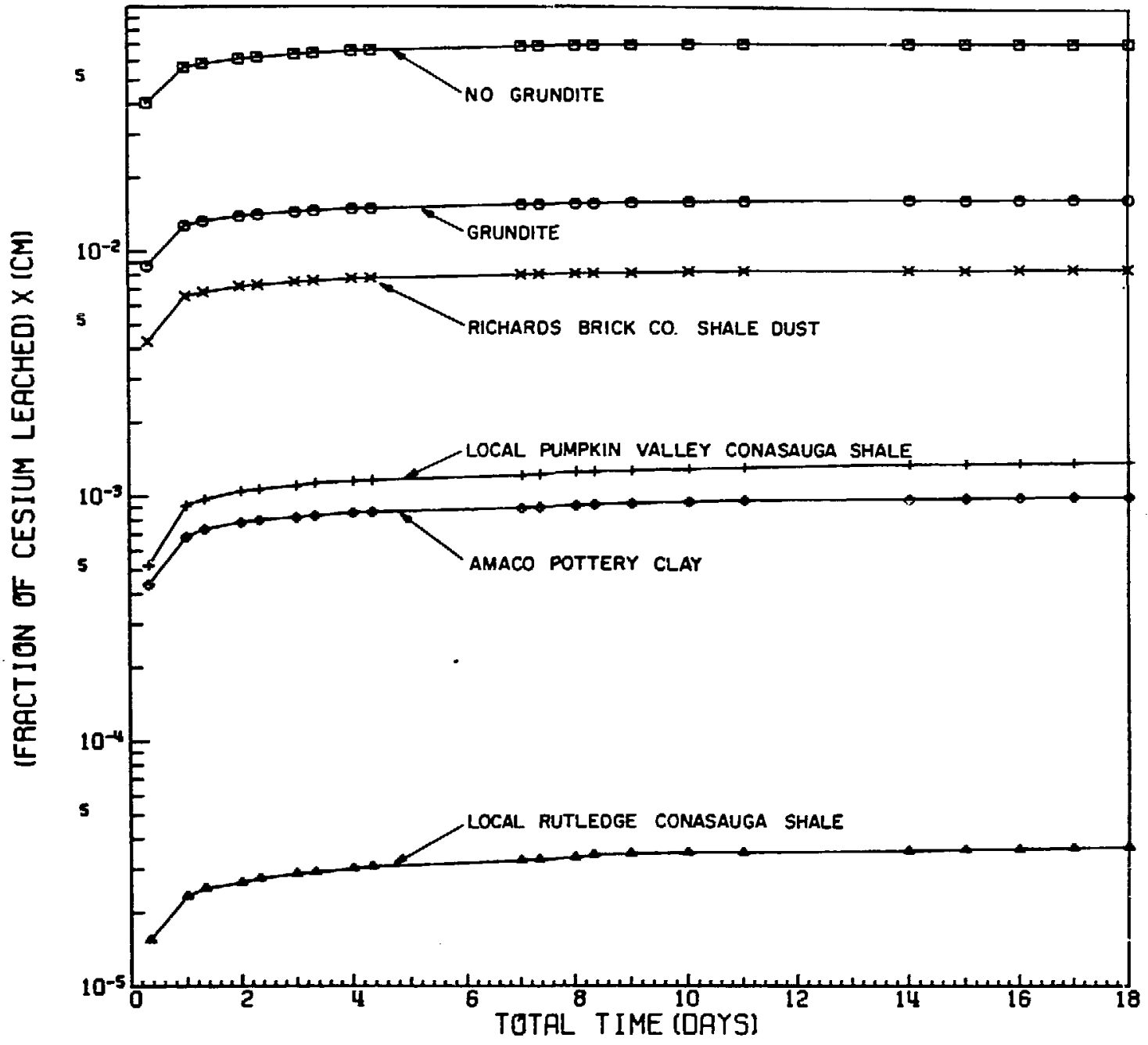

Figure 3.9. Effect of additives on cesium leachability [3.8]. 
Table 3.5

TYpical Strontium Leachabilities for Concrete Waste Forms [3.21]

\begin{tabular}{|c|c|c|c|c|c|c|c|}
\hline \multirow{3}{*}{$\begin{array}{l}\text { Time, hr } \\
2^{c}\end{array}$} & \multirow{3}{*}{$\begin{array}{c}\text { Sludge }^{\mathrm{a}} \\
\text { Content, } 8 \\
0 \\
10 \\
25 \\
40\end{array}$} & \multicolumn{2}{|c|}{ Sr Leachability, } & \multicolumn{2}{|c|}{$10^{-2} \mathrm{~g} /\left(\mathrm{cm}^{2}\right)(\mathrm{d}), \mathrm{f}$} & \multicolumn{2}{|c|}{ Cement Types } \\
\hline & & I & II & III & $\mathbf{V}$ & $\mathrm{I}-\mathrm{P}$ & HAC \\
\hline & & $\begin{array}{l}2.7 \\
2.5 \\
3.3 \\
2.2\end{array}$ & $\begin{array}{r}12.0 \\
7.6 \\
4.6 \\
2.8\end{array}$ & $\begin{array}{l}5.0 \\
4.7 \\
2.5 \\
2.7\end{array}$ & $\begin{array}{l}3.4 \\
2.4 \\
2.7 \\
1.6\end{array}$ & $\begin{array}{l}3.6 \\
2.7 \\
2.1 \\
2.5\end{array}$ & $\begin{array}{l}9.1 \\
6.6 \\
5.8 \\
5.3\end{array}$ \\
\hline $72^{c}$ & $\begin{array}{r}0 \\
10 \\
25 \\
40\end{array}$ & $\begin{array}{l}1.5 \\
0.73 \\
0.63 \\
0.37\end{array}$ & $\begin{array}{l}1.2 \\
1.1 \\
0.83 \\
0.82\end{array}$ & $\begin{array}{l}1.4 \\
1.2 \\
0.72 \\
0.56\end{array}$ & $\begin{array}{l}1.4 \\
1.2 \\
1.1 \\
0.52\end{array}$ & $\begin{array}{l}1.5 \\
0.79 \\
0.53 \\
0.24\end{array}$ & $\begin{array}{l}1.5 \\
1.0 \\
0.48 \\
0.22\end{array}$ \\
\hline $1008^{c}$ & $\begin{array}{r}0 \\
10 \\
25 \\
40\end{array}$ & $\begin{array}{l}0.25 \\
0.16 \\
0.13 \\
0.079\end{array}$ & $\begin{array}{l}0.24 \\
0.22 \\
0.11 \\
0.098\end{array}$ & $\begin{array}{l}0.14 \\
0.13 \\
0.15 \\
0.11\end{array}$ & $\begin{array}{l}0.18 \\
0.17 \\
0.11 \\
0.13\end{array}$ & $\begin{array}{l}0.16 \\
0.13 \\
0.093 \\
0.054\end{array}$ & $\begin{array}{l}0.23 \\
0.13 \\
0.041 \\
0.024\end{array}$ \\
\hline
\end{tabular}

a. Sludge III: $508 \mathrm{Fe}\left(\mathrm{OH}_{3}\right), 508 \mathrm{MnO}_{2}$ in mole 8

b. Each entry is the average of six measurements

c. Error factor E (958 confidence) : at $2 \mathrm{hr}, \mathrm{E}=1.24$; at $72 \mathrm{hr}, \mathrm{E}=1.49$, at $1008 \mathrm{hr} . \mathrm{E}=1.40$.

additives such as synthetic zeolites on cesium retention have been conducted at Savannah River Laboratory with high-alumina cement and pozzolanic cement [3.11]. These resuits as shown in Table 3.6 indicate differences in retention abilities for these additives.

A significant factor in leachability studies is the type of leachant used. Ixperiments at Brookhaven National Laboratory were designed to observe the differences in leach rates of plutonium from identical cement samples [22]. Results shown in Figure 3.10 show significant differences between demineralized water, brine, sodium dominated groundwater, calcium dominated groundwater and bicarbonate dominated groundwater leachants. The leachate 


\section{LEACHANT KEY FOR LEACH TEST CURVES}

\begin{tabular}{|c|c|c|}
\hline CURVE NO & SYMBOL & LEACHANT \\
\hline 1 & 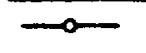 & DEMINERALIZED WATER \\
\hline 2 & $-\infty-$ & WIPP BRINE "B" \\
\hline 3 & $\cdots+\cdots$ & $\begin{array}{l}\text { SODIUM DOMINATED } \\
\text { GROUNDWATER }\end{array}$ \\
\hline 4 & $\cdots \infty$ & $\begin{array}{l}\text { CALCIUM DOMINATED } \\
\text { GROUNDWATER }\end{array}$ \\
\hline 5 & $\rightarrow-\infty$ & $\begin{array}{l}\text { BICARBONATE DOMINATED } \\
\text { GROUNDWATER }\end{array}$ \\
\hline
\end{tabular}

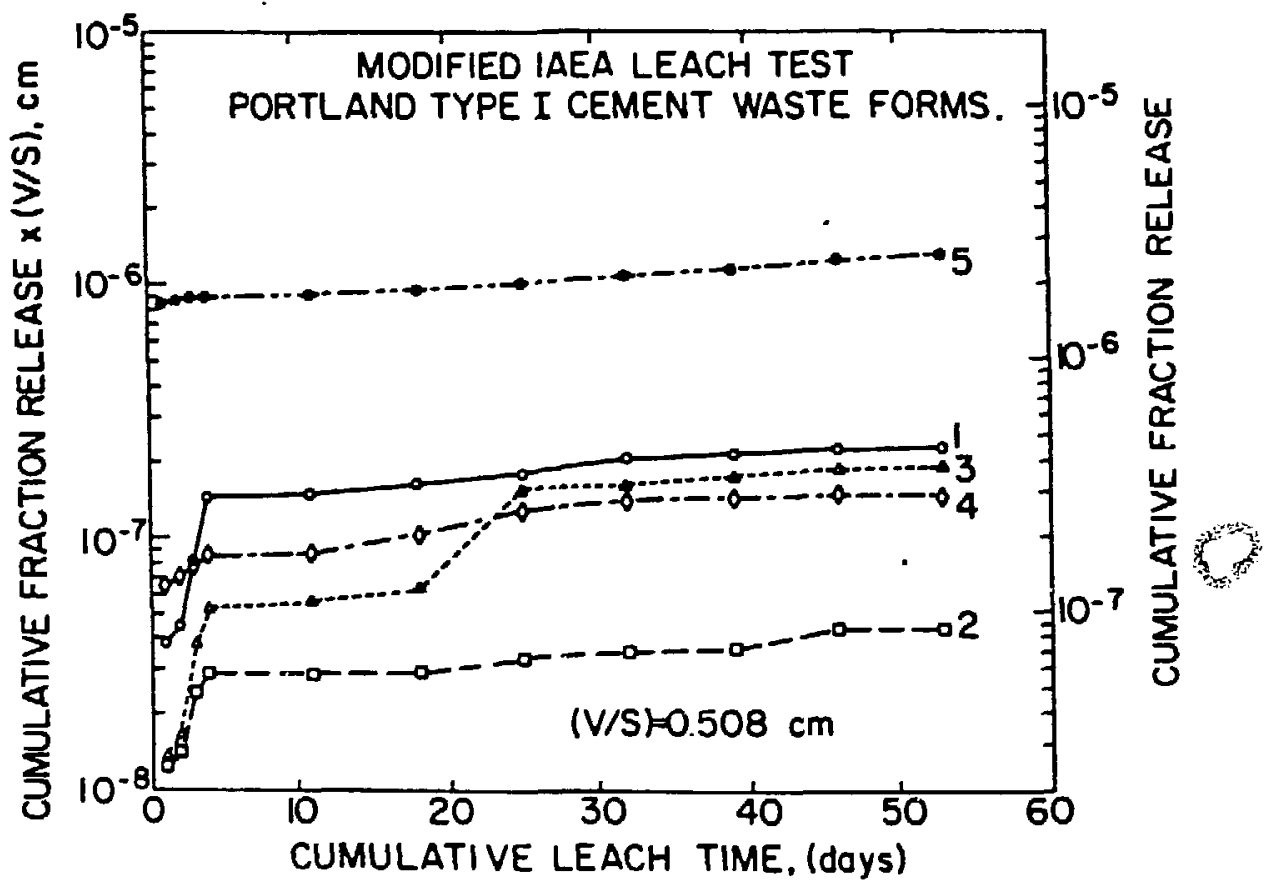

Figure 3.10. Differences in Teachabi1ity from identical cement waste forms in various leachants. 
Table 3.6

Effect of Additives on Cesium Leachability [3.11]

\begin{tabular}{lcr} 
& \multicolumn{2}{c}{$\begin{array}{c}\text { 8 cesium leached } \\
\text { after 28 }\end{array}$} \\
Additive & EAC ${ }^{\mathrm{a}}$ & I-P $^{\mathrm{b}}$ \\
AW-500 & 5.7 & 4.6 \\
Z-900 & 6.0 & 3.9 \\
Vermiculite & 6.3 & 3.8 \\
Z-500 & 6.5 & 4.5 \\
Z-200 & 9.1 & 6.5 \\
Clinoptiloite & 13.1 & 9.2 \\
AW-300 & 17.9 & 9.3
\end{tabular}

a. High Alumina Cement

b. Portland Type I, Pozzalanic Cement

with the greatest fraction release was bicarbonate, that with the least release was brine [22]. In FUEIAP cement leachability for ${ }^{137} \mathrm{Cs}$ in distilled water is $10^{-6} \mathrm{~g} /\left(\mathrm{cm}^{2}\right)$ (day), for ${ }^{90} \mathrm{Sr}$ it is $10^{-4} \mathrm{~g} /\left(\mathrm{cm}^{2}\right)$ (day) and for ${ }^{239} \mathrm{Pu}$ it is $₹ 10^{-8} \mathrm{~g} /\left(\mathrm{cm}^{2}\right)$ (day). Clay additives significantly reduce the ${ }^{137} \mathrm{Cs}$ leaching [23].

\subsubsection{Mechanical Strength}

Mechanical strength is most important during the transportation of the waste form. Good compressive strength and impact resistance are significant properties particularly in the event of transporcation accidents. During storage the principal interest rests in the waste forms ability to support itself without crumbling and thereby increasing its effective surface area and, subsequently, leachability. The strength of cement results from 
cement curing and hydration. This in turn is a factor of age, cure temperature and amount of water in the mix. Amount and type of radioactive waste also significantly affect the strength of concrete. While high compressive strengths are desirable, primary significance should be directed towards avoiding very low compressive strengths.

Compressive strengths for four types of portland cements, pozzolanic cement (I-P) and high-alumina cement (HAC) mixed with each of three sludge types are given in Table 3.7 [3.21] . High-alumina cement achieves the highest compressive strengths as high waste loadings are increased. Compressive strengths for cement waste forms containing evaporator concentrate wastes are also available [3.3].

Compressive strengths for FUEIAP concrete consistently are about 2000 psi for types I and III portland cements [3.18]. Hot pressed cements have been reported to have a maximum tensile strength (5000 psi) with a waste loading of 108. Strength steadily declined with increased percentages of waste. At 508 waste content the tensile strength was $2000 \mathrm{psi}$ [3.17]. The tensile (splitting) strength is about 108 of the compressive strength. Limited impact testing of cement waste forms has been conducted. While compressive strength indicates loading required to fracture the waste form in compression, the most important aspect of waste form performance in impact loading is its tendency to produce particulates. For brittle materials such as cement which have generally high compressive strengths but are weak in tension, impact strength is closely related to the waste forms tensile strength. Figure 3.11 indicates the amount and size of particulates produced in impact loading of cement-diatomaceous earth waste folms as a function of waste loading [3.24]. 


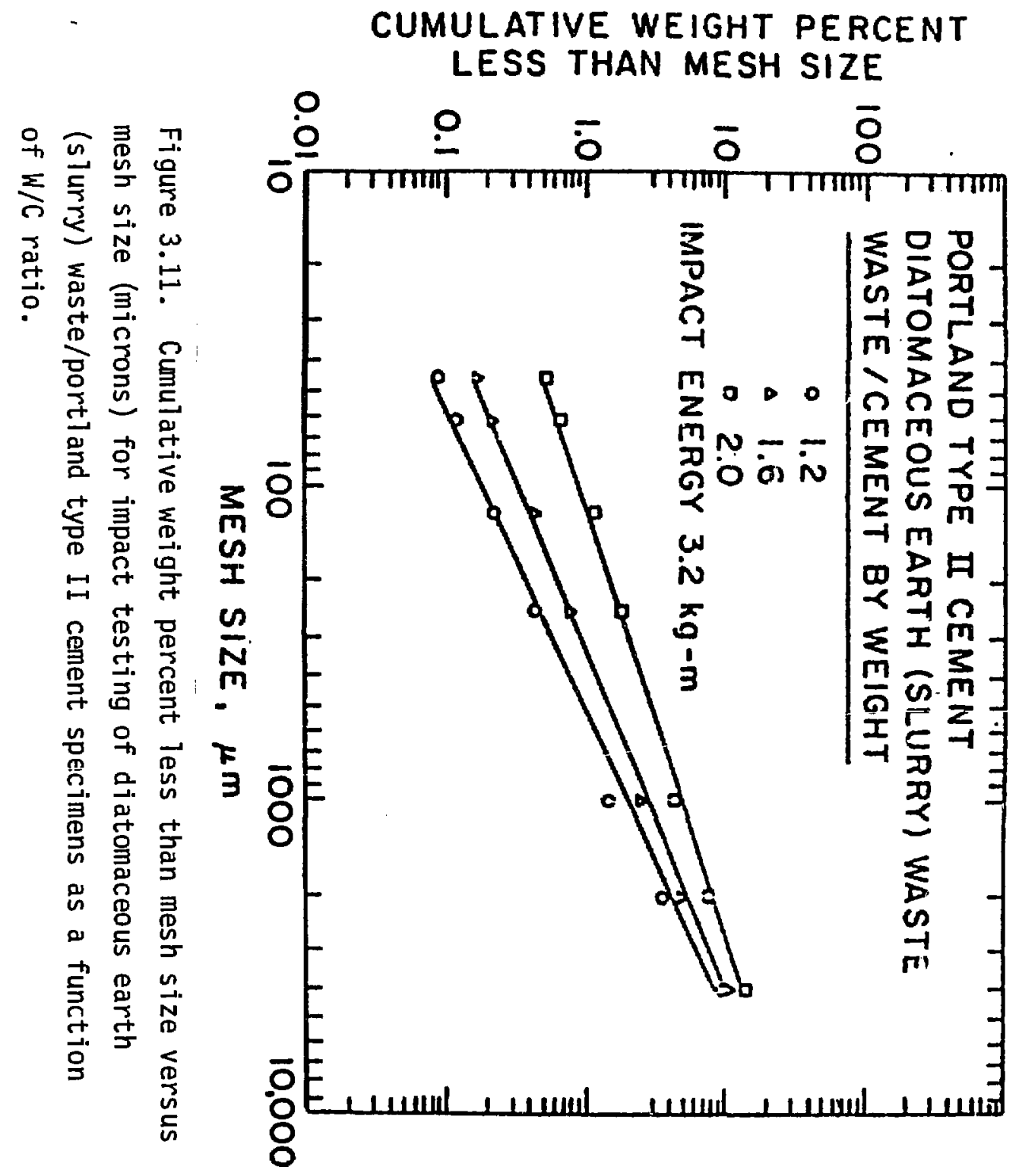


Table 3.7

Compressive Strength of Concrete Waste Forms [3.21]

\begin{tabular}{|c|c|c|c|c|c|c|c|}
\hline \multicolumn{2}{|l|}{ Sluaige } & \multicolumn{6}{|c|}{ Compressive Strength, psi, for Cement Types ${ }^{a}$} \\
\hline Type & Content, 8 & $\bar{I}$ & II & III & $\mathrm{V}$ & $\mathrm{I}-\mathrm{P}$ & $\overline{\mathrm{HAC}}$ \\
\hline None $e^{b}$ & 0 & 10,824 & $11,28.1$ & 13,478 & 11,898 & 11,916 & 9,311 \\
\hline Ib & $\begin{array}{l}10 \\
25 \\
40\end{array}$ & $\begin{array}{r}8,402 \\
4,588 \\
464\end{array}$ & $\begin{array}{l}8,243 \\
4,630 \\
1,259\end{array}$ & $\begin{array}{l}8,694 \\
6,180 \\
1,456\end{array}$ & $\begin{array}{l}8,829 \\
5,620 \\
3,054\end{array}$ & $\begin{array}{l}8,296 \\
4,472 \\
2,380\end{array}$ & $\begin{array}{l}9,574 \\
5,792 \\
4,354\end{array}$ \\
\hline IIb & $\begin{array}{l}10 \\
25 \\
40\end{array}$ & $\begin{array}{l}8,973 \\
5,779 \\
3,932\end{array}$ & $\begin{array}{l}9,045 \\
6,412 \\
3,352\end{array}$ & $\begin{array}{l}9,321 \\
7,230 \\
4,736\end{array}$ & $\begin{array}{r}11,159 \\
7,158 \\
4,234\end{array}$ & $\begin{array}{l}7,692 \\
5,855 \\
3,311\end{array}$ & $\begin{array}{l}9,624 \\
7,158 \\
5,884\end{array}$ \\
\hline IIIb & $\begin{array}{l}10 \\
25 \\
40\end{array}$ & $\begin{array}{l}9,313 \\
5,171 \\
2,388\end{array}$ & $\begin{array}{l}7,557 \\
4,627 \\
2,884\end{array}$ & $\begin{array}{l}7,603 \\
5,817 \\
3,317\end{array}$ & $\begin{array}{l}8,490 \\
4,732 \\
2,700\end{array}$ & $\begin{array}{l}7,761 \\
4,930 \\
3,088\end{array}$ & $\begin{array}{l}8,465 \\
6,658 \\
3,371\end{array}$ \\
\hline
\end{tabular}

a. Each entry is the average of six measurements.

b. Error factor E (95\% confidence), where upper limit is $x$ E. and lower limit is /E: No sludge, $E=1.15$; sludge I, $E=1.12$; Sludge II, $E=1.15$; Sludge III, $E=1.08$.

\subsubsection{Radiation Stability}

Stability of the waste form to radiation interactions is desirable to prevent the degradation of wasta form properties and container pressurization resulting from gaseous radiolysis products. Waste form leachability, mechanical strength, dispersibility, and physical form may be affected by radiation. Gaseous radiolysis products may result in waste container pressurization land possible failure), and the gaseous species produced may also be poitentially explosive or radioactive themselves. Since it would typically take a long time to accumulate a substantial radiation dose from low-level waste forms because of their activity content, the immobility of their radioactive contents becomes of concern primarily in disposal. For example, cumulative radiation doses as a function of time are shown in Figures 3.12 and 3.13 as a 


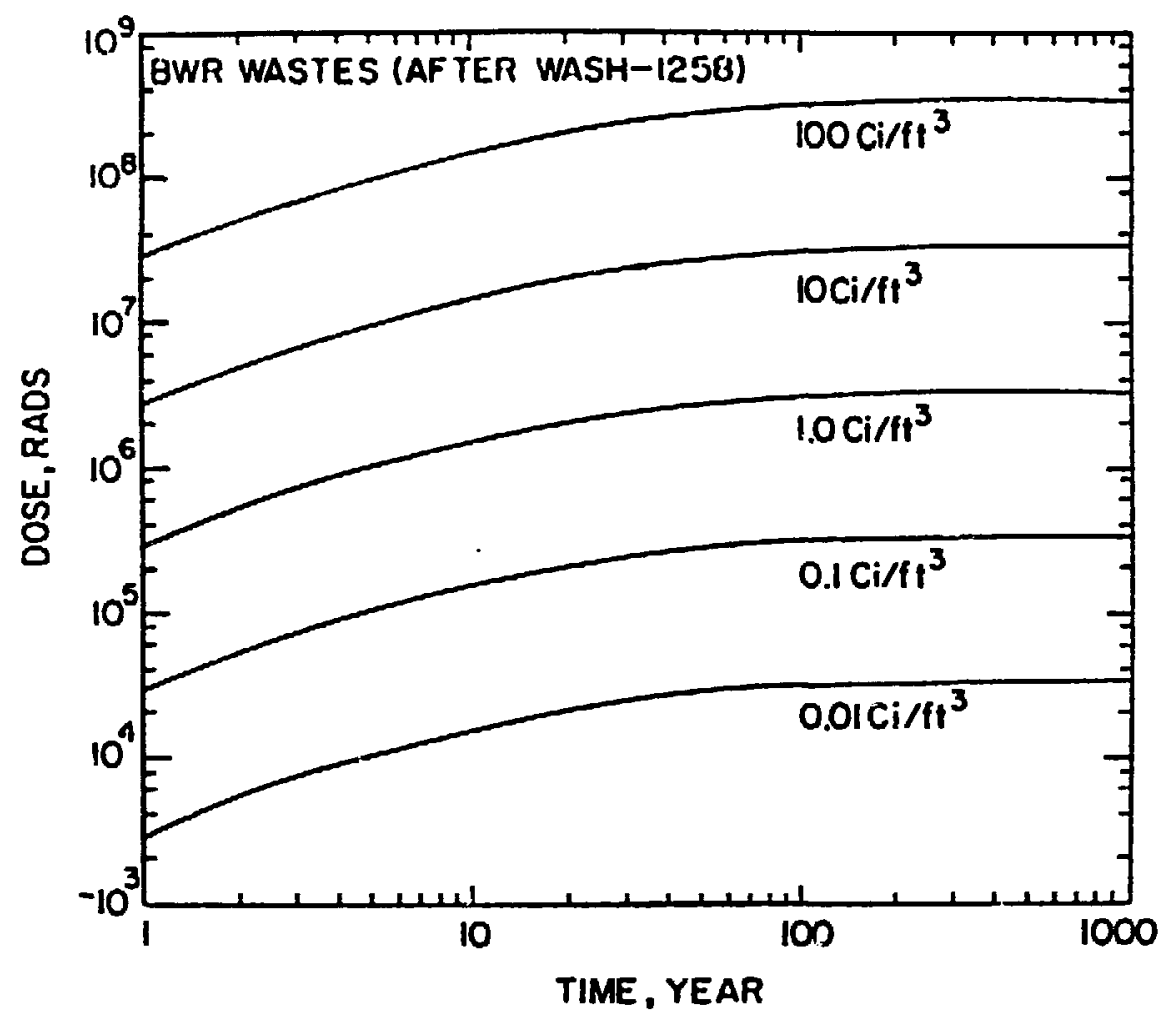

Figure 3.12. Cumulative radiation dose for BWR waste forms as a function of activity concentrations.

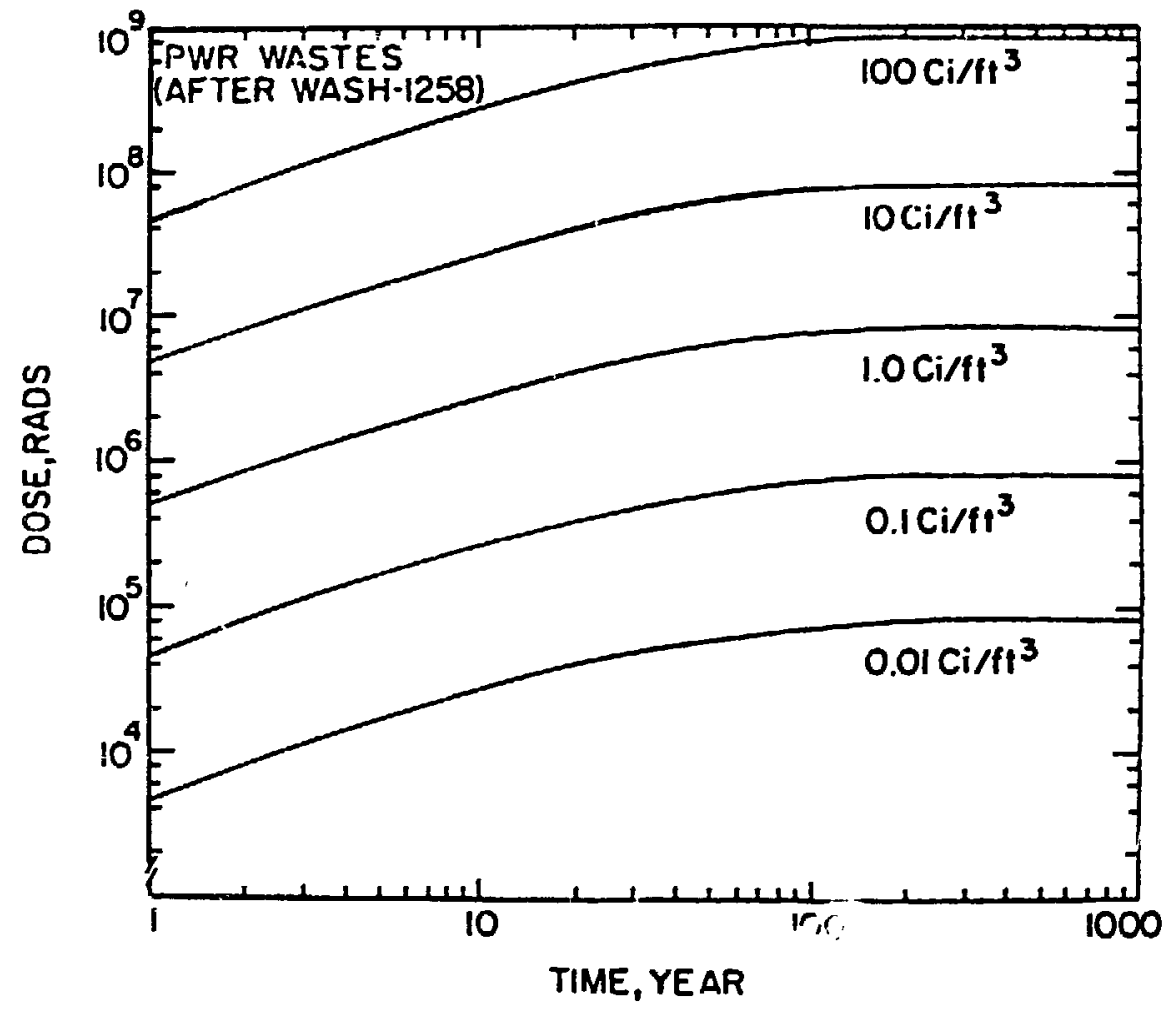

Figure 3.13. Cumulative radiation dose for PWR waste forms as a function of activity concentrations. 
function of activity concentration for boiling water reactor (BNR) and pressurized water reactor (PWR) wastes respectively. Observed activity levels in light water reactor (IWR) solidified radwaste are listed in Table 3.8. The differences in shielding properties of the various solidification agents at typical waste/binder ratios must also be considered in relation to waste package handling and personnel exposure.

Table 3.8

Observed Activity Levels for INR Solidified Radwaste [3.26]

\begin{tabular}{|c|c|c|c|c|}
\hline & & $\begin{array}{l}\text { Evaporator } \\
\text { bottoms }\end{array}$ & $\begin{array}{c}\text { Filter/ } \\
\text { demineralized } \\
\text { resins }\end{array}$ & $\begin{array}{c}\text { Filter/ } \\
\text { demineralizer } \\
\text { sludge }\end{array}$ \\
\hline \multirow[t]{2}{*}{ BWR } & $\begin{array}{l}\text { Generation rate (ft3 /MNE) } \\
\text { Activity content (Ci/ft3) }\end{array}$ & 25.5 & 4.0 & 19.5 \\
\hline & $\begin{array}{l}\text { Range } \\
\text { Average } \\
\text { Av. total activity (Ci/MWE) }\end{array}$ & $\begin{array}{c}0.0003-0.14 \\
0.39 \\
1.0 \\
30.7\end{array}$ & $\begin{array}{c}0.001-6.5 \\
2.0 \\
8.0 \\
2.7\end{array}$ & $\begin{array}{c}0.004-20.0 \\
2.0 \\
3.9 \\
-\end{array}$ \\
\hline \multirow{2}{*}{ FWR } & $\begin{array}{l}\text { Generation rate ( } \mathrm{ft} 3 / \mathrm{MNE}) \\
\text { Activity content }(\mathrm{C} / \mathrm{ft} 3)\end{array}$ & & & - \\
\hline & $\begin{array}{l}\text { Range } \\
\text { Activity } \\
\text { Av. total activity (Ci/MNE) }\end{array}$ & $\begin{array}{c}0.002-0.4 \\
0.045 \\
1.4\end{array}$ & $\begin{array}{c}0.03-37.0 \\
4.5 \\
12\end{array}$ & $\bar{z}$ \\
\hline
\end{tabular}

Hydrogen is the predominant species produced by garma radiolysis of concrete waste forms and results from the decomposition of water. Work using ${ }^{60} \mathrm{Co}$ gamma irradiation indicates that the initial rate of $\mathrm{H}_{2}$ production is proportional to dose rate $[3.25]$. As the radiation dose increases, $\mathrm{B}_{2}$ pressurization increased (and the rate of $\mathrm{H}_{2}$ prixuction decreased) until a steady state container pressurization was attained as shown in Figure 3.14. The steady state $\mathrm{H}_{2}$ pressure decreased as the dose rate decreased, as shown in Figure 3.15. The $G$ value for $\mathrm{B}_{2}$ production, $\left(\mathrm{G}\left(\mathrm{H}_{2}\right)\right.$, molecules/100eV absorbed 


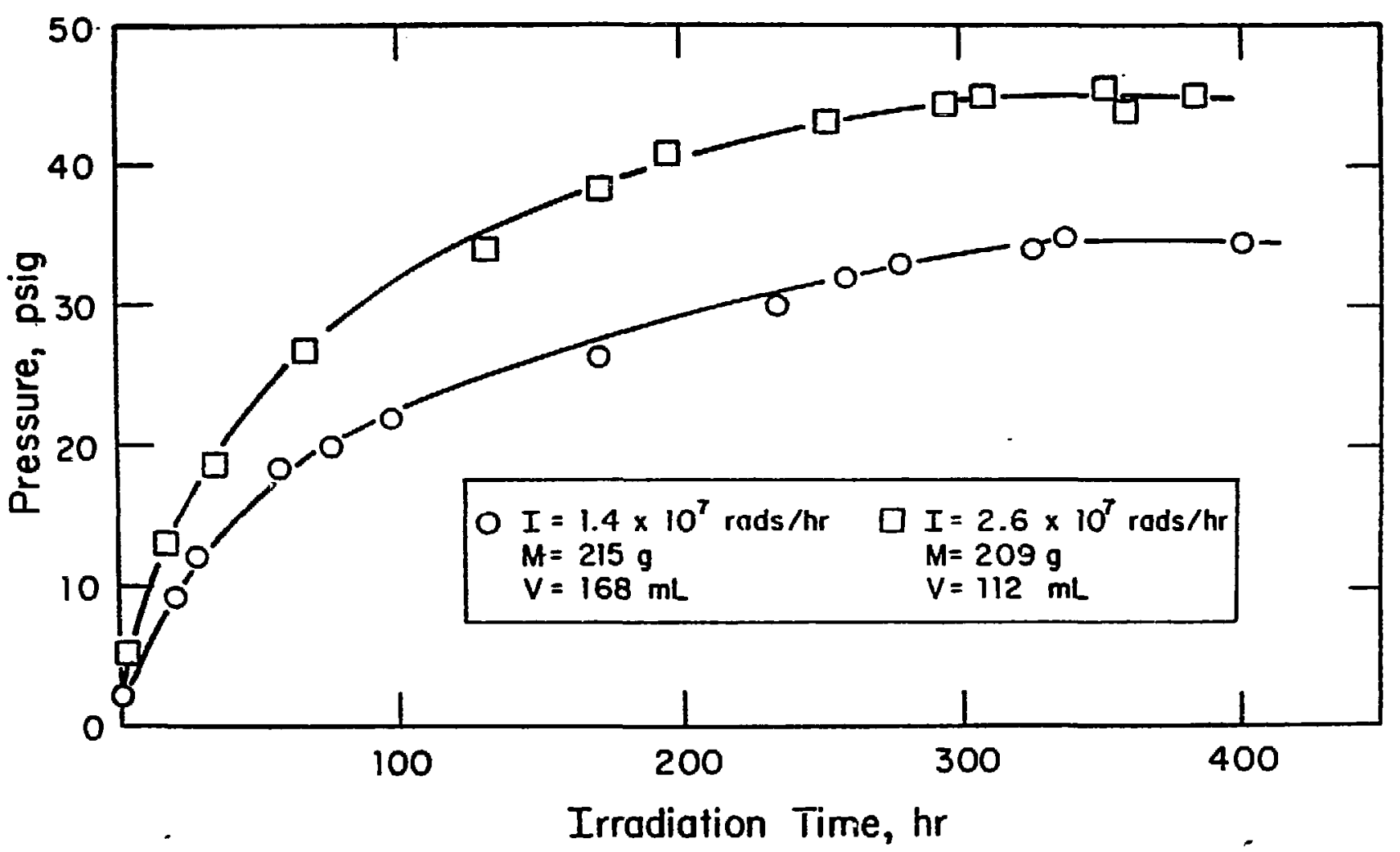

Figure 3.14. Pressurization from gamma radiolysis of concrete at $47^{\circ} \mathrm{C}$.

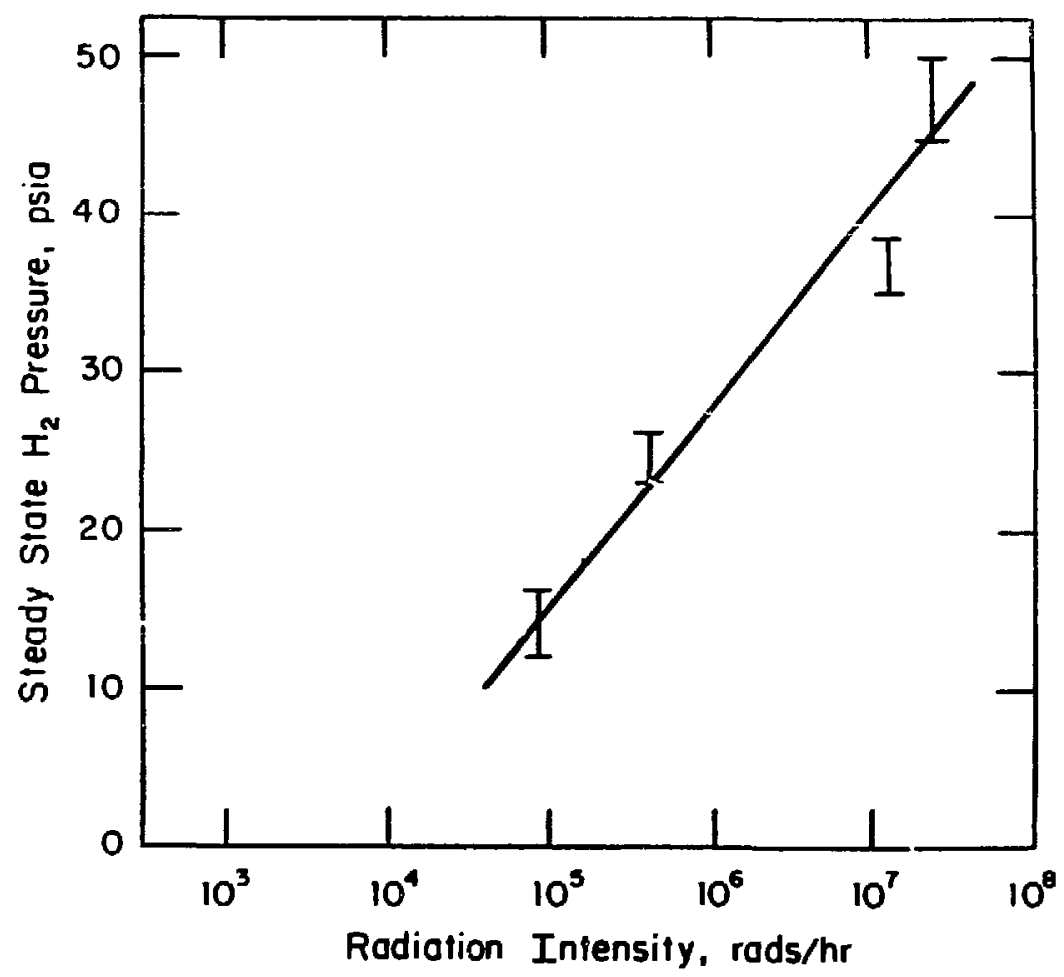

Figure 3.15. Effect of dose rate on steady state $\mathrm{H}_{2}$ pressure from gamma radiolysis of concrete. 
energy) was 0.03 molecules/100 eV and was independent of dose rate over the range studied. In these tests, oxygen in the air sealed in the container was partially consumed and nitrogen was unaffected. The steady state container pressurization extrapolated to the dose rate of typical low-level waste products is 10w (below 10 psi). This steady state pressurization may not in fact be realized since at low dose rates, the rate of hydrogen diffusion out of the container may be comparable to or greater than the rate of hydrogen production.

Gas generation may be reduced by the addition of nitrate and nitrite ions and by the reduction of free water content within the cement [3.22]. The latter may be accomplished by heating the cement waste form above $100^{\circ} \mathrm{C}$ or by employing one of the pressing techniques described earlier. An additional feature of the FUEIAP product appears to be the catalytic recombination of radiolytic hydrogen and oxygen, thus reducing the gas froblem [3,22].

\subsubsection{Thermal Properties}

The thermal stability of a waste form may influence its ability to retain activity in certain erviroments. It is of concern during transportation and to a lesser extent during interim storage. The greatest potential for radionuclide release would result from accident conditions with external fires. Waste form temperature increases may cause melting, decomposition, combustion, degradation of mechanical properties, and dispersion of radionuclides in the form of gas, smoke, or aerosol. The waste form container, which serves as a barrier to release, may be breached by the accident conditions or by pressurization due to waste decomposition. Other less severe envirorments may also produce some thermal degradation of the waste form. Thermal stability is determined by symergistic interactions of the solidification agent and the incorporated waste. 
Upon heating at $100^{\circ} \mathrm{C}$, portland cement waste forms will slowly lose weight due to evaporation of uncombined but physically held (in the pore structure) water. Additional water can be removed at higher temperatures due to dehydration of the lower stability hydrated compounds. While this results in a decrease in mechanical strength properties the waste form will normally retain its integrity. Heating to $100^{\circ} \mathrm{C}$ for up to three months was shown to result in a 6-168 decrease in weight due to the loss of capillary water; this caused a 258 loss in compressive strength [3.21]. Heating at high temperatures (above $400^{\circ} \mathrm{C}$ ) for long times leads to severe degradation of the cement waste form (although same cements, notably high alumina cement, are refractory cements and will retain their integrity).

Exposure to the themal enviroment resultant from a petroleum fire after a transportation accident, will typically produce minimal effects with full-size cement waste forms (55 gallon drum size or larger). This is a consequence of the low thermal conductivity of cement waste forms, which has been measured as $0.0029 \mathrm{cal} / \mathrm{cm}-\mathrm{sec}$-degree $\mathrm{C}$ [3.4]. In effect, while the exterior of the waste form is heated to high temperatures, the interior of the waste form is not subjected to significant heat unless the time in the high temperature environment is very long. Flammability tests (ASIM D635-74) characterize portland cement waste forms as non-flammable [3.4].

\subsection{Advantages and Disadvantages}

Table 3.9 presents advantages and disadvantages of employing cement as a solidification matrix for low-level radioactive waste. Perhaps the greatest advantage to its use is that cement is a well known, cormon material which is particularly adaptable to a variety of conditions. Note that in this (and subsequent) comparison tables particular items are often of much greater importance than others. Hence, the number of advantages and/or disadvantages for a particular matrix is not in itself significant. 
TABLE 3.9

Advantages and Disadvantages of Cement Solidification

1. Material and technology we11 known and available

2. Compatible with many wastes

3. Most aqueous wastes chemicaliy bound to matrix

4. Low cost of cement

5. Good self-shielding

6. No vapor problems

7. Long shelf life of cement powder

8. Good impact and compressive strengths

9. Low leachability for some radionuciides

10. No free water if properly formulated

11. Rapid, controllable setting-no differential setting

12. In container and in-line mixing processes available
1. Some wastes affect setting or otherwise produce poor waste forms

2. $\mathrm{pH}$ sensitive-pretreatment of waste may be necessary

3. Swelling and cracking occurs with some products under exposure to water

4. Volume increase and high density in shipping and disposal

5. Excessive setting exotherms may develop with certain cement and waste combinations

6. Dust problems with some systems

7. Equipment for powder feeding difficult to maintain

8. Potential maintenance problems resulting from premature cement setting, especially in-line mixers

9. Requires heating and/or pressing equipment for some processes (hot pressed and FUETAP materials) 
[3.1] Double, D.D. and Hellawell, A., "The Solidification of Cement," Scientifis American. pp. 82-90, 1977.

[3.2] Erownstein, M. and Levesque, R.G., Experience with Cement Usage as the Binding Agent for Radwaste, ASME Publication \#78-NE-15.

[3.3] Colmbo, P. and Neilson, R.M., Jr., Properties of Radioactive Wastes and Wasiz Containers - First Topical Report, BNL-NUREG-50957, Brookhaven National Laboratory, Upton, New York, 1979.

[3.4] Lokken, R.O., A Review of Radioactive Waste Immobilization in Concrete, FiL-2654, Battelle Pacific Northwest Laboratories, Richland, WA, 1978.

[3.5] Blanks, R.F. and Kennedy, H.L., "The Technology of Cement and Concrete," Concrete Materials, Volume 1, John Wiley \& Sons, Inc., p. 28, New York, 1955.

[3.6] Manowitz, B., et. al., SRL, Iong-Term Waste Storage Support Program, Progress Report, Brookhaven National Laboratory, Upton, N.Y., 1973.

[3.7] Lea, F.M., The Chemistry of Cement and Concrete, 3rd Edition, Edward Arnold (publishers) Ltd., Glasgow, 1970.

[3.8] Moore, J.G., Development of Cementitious Grouts for the Incorporation of Radioactive Waste, Part 2: Continuation of Cesium and Strontium Ieach Studies, Oak Ridge National Laboratory, Oak Ridge, TN., ORNL-5142, 1976.

[3.9] Rudolph, G. and Koster, R., "Immobilization of Strontium and cesium in Intermediate-Level Liquid Wastes by Solidification in Cements", Scientific Basis for Nuclear Waste Management, Vol. I, G.J. MoCarthy ed. Plenum Press, New York, N.Y., pp. 467-470, 1978.

[3.10] Granlund, R.W., A Comearison of Bentonite Clays with Conasauga Shale for the suporession of cesium leaching from Liquid waste solidified by the Chemfix Process, Delaware Custom Material, Inc., State College, PA, Oct. 1977.

[3.11] Plodinec, M.J., Evaluation of ${ }^{137} \mathrm{Cs}$ sorbents For Fixation in Concrete, DP-1444, Savannah River Laboratory, Aiken, SC, 1977.

[3.12] Roy, D.K., Daimon, M., Scheetz, B.E., Wolfe-Confer, D., And Asoga, K., "Role of Adnixtures in Preparing Dense Cements for Radioactive Waste Isolation," Scientific Basis for Nuclear Waste Management, Vol. I, G.J. McCarthy ed., Plenum Press, NY, pp. 461-466, 1975.

[3.13] Colambo, P. and Neilson, R.M., Jr., "Some Techniques for the Solidification of Radioactive Wastes in Concrete," Muclear Technology, 32 (1), pp. 30-38, 1977. 
[3.14] Moore, J.G., Devoney, H.E., Godbee, H.W., Morgan, M.T., Rogers, G.C., Williams, C, and Newman, E., The Fixation of Radigactive Wastes in Con= cretes and Cementitious Grouts, Tech. Meeting \#B, 4/7, Oak Ridge National Laboratory, Oak Ridge, IN.

[3.15] Weeren, H.O., "Enviromental Effects of Disposal of Intermediate-Level Wastes by Shale Fracturing," CONF 78110-6, 71 Annual Meeting of American Institute of Chemical Engineers, Miami, Fla., 1978.

[3.16] Christensen, H., "Solidification of Nuclear Wastes in Concrete," Alternative Nuclear Waste Forms and Interactions in Geologic Media - A Workshop, Gatlinburg, Tenn., May 1980.

[3.17] Roy, D.M. and Gouda, G.R., "High Level Radioactive Waste Incorporation into (Special) Cements," Nuclear Technology, 40 (9), 1978.

[3.18] Moore, J.G., Newman, E., Rogers, G.C., Radioactive Waste Fixation in EUFHAP (Fonmed Under Flevated Temperature and Pressure) Concretes - Fxperimental Program and Initial Results, ORNL/TM-6573, Oak Ridge National Laboratory, Oak Ridge, TN, 1979.

[3.19] Bida, G., Davis, R.E. and Mackenzie, D.R., NRC Nuclear Waste Management Technical support in the Develogment of Nuclear Waste Form Criteria: Task 2: Alternative TRU Technologies, BNL-NUREG-27715, Brookhaven National Laboratory, 1980.

[3.20] Lerch, R.E., Greenhalgh, W.O., Portridge, J.A. and Richardson, G.L., Treatment and Immobilization of Intermediate Ievel Radioactive Wastes, HEDI-SA-1244, Hanford Engineering Development Laboratory, Richland, WA, 1977.

[3.21] Stone, J.A., Evaluation of Concrete as a Matrix for solidification of Savannah River Plant Waste, DP-1448, Savannah River Laboratory, Aiken, SC, June, 1977.

[3.22] Neilson, R.M., Colambo, P. and Bradley, D., "Plutonium Leachability From Alternative Transuranic Incinerator Ash Waste Forms," IAFA-SM-2465, International Symposium on the Management of Alpha-Contaminated Wastes, International Atomic Agency, Vienna, Austria, 1980.

[3.23] Stone, J.A. Goforth, S.T. and Smith, P.K., Preliminary Evaluation of Alternative Forms for Immobilization of Savannah River Plant High-Ievel Haste, DP-1545, Savannah River Laboratory, Aiken, SC, 1979.

[3.24] Neilson, R.M., Jr., and Colombo, P., Properties of Radioactive Wastes and Containers, Progress Report No. 11, BN-NUREG-51042, Brookhaven National Laboratory, Upton, NY, 1979.

[3.25] Bibler, N.E. and Orebaugh, E.G., Radiolytic Gas Production Erom Tritiated Waste Forms, DP-1459, Savannah River Laboratory, Aiken, SC, 1977.

[3.26] A survey and Evaluation of Handling and Disposing of solid Lom-Tevel Muclear Fuel Grcle Wastes, National Environmental Studies Project, AIF/NESP-008, Atomic Industrial Forum, Inc., 1976. 


\section{BIIUMEN AS AN AGENT FOR LOW-LEVEL WASTE SOLIDIFICATION}

Bitumen has been used to solidify radioactive waste since a pilot plant at Mol, Belgium was cormissioned in 1962. Much of the research in the methodology of bitumen solidification and the subsequent application to actual operations has occurred in Europe. A notable exception is the work at ORNL with emulsified asphalt. Among the plants utilizing bitumen as a solicifcation medium for low-level and intermediate-level waste are those operating at Mol, Belgium; Marcoule, France; Harwell, England and Rarlsruhe, Federal Republic of Germany •

\subsection{Description of Bitumen}

Bitumen or asphalt is a mixture of high molecular weight hydrocarbons which is obtained as a residue in petroleum or coal tar refining. It has two major components: asphaltene compounds, which give bitumen colloidal properties, and malthene compounds, which impart viscous liquid properties. Bitumen is a thermoplastic material and can behave mechanically as either a viscous liquid or a solid depending on temperature [4.1]

The incorporation of waste in bitumen usually relies upon its thermoplastic properties. The bitumen is typically heated in the presence of waste, with the heat serving both to liquify the bitunen sufficiently for mixing and to evaporate water from the waste, thereby providing volume reduction of the waste. Waste solids are thus mixed and coated with bitumen in a liquid state. Upon cooling, waste solids are mechanically held in a solid bitumen matrix. Exceptions to ermploying the thermoplastic properties of bitumen are emulsified 
bitumen processess where a solvent is used to liquify bitumen at room temperatures. The water in the waste is removed thermo-mechanically while mixing the waste with the bitumenous material. The mixture solidifies as the solvent is allowed to evaporate.

\subsection{Bitumen}

There are five generic types of bitumen available with differing properties which make them appropriate for a variety of uses. Bitumen, being a natural material, can vary significantly from batch to batch. Therefore, specific conmercial products have been developed which are made to conform to a relatively narrow range of properties. Even these materials will vary somewhat in characteristics in different shipments of the same named product and grade. The five major types of bitumen are listed below [4.2]:

(1) Straight-run distillation bitumen (the residue afte: distillation of heavy petroleums)

$\begin{array}{ll}\text { Softening point } & \text { from } 34 \text { to } 65^{\circ} \mathrm{C} \\ \text { Penetration } & \text { frcm } 22 \text { to } 2 \mathrm{~mm}\end{array}$

(2) Oxidized bitumens (Highly collodial bitumen products formed by blowing air heated to $300^{\circ} \mathrm{C}$ through certain petroleums). Temperature fluctuations usually have little effect on oxidized bitumens.

$$
\begin{array}{ll}
\text { Softening point } & 70-140^{\circ} \mathrm{C} \\
\text { Penetration at } 25^{\circ} \mathrm{C} \text { ranges } & 0.7 \text { to } 4.5 \mathrm{~mm}
\end{array}
$$

(3) Cracked bitumens (obtained by pyrogenic breakdown of heavy molecules). Temperature fluctuations have a considerable effect on cracked bitumens. They are used mainly in cases where good flow at high temperatures and subsequent rapid hardening on cooling is required.

Softening point

Penetration at $25^{\circ}$

$$
\begin{aligned}
& 77-85^{\circ} \mathrm{C} \\
& <0.5 \mathrm{~mm}
\end{aligned}
$$


(4) Bitumen emulsions (formed by the emulsification of bitumen in soapy water). There are two types of bitumen emulsions: anionic (emulsifier: alkaline soap) and cationic (emulsifier: amine salt). Bitumen emulsions can be used without previous heating. On contact with a prepared surface, the emulsion spreads over it, the water evaporates and a rigid coating is left.

(5) Pitches (bitumens liquified by addition of a solvent)

The two types most widely used for the solidification of radioactive wastes are straight run distillation bitumens and the oxidized bitumens. The Werner and Pfleiderer Corporation reconmends the use of Pioneer 221 bitumen (Witco Chemical Corporation) in their domestic solidification system installations [4.1]. This material is a steep roofing type of asphalt which has the characteristics given in Table 4.1. Other named products that have been employed extensively in European applications include Mexphalt 10/20 and Shell pH 55-65.

\subsection{Additives}

A variety of additives have been used with bitumen to either increase the ability of the waste form to retain radionuclides or to improve the physical characteristics of the form itself.

The addition of clay minerals, other natural earth materials and synthetic products has been used to reduce the leachability of specifications such as ${ }^{90} \mathrm{Sr}$ and ${ }^{137} \mathrm{Cs}$. Similar materials have been incorporated in cement waste forms for the same purpose. Same of the products used are: Bentonel AF (calcic magnesium bentonite), Betsil RV (marine diatoms), calcium silicate, Argisil A (sepiolite), and activated alumina [4.3]. Addition of 2 wto water glass $\left(\mathrm{Na}_{2} \mathrm{SiO}_{3}\right)$ resulted in 50-90\% decreases in the observed leach rate for ${ }^{137} \mathrm{Cs}$ from similar waste forms without the additives [4.3]. These sane additives were also found to significantly reduce the flamability of samples containing 60 wto nitrate salts [4.3]. 
Characteristics of a Typical Bitumen Used for Radioactive Waste Solidification [4.1]

Property

Softening point

Flash point of Volatiles (ASIM Test D-92)

Percent Volatiles by Volume

Ignition Point (Minimum)

Specific Gravity ( $g / c c)$

Viscosity $\left(250-400^{\circ} \mathrm{F}\right)$

Penetration

Vapor Pressure

Vapor Density (Air=1)
Specification

$200^{\circ} \mathrm{F}$ or $93^{\circ} \mathrm{C}$

$500^{\circ} \mathrm{F}$ or $288^{\circ} \mathrm{C}$ minimum

0.18

$600^{\circ} \mathrm{F}$ or $315^{\circ} \mathrm{C}$

1.05

900-100 cP

2.2-3 mm $77^{\circ} \mathrm{F}$ or $25^{\circ} \mathrm{C}$

4.0-6 $\mathrm{mm} 115^{\circ} \mathrm{F}$ or $46^{\circ} \mathrm{C}$

$1.3-1.8 \mathrm{~mm} 32^{\circ} \mathrm{F}$ or $0^{\circ} \mathrm{C}$

$1 \mathrm{mIm}$ Hg maximum

0.01 maximum

Other materials, often clay products, are used to control the properties of the solidified waste form. Organic liquids can dissolve bitumen so that a solid waste form cannot be produced. Experiments at ORNL have used a variety of materials to act as fillers, allowing the bitumen mixture to flow at about $160^{\circ}$ but solidify adequately at $25^{\circ} \mathrm{C}$. The organic liquid used was tributyl phosphate (IBP) and the fillers used were: Attapulgite-150 (a drilling clay), Attaclay Filler, Neospectra Mark I Filler (carbon black) and Cab-0Sil Filler (high surface area silica). Attapulgite-150 was the only material which provided an acceptable waste form; this in the proportions of 25 wto TBP, 38 wto bitumen and 37 wto Attapulgite-150. Irradiation to $10^{8}$ rads with ${ }^{60} \mathrm{C} 0$ caused no change in the waste form $[4.2,4.4]$. 


\subsection{Waste Fom Preparation}

There are five basic methods used to produce mixtures of bitumen and weste. In these methods, heat is required to soften the bitumen and/or is used to evaporate water. In all cases, the off-gases generated are treated for volatilized organic oils which are driven from the bitumen during heating,

\subsubsection{Stirred Bitumen Process (Mol_Method)}

The first process for encapsulation of radioactive waste in bitumen was developed at Mol, Belgium. In this process, liquid or solid wastes are mixed with molten bitumen at a temperature of $160^{\circ}$ to $230^{\circ} \mathrm{C}$ with simultaneous evaporation of water and volatile constituents [4.2]. Figure 4.1 shows a schematic of the improved version of the "Mummy" installation at Mol. A similar plant was put into use at AERE, Harewell, UK in 1968 [4.5].

The method of fixing wastes in bitumen developed in Mol, Belgium, uses non-emulsified asphalts. Radioactive concentrates (sludges) obtained after filtration on a drum filter are fed by a screw conveyor into a mixer-evaporator. The evaporation of the remaining moisture and mixing of the solid waste residue with molten bitumen takes place at a temperature between 200 to $230^{\circ} \mathrm{C}$ and is accompanied by vigorous stirring. The maximum content of solid wastes incorporated in the final product does not exceed 458 , thus ensuring a uniform waste form on cooling [4.2]

The basic apparatus, a mixer-evaporator, is a cylindrical steel tank with a flat bottom divided internally into two sections, a lower one called the "mixing chamber" and an upper one called the "expa ; on chamber". The process of mixing sludge with molten bitunen takes place in the mixing chamber, while the expansion chamber serves for quenching of the foam which may be formed when sludges with a high water content are processed. At the 


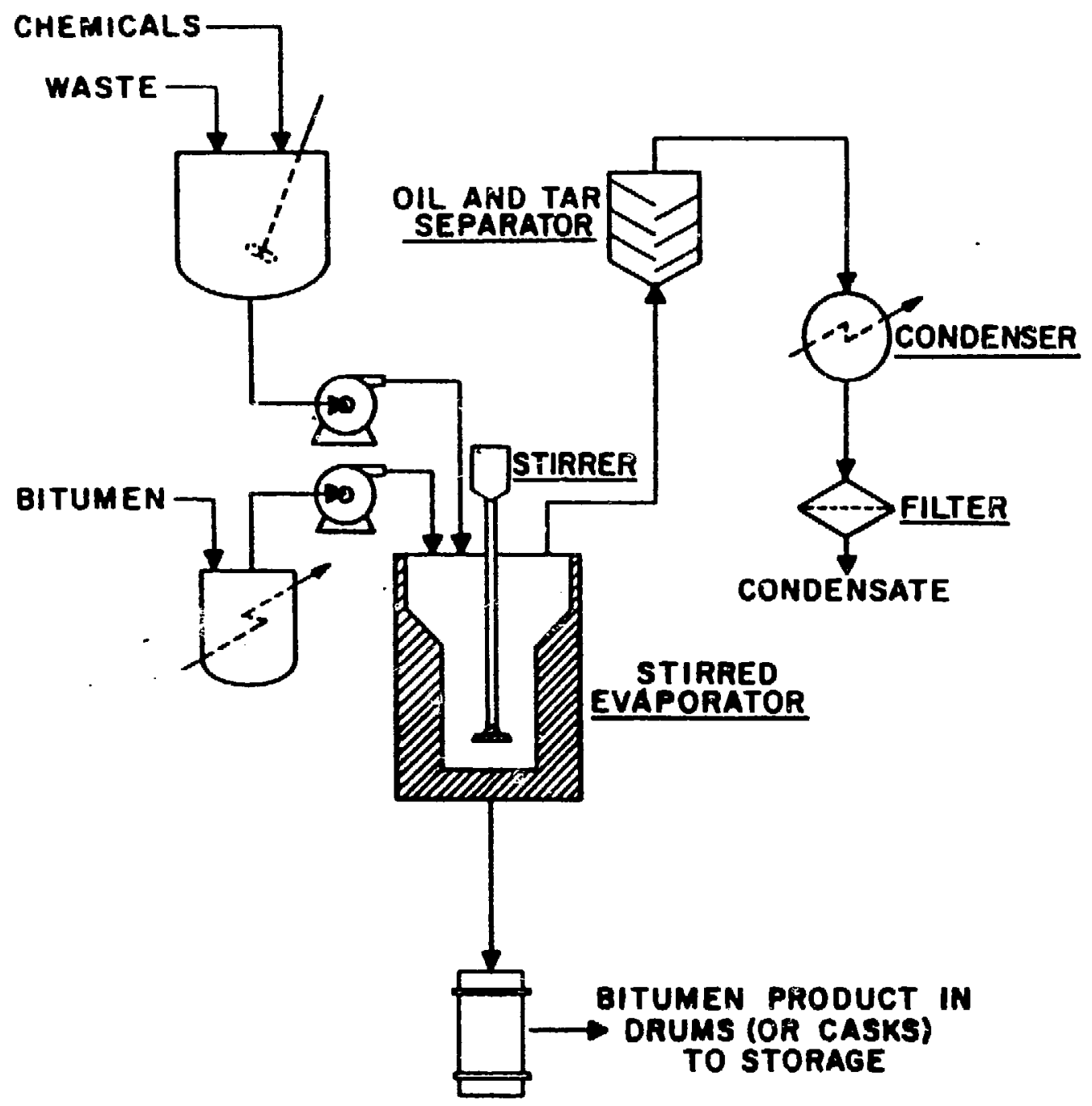

Figure 4.1. Schematic of tia stirred bitumen process. 
bottom of the mixer-evaporator there is an outlet valve equipped with a heating mantle. System throughput is determined by the water content of the waste. The Mol system can evaporate up to 100 liters of water per hour. When the waste solids content in the bitumen reaches about $40 \%$, the mixture is discharged into 55 gallon dr'ms. This is accomplished by pressing the barrels against the discharge outlet valves by means of a hydraulic lift so that a hermetic seal is produced. The mixture is allowed to cool and solidify, after which the drums are sealed with steel lids. Some drums can $L=$ neated keeping the bitumen fluid in order to allow incorporation of plastic wastes into the form [4.2]. Process off-gases are treated for volatilized bituminous oils.

At the Harwell installation a different type of sludge treatment was adopted for which vibratory feed equipment was unsatisfactory. The solution was to treat the sludge in a slowly rotating drum. At 50-60 wto solid content, the sludge takes the form of spherical pellets. When dropped into hot bitumen the water remaining in these pellets is rapidly heated, causing the pelicts to disintegrate, spreading the dehydrated waste throughout the bitumen. Drying in this way drastically reduces the mixing time necessary [4.5] . Fire suppression systems are normally incorporated in these installations since bitumen is flammable. In one instance, a fire was accidentally started at the Earwell plant when the mixing device stopped while the immersion heating elements were still energized. This resulted in extreme local heating and ignition of the asphalt near the heaters. The fire was extinguished by the $\infty_{2}$ sprays which are built into the system [4.5].

\subsubsection{The "Temporary Emulsion" Process}

The "Temporary Emulsion" process developed at Marcoule, France entails the mixing of sludges, emulsifying agents and bitumen together, separation of the water from the emulsion resulting in bitumen coated sludge 
particles, and finally complete drying of the product [4.2]. Figure 4.2 is a schematic of this process [4.2].

The sludges are nomally concentrated by using a rotary filter to remove water, and are then fed to the "coating" machine together with the bitumen and the surface-active agents. In the first coatings section of the process, mixing and coating of the solid particles takes place together with separation of approximately $80 z$ of the water while the temperature is maintained at about $90^{\circ} \mathrm{C}$. In the second coating section, the temperature is raised to $110^{\circ} \mathrm{C}$ facilitating further mixing of waste with the bitumen and separation of remaining water. Transport, mixing and water separation in the coating machine are achieved through the movement of the mixture, via screws of various pitches and velocities, thereby pressurizing and depressurizing the bitur men-waste mixture as it is processed. Final dehydration (to $<0.58$ water) of the product is achieved in a twin screw drying machine at temperatures of $130^{\circ} \mathrm{C}$, fram which the bituminous waste is discharged into drums. The plant described is capable of handling $600 \mathrm{~kg}$ of sludge per hour and started operation in 1966 following intensive trials [4.2].

\subsubsection{Sedimentation Process}

Another type of process, developed in Austria, employs the greater density of dried salts campared to that of hot bitumen to incorporate the waste salts into the asphait. A schematic of this process is shown in Figure $4.3[4.6]$.

Thin film evaporator concentrate, which is powdery and contains a very small amount of moisture, falls by its own weight into the molten bitumen beneath it. The bitumen is kept at a suitable temperature $\left(200^{\circ} \mathrm{C}\right)$ to guarantee a low viscosity. As a result of the density difference, the waste solids settle in the mixture to a highly packed sediment of bitumen coated solids 


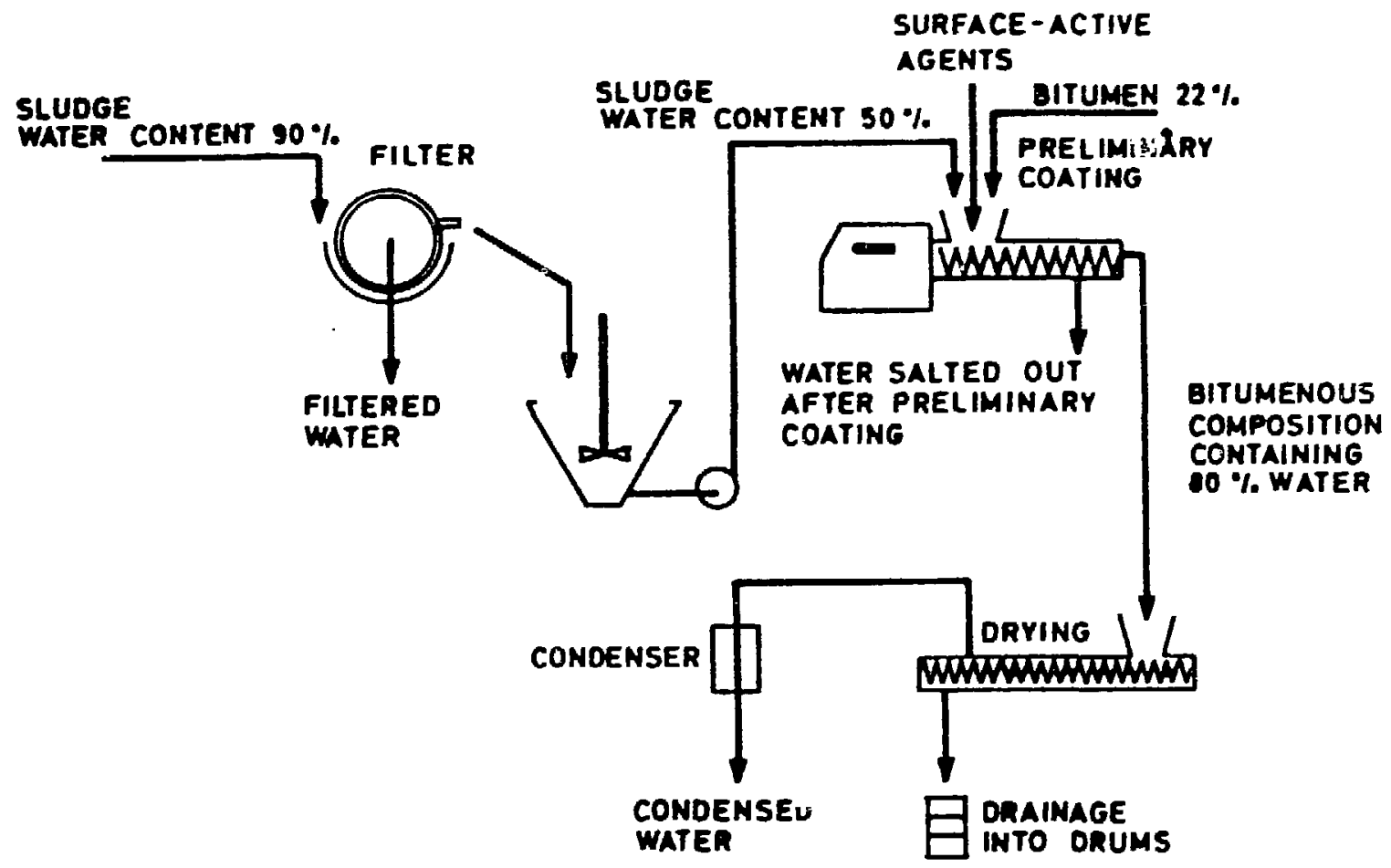

Figure 4.2. Schematic of the temporary emulsion process. 


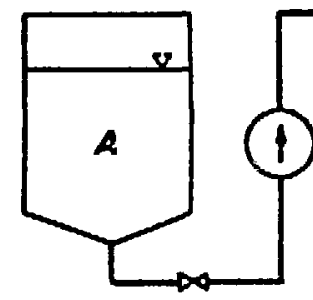

A ..... Concontrate solution storaoe tank

B ..... Thin film evaporatur

C $\quad$..... Heaterd bitumen storage tank

D ..... Vacuum pump

f..... Mixing vessel

F ..... Standard storage barrel

G $\quad$..... Vapour recondensator
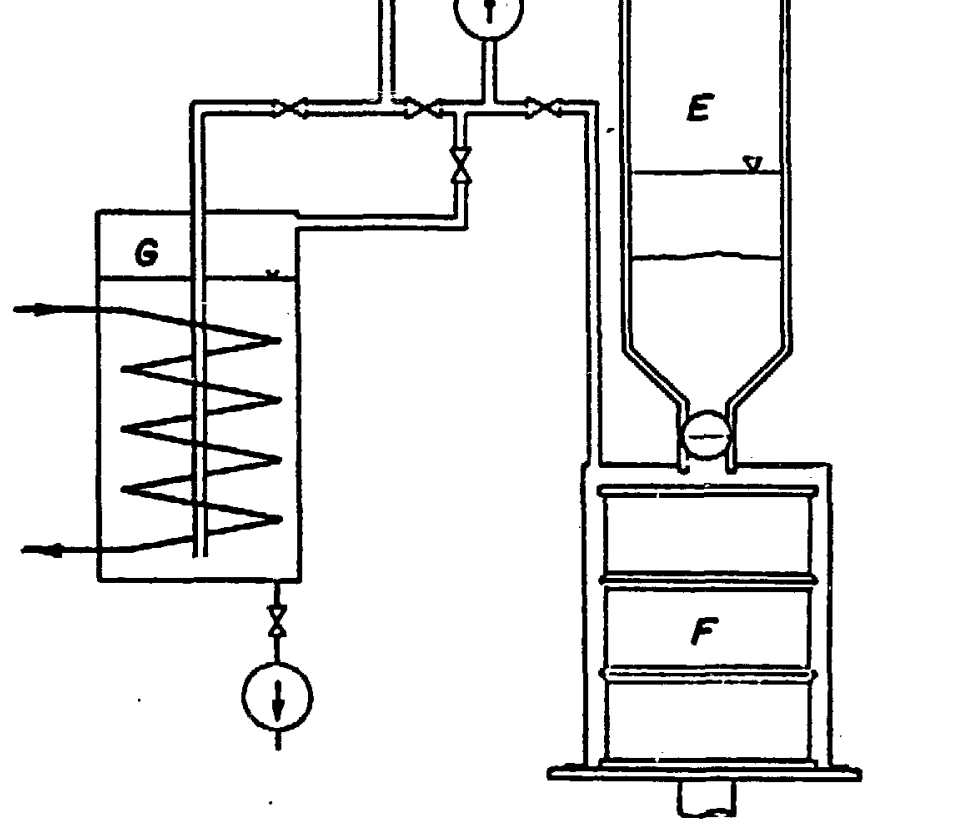

Figure 4.3. Schematic of the sedimentation process. 
which gradually fill the mixing vessel. When the mixing vessel is filled, the product is emptied into a storage barrel. The entire system, from the thin film evaporator to the storage barrel, is closed and maintained at reduced pressure. It is thereby possible to operate without any contamination of the environment [4.6].

A pilot plant which started operation in 1973 is able to process 25 kg per hour of concentrate solutions and precipitation sludge. The final product reaches a packing density of 50-70 wto salts in bitumen.

\subsubsection{Screw Extruder Process}

This system, marketed in the United States by Werner \& Pfleiderer Corporation, uses a twin-screw extruder of the type employed in the plastics industry. In this process, liquid bitumen $\left(140^{\circ} \mathrm{C}\right)$ and wet solid wastes are continuously pumped at predetermined rates into one end of the extruder. They are spread by screws into a thin film on the heated surface of the extruder barrel. Steam is employed for barrel heating. This mechanical processing at an elevated temperature of $170^{\circ} \mathrm{C}$ effects essentially complete evaporation of the water in the waste and provides homogeneous mixing of waste solids with bitumen. The evaporated distillate water is vented through large disengaging sections called steam domes which are drained to a condensate system. The bitumen-waste mixture is discharged from the extruder directly into solidification containers, where it is allowed to cool and solidify. Because the mixture shrinks on cooling, each container is normally filled, allowed to cool and then topped off to provide more camplete usage of its volume. A schematic of this process is shown in Figure 4.4 [4.7].

These screw extruders are available in various sizes, with barrel diameters typically $12 \mathrm{~cm}$. The processing rate depends upon the water content of the waste and the temperature at which the individual heating sections are 


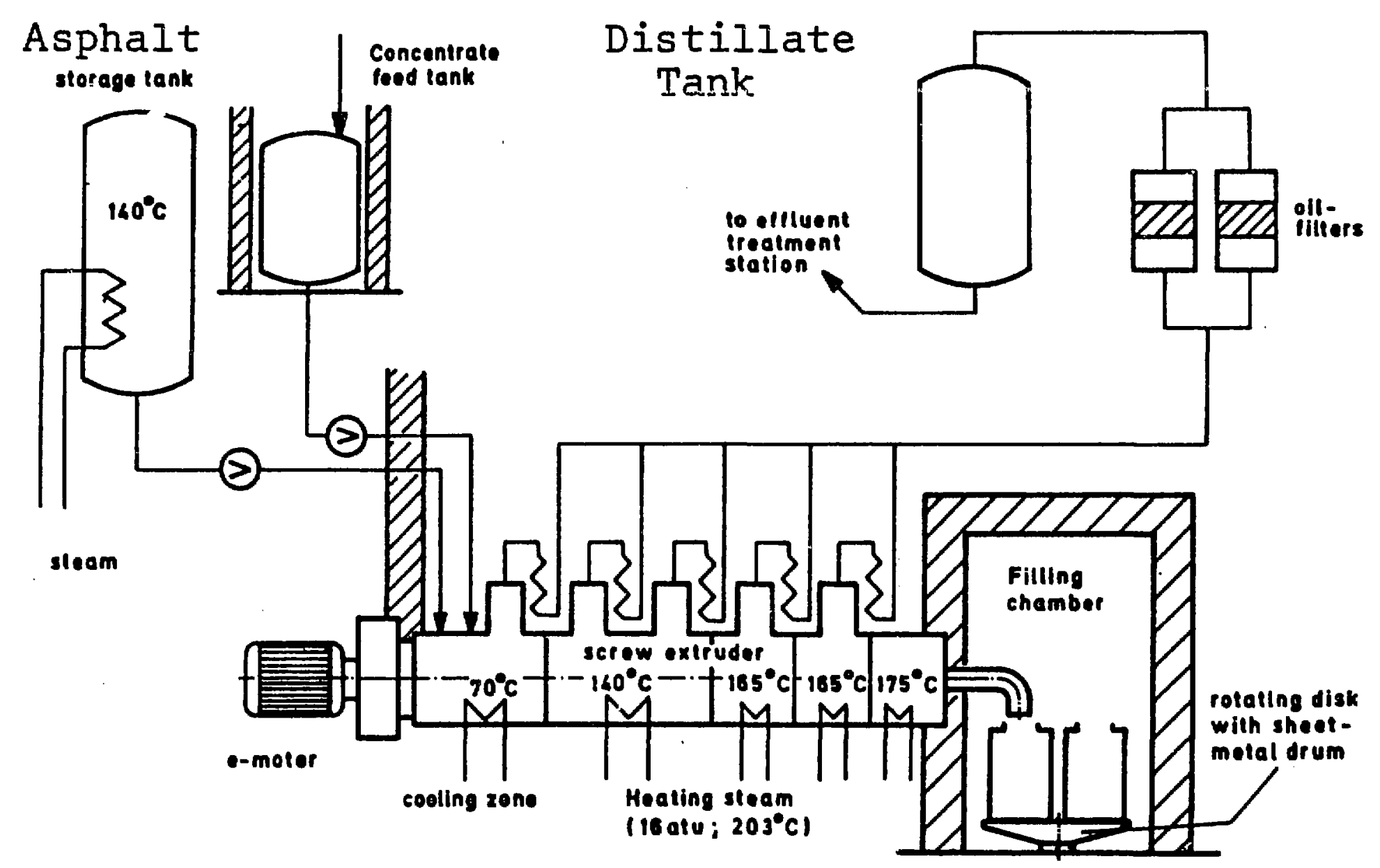

Figure 4.4. Schematic of the screw extruder system. 
operated. The waste and bitumen feed rates are controlled to provide a product of approximately 50 wtz waste solids.

\subsubsection{Emulsified Bitumen Process}

The emulsified bitumen process was developed at Oak Ridge National Laboratory to avoid a major criticism of other bitumen processes which is the heat required to melt the bitumen $[4.4,4.8,4.9]$. Heating presents two main difficulties: 1) the possibility of a fire, and 2) the high operating temperature may volatilize some constituents of the waste before they are solidified in the asphalt. In an effort to overcome these problens, enulsified asphalt, thich is fluid at room temperatures, was used. Both a batch process and a continuous process were developed. A pilot plant was commissioned around 1965.

The batch process consists of 1) adding the waste directly to emulsified asphalt in an evaporator tank initially operating at a temperature of up to $\sim 100^{\circ} \mathrm{C}$. The tank also contains a stirrer and a botton outlet rotating at a rate of about $100 \mathrm{rpm}, 2$ ) evaporating the water in the mixture by raising the temperature to $160^{\circ} \mathrm{C}$, and 3) draining the product into a disposal container. In the continuous process, the waste and asphalt are introduced at the top of a wiped film evaporator and the mixture flows down the walls of the evaporator operated at $160^{\circ} \mathrm{C}$. Agitator paddles sweep the walls continuously at about $300 \mathrm{rpm}$ and provide good mixing and heat transfer. The process was demonstrated on a laboratory scale with nonradioactive waste in a 4 inch diameter $\times 6$ inch high evaporator and on a pilot plant scale with a 12 inch diameter $\times 16$ inch high Pfaudler wiped film evaporator with a $4 \mathrm{ft}^{2}$ of heat transfer surface. The processing rate in the large unit was about $4 \mathrm{gal} / \mathrm{hr}$ of product containing 60 wto solids [4.8]. 
Waste form products containing from 20 to 80 wto waste solids have been prepared [4.8]. The bitumen was an emulsified asphalt used in the surface treatment of roads (type RS-2: a rapid setting, high viscosity, enulsified asphalt containing 63 wtz asphalt, 35 wto water, and 2 wto emulsifying agent). Products containing 20 to 60 wto waste solids flowed freely from the evaporator at $130^{\circ} \mathrm{C}$, whereas the product containing 80 wto solids was removed with difficulty at $195^{\circ} \mathrm{C}$. The product containing 60 wto waste solids represented a good compromise of properties, volume reduction, viscosty, and ductility [4.11].

\subsection{Bitumen Waste Form Characteristics}

The characteristics of bitumen waste forms which have received most attention are leachability and those related to the stability of the material under heat and radiation. Mechanical strength is a moot point since bitumen is thermoplastic. Viscosity, however, can be measured by penetraneter tests at defined temperatures. Most characteristics of bitumen are dependent on the type and amount of waste incorporated within the waste form, as well as the grade of bitumen utilized.

\subsubsection{Chemical Compatibility of Waste}

Table 4.2 indicates the chemical compatibility of typical wastes with bitumen. The chenical compatibility of specific wastes within the general classes indicated is dependent upon the exact chemical nature of the waste.

Solidification of ion exchange resins can present difficulties sirce the temperatures at which they begin to decompose are within the operating temperatures of the processes. This decomposition can generate gaseous byproducts which may be detrimental to the product. Decomposition may be avoided by minimizing the time during which resin wastes are exposed to high 


\section{TABLE 4.2}

Chemical Compatibility of Wastes With Bitumen

Waste Type

Ion exchange resins

Sludges

Boric acid wastes

Sulfate wastes

Nitrate wastes

Phosphate wastes

Carbonate wastes

Oils

Organic liquids

Acidic wastes

Alkaline wastes

Filter cartridges

Large items
Waste Compatibility

fair

$\operatorname{good}^{(a)}$

good

fair

poor

good

good

poor-fair

poor-fair

fair

fair

(b)

(b)

(a) Caution required with oxidizing sludges

(b) Processes generally not applicable to these wastes 
temperatures. Sulfate waste products have been observed to deteriorate rapidly upon immersion in water due to hydration of anhydrous sulfate salts. In addition, the incorporation of other salts, such as $\mathrm{NaNO}_{2}, \mathrm{MgCl}_{2}, \mathrm{Al}_{2}\left(\mathrm{SO}_{4}\right)_{3}$, $\mathrm{MgSO}_{4}$ and $\mathrm{NaAlO}_{2}$ can be detrimental to the bitumen itself. Nitrate and nitrite waste have been shown to accelerate burning of bitumen waste forms and to increase their hardness $[4.2,4.10]$. Addition of most waste solids to the bitumen will tend to elevate the flash point, while oxidizing wastes, particularly those that are volatile below the flash point of the bitumen used $\left(280^{\circ} \mathrm{C}\right)$, will tend to lower it. Some workers [4.2] have observed explosive ignition of bitumen waste forms loaded with 46 wto nitrate salt, but more recent tests trying to detonate such waste forms suggests that they are not explosive [4.2, 4.10]. Addition of organic liquid wastes will soften and tend to liquify the bitumen as increasing quantities are added. Filter cartridges and other large itens can be solidified with bitumen, however, must processes are not directly applicable to such wastes.

\subsubsection{Leachability}

Leach rates of bitumen waste forms have been shown to depend upon a complex interplay of a variety of factors, as is the case with most other solidification media. Figure 4.5 is a plot of the leach rate of a variety of constituents from an actual asphalt waste form [4.11]. The general form of the curves is due to an initial high leach rate of surficial contamination from the waste form. The first minima is due to reduced leaching through a hard coating that typically forms on an asphalt waste form. The remainder of the curve is the leach rate as it approaches the steady state condition [4.2] 


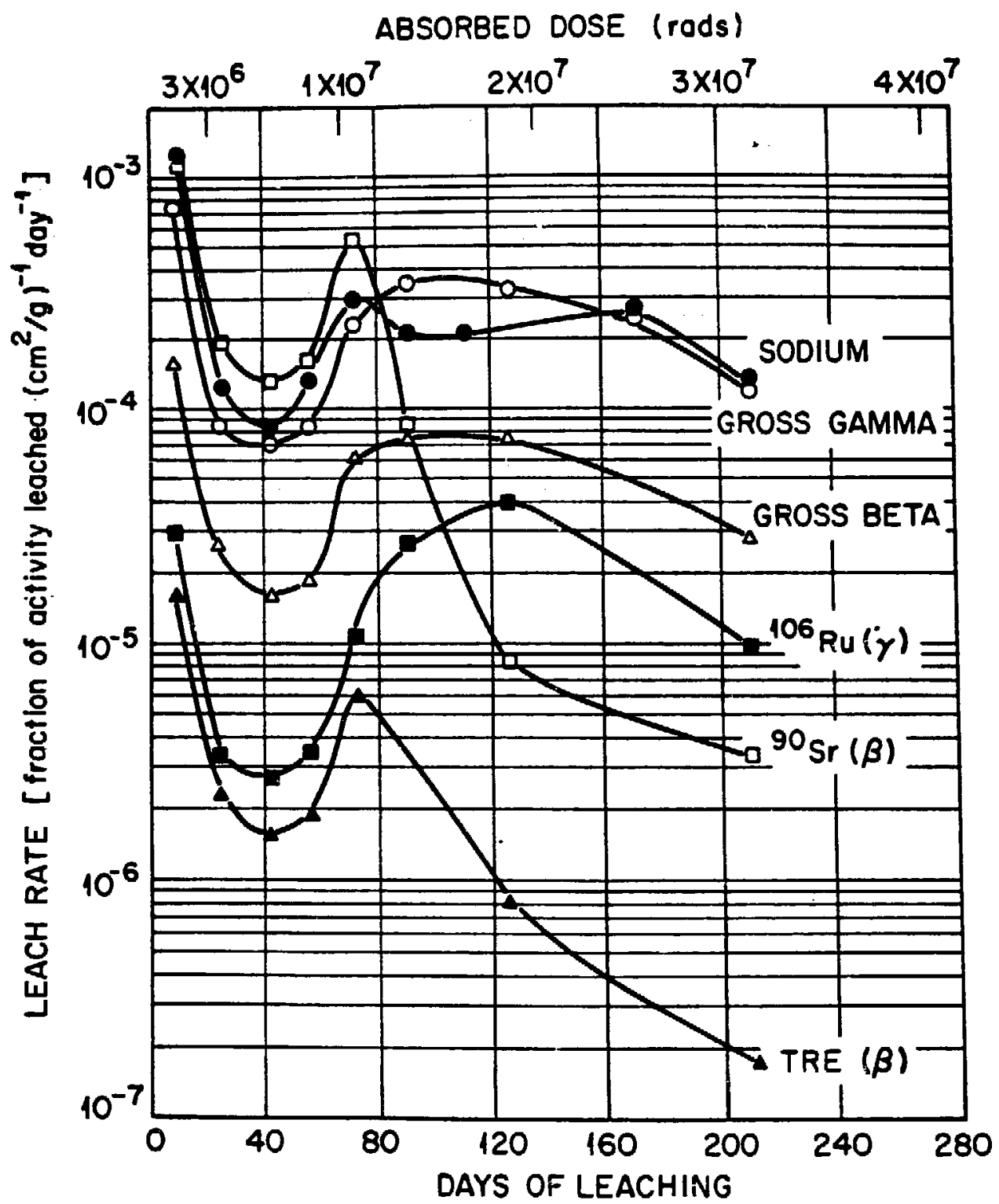

Figure 4.5. Leach rate curves for various constituents of a bitumen waste form. 
The leach rates for the different radionuclides shown differ by several orders of magnitude. Absorbed dosage shown at the top of the figure refers to internal self-irradiation of the waste form.

Leaching tests with distilled water show that the rates at which strontium, $\left(10^{-6} \mathrm{~g} /\left(\mathrm{cm}^{2}\right)(\right.$ day $)$, and ruthenium are leached from asphalt products containing nitrate wastes are low $[4.2,4.3]$. The leach rate for cesium is 50-100 times higher than this, but addition of grundite to the waste form provided a leach rate of $7 \times 10^{-5} \mathrm{~g} /\left(\mathrm{cm}^{2}\right)$ (day), half that of cesium without clay added.

Work in the Soviet Union has shown that the softer type (BN-III) asphalt is superior by 3 orders of magnitude, for preventing leaching of sodiun nitrate wastes, than the harder BN-IV [4.2] . Other workers, however, report somewhat less significant difference between asphalt iypes. Figure 4.6 shows leach rates for two dissimilar types of asphalt: Mexphalt 40/50 (distillation products) and Mexphalt R 90/40 (oxidized bitumen) and for two types of leachants [4.2]. The leachant differences are slightly more inportant than asphalt type, although none are large compared to differences seen among various radionuclides leached.

The type of waste and the relative proportion of it incorporated in the waste form are strong influences on leachability. Figure 4.7 shows the leach rates of ${ }^{137} \mathrm{Cs}$ from three types of waste incorporated in similar waste forms.

Leach rates are also influenced by the amount of waste incorporated in the product. Experiments at Oak Ridge National Laboratory using intermediate level waste forms with two different waste loadings, 20 waste solids and $60 \mathrm{wtz}$, gave steady state leach rates of $1.5 \times 10^{-4} \mathrm{~g} /\left(\mathrm{cm}^{2}\right)$ (day) and $3 \mathrm{x}$ $10^{-4} \mathrm{~g} /\left(\mathrm{cm}^{2}\right)$ (day), respectively [4.11]. 


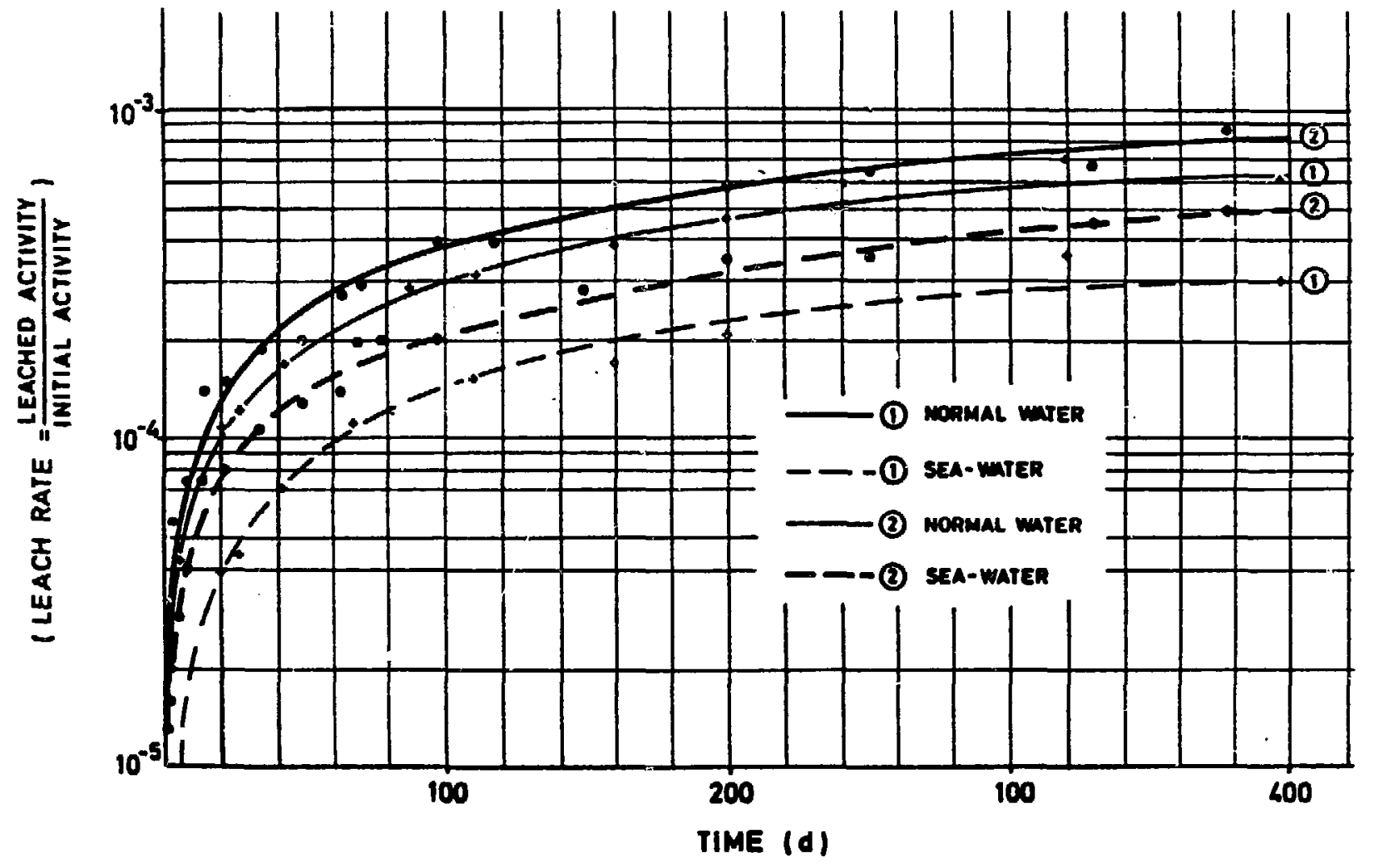

Figure 4.6. Leach rates from bitumen waste forms containing evaporator concentrates and $44 \%$ bitumen. 1 denotes mexphalt $40 / 30$ and 2 denotes mexphalt R 90/40. 


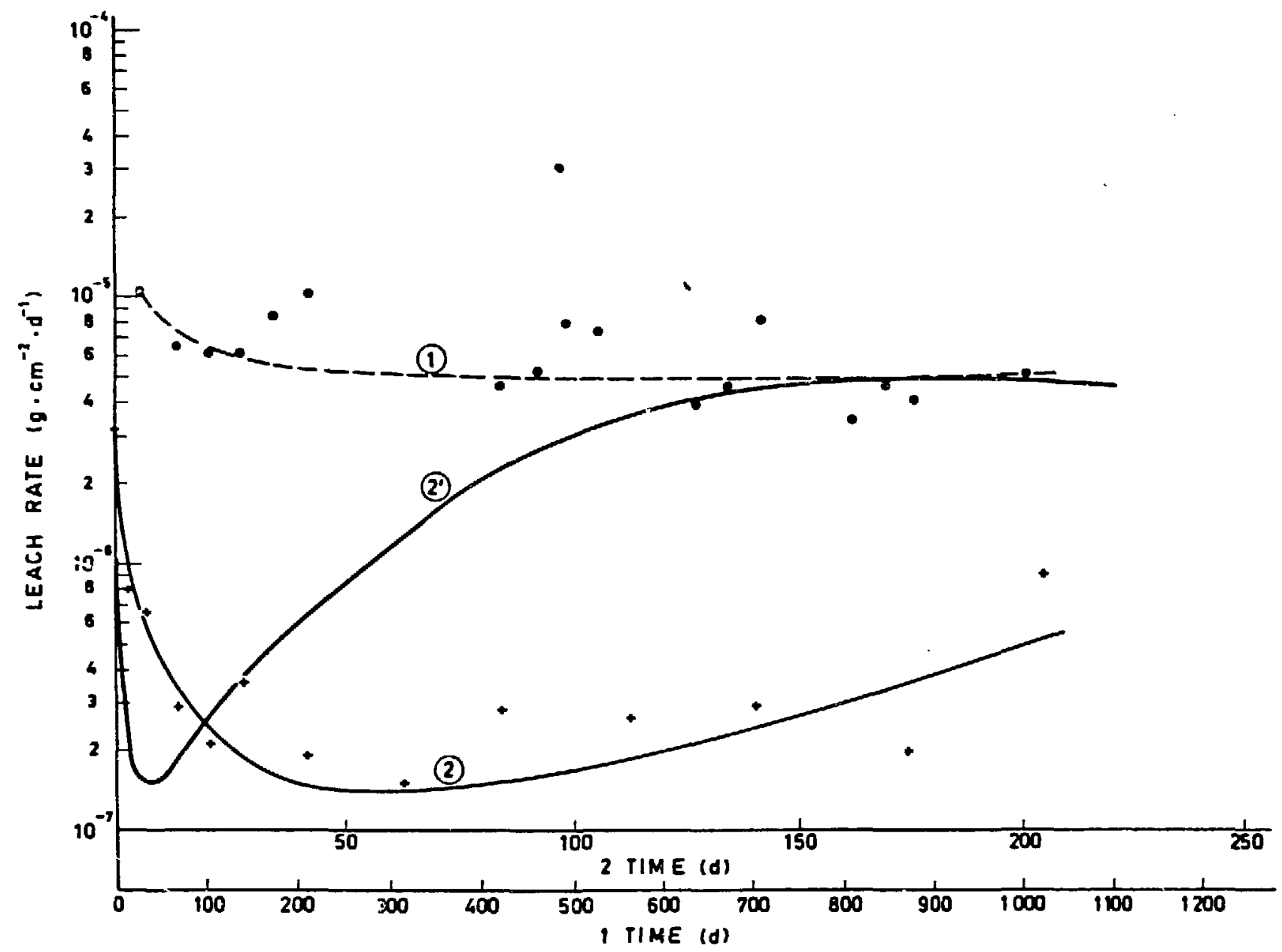

Figure 4.7. Leach Rate of ${ }^{137} \mathrm{Cs}$ from Bitumen BN-III containing: 1) $40 \%$ sodium nitrate, 2) $40 \%$ calcium it trate and 3) $40 \%$ calcium carbonate. 
The temperature at which ${ }^{90} \mathrm{Sr}$ bearing waste is mixed with asphal.t. can be important. With a $120^{\circ} \mathrm{C}$ processing temperature a steady state strontium leach rate of $10^{-5} \mathrm{~g} /\left(\mathrm{cm}^{2}\right)$ (day) was measured while with a $160^{\circ} \mathrm{C}$ processing temperature the leach rate was significantly lower $\left(<10^{-6} \mathrm{~g} /\left(\mathrm{cm}^{2}\right)\right.$ (day) [4.2]. This was ascribed to reactions, at higher temperatures, of strontium with the bitumen. Another process factor which can affect leach rate is the percentage of water which remains in the waste form after solidification. An 8 wto increase in initial water content (most bitumen samples will absorb sam: water during leaching) will result in more than an order of magnitude increase in the leach rate [4.2]. This may be related to the increased surface area exposed to leaching by pores filled with water in the waste form. As mentioned previously, leach rates from bitumen waste forms containing sulfate wastes can be very high due to the deterioration that results as the anhydrous sulfate waste solids absorb water and form hydrates.

\subsubsection{Mechanical Properties}

Since bitumen flows under pressure at ambient temperatures, normal compression and impact testing techniques cannot be directly appljiad. Howexrer, while bitumen will flow under pressure, it does not fail sy a fracture mechanism conmon to compression failures of non-thermplastic materiais. (Bitumen can be made to fail under compression at sub-ambient temperatures.) Similarly, bitumen does not tend to fracture and generate particulates under impact loadings at ambient temperatures. Tests are available to measure the resistance of bitumen to penetration. 


\subsubsection{Radiation Stability}

Products containing 60 wto solids of Oak Ridge intermediate and lowlevel waste were prepared using a hard-base as, shalt and ${ }^{60} \mathrm{Co}$ irradiated to doses of $10^{6}$ to $10^{8}$ rads. At a dose of $10^{6}$ rads, only negligible changes were observed. A dose of $10^{7}$ rads caused slight swelling, while a dose of $10^{8}$ rads caused a sample to swell about $36 \%$ in volume and a dose of $10^{9}$ rads caused a sample to swell 708 in volume. In contrast, similar samples prepared from a soft-base asphalt and irradiated to a dose of $10^{8}$ rads showed only a slight increase in volume. Presumably, gaseous products (if formed) were released by the softer material. The swelling observed in such studies may be dependent upon the dose rate. If gases are generated faster than they can diffuse from the bitumen product, swelling can result. However, in actual practice, dose rates and hence gas generation resulting from radiolysis may occur slowly. In addition to swelling, the samples became harder with increasing radiation dose. However, the samples that were irradiated to the highest doses were still pliable at room temperature [4.12]. The ef:ects of internal irradiation, up to $10^{8}$ rads, have been reported to be negligible [4.12]. External irradiation to the same dosage caused significant effects; however, the dose rate may be an important factor. Internal exposure required over 838 days to reach that level. In this time, the rate of g=r generation was apparently close to the ability of the bitumen to recombine or to release the gas. Thus, few gas bubbles and no swelling were observer.

\subsubsection{Thermal Properties}

A major concern with bitumen as a waste form matrix is the danger of iive both in the processing of the waste form and during subseguent interim 
storage, transportation and dispoal. Incorporation of inert solids into bitur men acts to elevate the flash point of the product [4.12]. However, solidification of wastes containing waste solids which are oxidants such as nitrate salts, may present a hazard. Tests have shown that BNR wastes in asphalt had a slightly higher flash point than did plain asphalt. The flame point and the softening point both increase with addition of nitrates. However, it was noted that the race of combustion also increased [4.2]. Exposure of bitumen waste forms to heat and consequent bitumen softening can also result in the settling of waste solids within the waste form or cause the waste form to flow.

\subsection{Advantages and Disadvantages}

Table 4.3 lists advantages and disadvantages of employing bitumen as a solidification agent for low-level radioactive waste. A major advantage associated with the use of bitumen in its potential for substantial volume reduction of aqueous wastes as a result of the evaporation of contained water occurring during the solidification process. 
TABLE 4.3

Advantages and Disadvantages of Bitumen Solidification

Advantages

1. Technology and material are well known and available

2. Compatible with a wide range of wastes

3. Concurrent volume reduction of aqueous wastes

4. No free standing water

5. Individual waste particles are coated

6. Low cost of bitumen

7. No difficulty with improper setting since it is not a chemical process

8. Typically low leachability
Disadvàntages

1. Bitumen is flammable and burns spontaneously at temperatures as iow as $390^{\circ} \mathrm{C}$

2. Limited loading of sajts due to hardening effects

3. May swell in water leading to increased leachability and product degradation

4. Potential for radiolytic gas generation

5. Exposure to heat may cause melting or phase separation of waste form

6. Process requires elevated temperatures

7. Heating must be well controlled and spread evenly

8. Storage of asphalt before use requires elevated temperatures to maintain fluidity of material

9. Capital equipment costs are relatively high

10. Generation of off-gas during processing oil evaporate may clog filters 
[4.1] Doyle, R. D., "Asphalt Encapsulation of Radioactive Waste," in Waste Management '79, R. G. Post, ed., PP. 531-542, 1979.

[4.2] IAEA, Bitumenization of Radioactive Wastes, Technical Report Series \#116, International Atonic Energy Agency, Vienna, Austria, 1970.

[4.3] Chemical Technical Division Annual Progress Report for-Period Ending May 31. 1967. ORNL-4145, Oak Ridge National Laboratory, Oak Ridge, TN, 1967.

[4.4] Chemical Technology Division Annual Progress Report for Period Ending May 31. 1968, ORNL-4272, Oak Ridge National Laboratory, Oak Ridge, TN, 1968.

[4.5] Burns, R. B. and Clare, G. W., Bitumen Incorporation - AERE Operational Experience, AERE-M2143, laboratory (AERE), Novenber 1968.

[4.6] Zegan, J., Knotik, K. and Jakusch, H., "Sedimentation Technique of Waste Bitumenization and Thermogravimetric Characteristics of the Final Products," in Management of Radioactive Wastes from the Nuclear Fuel Cvcle, Vienna, IAEA-SM-207/87, International Atomic Energy Aency, Vienna, Austria, p. 113, 1976.

[4.7] Werner and Pfleiderer Corporation, Topical Report Radwaste Volume Reduction and Solidification System, Report No. WFC-VRS-1, Werner and Pfleiderer Corporation, Waldwick, NJ, 1976.

[4.8] Blanco et al., Recent Develogments in Treating Low- and IntermediateLevel Radioactive Waste in the United States, ORNI-TM-1289, Oak Ridge National Latoratory, Oak Ridge, TN, 1965.

[4.9] Chemical Technology Division Annual Report for Period Ending May 31 , 1966, ORNL-3945, Oak Ridge National Laboratory, Oak Ridge, TN, 1966.

[4.10] Colombo, P. and Neilson, R. M., Jr., Critical Rexiew of the properties of Solidified Radioactive Waste Packages Generated at Nuclear Power Stations, BNI-NUREG-50591, Brookhaven National Laboratory, Upton, NY, 1976.

[4.11] Burns, R. H., Solidification of Low and Intermediate-Level Waste, Atomic Energy Review 2 (3), P. 5471971.

[4.12] Godbee, H. W., Goode, J. H. and Blanco, R. E., "Development of a Process for Incorporation of Radioactive Waste Solutions and Slurries in Emulsified Asphalt, " Environmental Science and Technology, pp. 1034-1040, 1968. 
5. POLYETHYLENE AS AN AGENT FOR LOW-LEVEE WASTE SOLIDIFICATION

Use of the thermoplastic polymer polyethylene as a binder for low-level radioactive waste has been limited. Most experimental work was performed by Cak Ridge National Laboratory in conjunction with their bitumen studies.

\subsection{Description of Polyethylene}

polyethylene is a lightweight thermoplastic of the chemical formula $\left(\mathrm{CH}_{2} \mathrm{CH}_{2}\right) \mathrm{x}$. While the properties of polyethylene vary significantly, dependent largely upon chain length and density, same chemical properties of polyethylene lend themselves to the solidification of low-level radioactive waste. Polyethylenes are highly resistant to degradation by many chemicals, with the exception of free halogens, oxidizing acids and some ketones [5.1]. Polyethylenes are highly resistant to attack by water. However, stress cracks may develop if polyethylene is subjected to multiaxial stresses in contact with some polar liquids, such as metallic soaps, organic esters, liquid hydrocarbons and silicone fluids.

\subsection{Types of polyethylenes}

While polyethylenes are chemically all the polymerization products of ethylene, there are some differences in the properties of various types. High density polyethylenes (specific gravity $0.945-0,965$ ) are the products of a low pressure process, producing a linear, more crystalline molecular structure, which is -alatively strong and corrosion resistant. Low density pc.lyethylenes (specific gravity 0.915-0.925) are the product of a high pressure polymerization process and have lower strengths and reiuced resistance to chemical attack. Typical high density polyethylene has a softening point of about $127^{\circ} \mathrm{C}$, while the low density material softens at about $86^{\circ} \mathrm{C}$. A broad range of 
polyethylene procucts are available which are mixtures of the two types or have other olefin type plastics added to adjust their properties [5.1].

\subsection{Additives}

Some additives are available which may be used to improve certain characteristics of polyethylene. Because the plastic is subject to attack by ultraviolet light, carbon black may be added to block these effects. Similarly, antioxidants may be used. This is not typically viewed as significant for waste disposal applications. Resistance to stress cracking may be improved by adding polyisobutylene. Additives for decreasing leachability can be incorporated as was described for bitumen. However, no significant efforts in this area have been identified.

\subsection{Solidification Processes Osing Polyethylene}

The processes employed to sclidify radioactive waste with polyethylene use either screw extruders or wiped film evaporators. These processes are virtually identical to those used for bitumen. Other bitumen type processes could potentially be employed for use with polythylene.

\subsubsection{Wiped Film Evaporators}

In experiments at Oak Ridge National Laboratory, [5.2] 100g batches of polyethylene were processed in a wiped film evaporator operated at tempaatures of $100-170^{\circ} \mathrm{C}$. The evaporator was revolved at 100-300 $\mathrm{rpm}$ and a waste feed rate of between 1 and $3 \mathrm{ml} / \mathrm{min}$ employed, depending on the solids concentration. Evaporation took place at about the same speed as the feed rate. 
Evaporate concentrates and sodium borate wastes in concentrations of 20-40 wt: were satisfactorily prepared using polyethylene, although 40 wt: loading was the maximum (compared to about 60 wto loading for asphalts). Organic tributyl-phosphate (IBP) wastes were incorporated in polyethylene at loadings of 20-50 wto MBP. A good product was obtained with loads of 30 wtz TBP in DYLT polyethylene (Eastman Rodak Company). At higher concentrations same bleeding of IBP occurred. No acceptable waste form could be produced in these studies using asphalt (with fillers) and TBP waste.

\subsubsection{Screw Extruder}

A twin helical screw extruder has been used at the Japan Atomic Energy Research Institute to solidify spent ion exchange resins in polyethylene. Loadings of 50 wto were achieved with good results [5.3]. Apparently one power plant in The Netherlands has used a screw extruder to produce polyethylene waste forms.

\subsection{Polyethylene Waste Form Characteristics}

\subsubsection{Chemical Compatibility of Wastes}

Polyethylene is compatible with a variety of waste components, more so than many other solidification agents. Workers at Oak Ridge National Laboratory report that polyethylene was acceptable for all types of waste tested except oxidizing acids. Polyethylene acconmodated 30-40 wt: organic solvents, while asphalt could incorporate only 25 wtz. Typical maximum loadings of inorganic solids was about 40 wtz. Actual practice using polyethylene for lowlevel waste solidification is limited. 


\subsubsection{Leachability}

A few studies concerning the leachability of polyethylene waste forms have been conducted. Data are available for leach rates of sodium, ${ }^{106} \mathrm{Ru}$ and ${ }^{137} \mathrm{Cs}$. Figure 5.1 shows fraction release curves for sodium from waste forms containing varying amounts of $\mathrm{NaBO}_{2}$ and two types of polyethylene products, DYDr and DYLT (Eastman Rodak Co.) (Bakelite folyethylene resins, Union Carbide Plastic Co) [5.2]. Significant differences are reported for the different types of polyethylene matrix materials. Polyethylene waste forms containing 30 wtz tributyl phosphate and $0.1 \mu \mathrm{Ci} / \mathrm{ml}{ }^{106} \mathrm{Ru}$ had a leach rate of $1.5 \times 10^{-6} \mathrm{~g} /\left(\mathrm{cm}^{2}\right)$ (day) [5.2]. The cumulative fraction release of ${ }^{137} \mathrm{Cs}$ from io exchange resin solidified in polyethylene was as low as 0.18 after one year [5.3].

\subsubsection{Mechanical_Strength}

Because polyethylene is a thermoplastic material, its mechanical strength is best measured as a function of fluidity at a given temperat'mre. However, a uniaxial compressive strength of approximately $300 \mathrm{~kg} / \mathrm{cm}^{2}$ was reported for a waste form containing 50-60 wto ion exchange resin [5.4]. After exposure to garma irradiation to a dose of $10^{8} \mathrm{R}$, a $33 \%$ drop in compressive strength was observed.

\subsubsection{Radiation Stability}

Radiation stability tests at Oak Ridge National Laboratory using a ${ }^{60} \mathrm{Co}$ source indicated that an external dose of $10^{6} \mathrm{R}$ caused no damage. Doses of $10^{7}$ to $10^{9} \mathrm{R}$ caused some slight shrinkage and discoloration. No significant gas generation was observed. Others [5.1] report that when polyethylene is irradiated, hydrogen and smaller volumes of methane, ethane and propane are produced [5.1]. Irradiation induces crosslinking within the polyethylene 


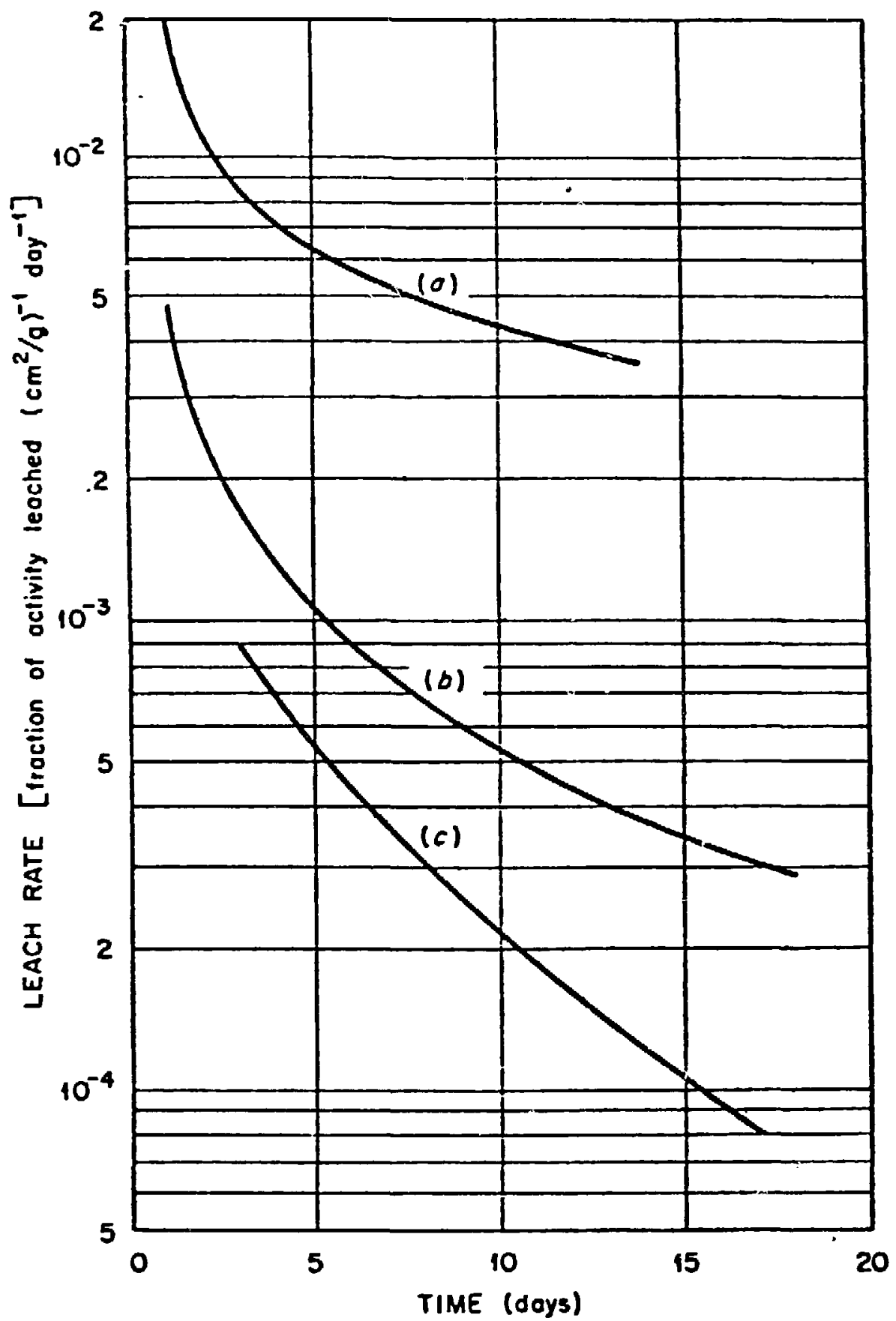

Figure 5.1. Results of leaching polyethelene waste forms in Water: a) $\mathrm{Na}$ from $40 \% \mathrm{NaBO}_{2}-60 \%$ DYDT, b) $\mathrm{Na}$ from $40 \% \mathrm{NaBO}_{2}-60 \%$ DYLT and c) $\mathrm{Na}$ from $20 \% \mathrm{NaBO}_{2}-80 \%$ DYLT $i 1$ lustrating differences in leaching from two types of polyethelene. 
which decreases its solubility, and induces brittleness. In essence, irradiation causes it to become also a themosetting plastic. Irradiation also causes color changes in which the material first yellows and with additional exposure turns dark red.

\subsubsection{Thermai Properties}

Polyethylene waste forms are flammable. A waste form containing 40 wtz nitrate salts ignited spontaneously at $440^{\circ} \mathrm{C}$ burning with a steady, yellow flame [5.2, 5.3]. A similar test with bitumen resulted in vigorous burning. Polyethylene itself does not spontaneously ignite upon heating to a temperature of $550^{\circ} \mathrm{C}$. However, exposure to temperatures of greater than $300^{\circ} \mathrm{C}$ oxidizes the material.

\subsection{Advantages and Disadvantages}

No table is presented for the advantages and disadvantages of polyethylene because of the paucity of information available for the use of this material as a solidification agent. The advantages/disadvantages are expected to be generally similar to those identified for bitumen. However, the cost of polyethylene is considerably higher than bitumen. 
[5.1] Miles, D. C. and Briston, J. H., Rolymer Technology, Chemical Publishing Co., Inc., New York, 1979.

[5.2] Fitzgerald, C. L., Godbee, H. W. and Blanco, R. E., "The Feasibility of Incorporating Radioactive Wastes in Asphalt or Polyethylene, Nuclear Aoplications and Technolocy, 2 (12) 1970.

[5.3] Miyanoga, I., Sakata, S., Ito, A. and Amano, H., "Development of Radioactive Waste Management at the Japan Atomic Energy Research Institute," in Nuclear power and Its Fuel Cycle, (Vol. 4), IAER-CN-36/156, International Atomic Energy Agency, Vienna, Austria, 1977.

[5.4] Chemical Rechnology Division Annual Progress Report for Period Ending May 31, 1968, ORNL-4272, Oak Ridge National Laboratory, Oak Ridge, TN, 1968. 


\section{UREA-FORMALDEHYDE RESIN AS AN AGENT FOR LOW-LEVEY WASTE}

SOLIDIFICATION

Urea-formaldehyde (UF) is a thermosetting polymer which has been widely used in various industries as adhesives, molding compounds and grouts to seal loose soils [6.1, 6.2]. In 1972 Protective Packaging, Inc. (Louisville, KY), began marketing its urea-formaldehyde system for solidifying radioactive wastes [6.1]. A variety of vendors have since developed IJF processes both as permanent installations and as mobile systems. Urea-formaldehyde systems have been used extensively in the nuclear elecric power industry. Urea-formalchehyde gained rapid acceptance in the industry as a result of its process advantages over the cement systems in use at that time. For example, there is no dusting problem, mixing is easy and rapid, mixers are readily cleanable and the equipment is relatively simple, inexpensive and has a small space requirement. In recent years, free-standing water problems with the waste form product have limited of the use of urea-formaldehyde and have, in fact, led to movement away from UF systems.

\subsection{Description of Urea-Formaldehyde}

Urea-formaldehyde, in the form used for low-level radioactive waste solidification, is an aqueous enulsion of 65 wtz partially polymerized monomethylol urea $\left(\mathrm{NH}_{2} \cdot \mathrm{CO} \cdot \mathrm{NH} \cdot \mathrm{CH}_{2} \mathrm{OH}\right)$ and dimethylol urea $\left(\mathrm{CH}_{2} \mathrm{OH} \cdot \mathrm{NH} \cdot \mathrm{CO} \cdot \mathrm{NH} \cdot \mathrm{CH}_{2} \mathrm{OH}\right)$ solids in water [6.3]. Crosslink polymerization occurs when 2-3 volume $z$ of a weak acid catalyst such as ammonium sulphate, sodium bisulphate or phosphoric acid is added to the ITF resin waste. Generally two parts of waste are adred to one part UF resin by volume, giving a volume efficiency (ratio of inqut waste volume to solidified waste volume) of $0.75[6.2]$. The solidification reaction is both $\mathrm{pH}$ and temperature dependent, with a preferred $\mathrm{pH}$ of 
$1.5 \pm 0.5[6.3]$. Gelling begins within a few minutes of the catalyst addition and a free-standing solid will generally be formed with 30 minutes. Complete polymerization requires several hours or days of curing [6.4]. The liquid waste $\mathrm{mi} . .$. in the urea-formaldehyde is not chemically reacted with the solidification matrix; rather it is entrapped in the polymer as small, discrete parcels of water. This encapsulated water is weakly acidic, noderately corrosive, and may be subject to some evaporation from the waste form $[6.1,6.2]$. Solids in the waste are mechanically held by the matrix. In order to prevent rapid corrosion of the canister, a protective coating or lining must be used. Urea-formaldehyde resin has a limited shelf life of several montis to a year. Shelf life is strongly dependent on temperature. Aged resin may result in poor solidification, producing a "cottage cheese" like waste form. This condition may also be caused by iow temperatures during the solidification reaction.

\subsection{Additives}

In other uses, wood flour and bleached wood pulp icellulose) are added to urea-formaldehyde resins to improve the strength of the solid [6.1]. As with cement, various clay minerals can be used to aid in the retention of particular radionuclides, especially cesium and strontium. Portland cenent is sometimes added to che waste container, after the urea-tormaldehyde has solidified, in order to bind any free-standing water present after solidification [6.1]. Other macerials, such as plasticizers, could be used to modify the characteristics of the solid.

\subsection{Solidificseion Processes Using urea-formaldehyde}

Differences in urea-formaldehyde processes of mixing the waste, UF resin, and finally the catalyst. Thorough mixing is 
regarded as crucial for proper solidification of waste forms because the low viscosity of the UF resin would otherwise allow differential settling of solids. As with cement, both in-container and in-line mixing processes are available. The in-container processes are best suited to incorporate resin beads into the waste form, while in-lining mixing is better suited for liquid wastes $[5.5]$.

\subsubsection{In-container Mixing}

In-container mixing is carried out in standard 55 gallon drums, or more commonly, in large carbon steel liners with volumes of 50-300 cubic feet. Mixing may be accomplished by a disposable paddle which is lowered into a drum, spun as the components are added (catalyst last), and then left in the solidifying mass. Another approach is to place a disposable air sparger at the botton of the container and, as the components are added, to pump air through the sparger piping. Small holes in the pipe allow air to bubble up, mixing the liquid. The sparger is also left in the waste form.

In-container systems are provided industrially as both installed and portable units. Portable units are operated by Chem-Nuclear Systens, Inc. (CNSI) and by Hittman Nuclear and Development Corporation (HNDC) [6.6] . These systems are built into a housing that is easily transportable by truck and can couple to the waste storage system of the plant. Mobile systems of this type appear to have gained in popularity among the nuclear power industry for a variety of reascns. Among these are: production of waste either beyond the capacity of the installed system at the plant, lack of an instailed system, or inoperative/unsuitable installed system [6.5] . 


\subsubsection{In-line Mixing}

In-line mixing of urea-formaldehyde is a process that is similar to that of cement, although the equipment requirements are considerably simpler because the UF is a low viscosity liquid [6.5]. The principal difference between the cement and UF system is the type of mixer used. UF can be blended with waste in a static mixer which contains no moving parts; the two fluids are mixed as they flow past stationary blades. Figure 6.1 shows a flow chart for an in-line continuous mixer system of United Nuclear Industries. Note that the catalyst is added last in order to allow time for complete mixing and prevent solidification in the process equipment. Once it is added, the waste form should start to gel within a few minutes.

\subsection{Urea-Formaldehyde Waste Form Characterization}

\subsubsection{Chemical Compatibility of Wastes}

The chemical compatibility of generic waste types with urea-formaldehyde is shown in Table 6.1. Sulfate wastes, such as those generated by regeneration of ion exchange resin wastes, can interfere with urea-formaldehyde polymerization. The incorporation of less than 10 wto sulfate in the final product or the addition of calcium chloride to the wasta has been reported to reduce this problem [6.4]. Difficulties have been encountered for the solidification of detergent solutions and complexing agent wastes, as well as with oils and organic liquids which are not miscible with water. Alkaline wastes can be solidified, but only after they have been pretreated to adjust pH (and hence at reduced efficiency). 


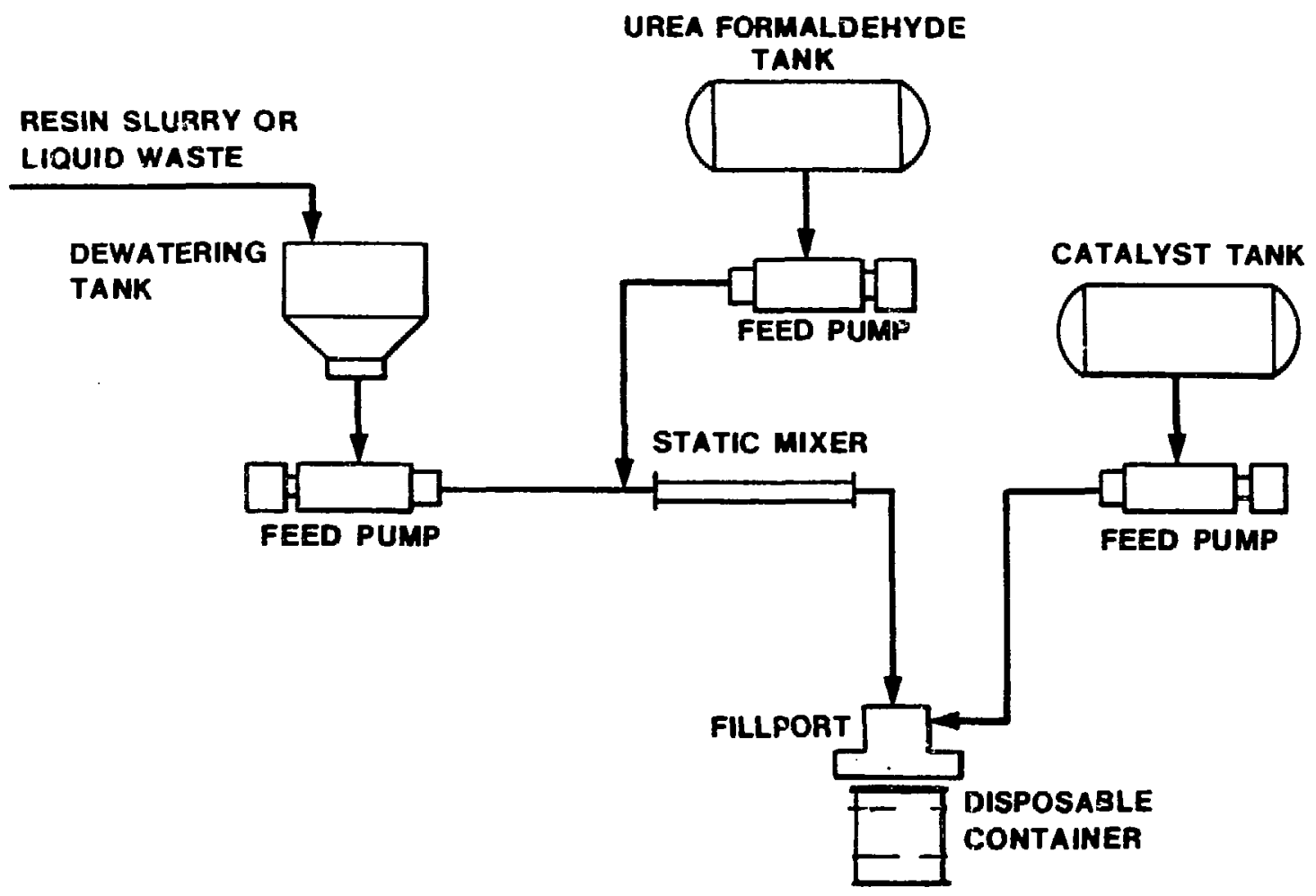

Figure 6.1. Schematic of an in-line urea-formaldehyde system by UNI. 


\subsubsection{Free-Standing Water}

As mentioned previously, urea formaldehyde gained rapid acceptance primarily as a result of the processing advantages it presented over competing cement systems. The resultant urea-formaldehyde waste form aiso met existing solidification requirements. However, problems have been encountered with unsolidified liquids, so-called free-standing water. Free-standing water in UF waste forms is typically acidic and corrosive toward the waste container.

\section{TABLE 6.1}

Chemical Compatibility of Wastes with Urea-Formaldehyde

Urea-Formaldehyde

Waste Type

Ion exchange resins

Sludges

Boric acid wastes

Sulfate wastes

Detergent solutions

Complexing agent wastes

Oils

Organic liquids

Acidic wastes

Alkaline wastes

Large items
Waste compatibility

good

$\operatorname{good}(a)$

good

poor-fair

poor

poor

poor

poor

good

poor-fair (b)

good

(a) good if $\mathrm{pH}$ is well controlled

(b) require treatment to adjust $\mathrm{pH}$ 
Urea-formaldehyde waste forms retain liquid wastes as small droplets physically held within the solidified matrix. However, after the waste form has soilidified there is often a significant amount of drainable free-standing water. This is water and waste liquids that are not bound either chemically or physically in the solidification matrix. While the majority of this water typically comes from the waste itself, same additional water is produced as a result of the condensation polymerization reaction that occurs during solidification. Free-standing water may increase in volume with time. A complex relationship between the percentage of free-standing water and the $\mathrm{B}_{2} \mathrm{O} / \mathrm{UF}$ ratio was observed, as shown in Figure 6.2, which is also related to shrinkage of the waste form [6:4]. High percentages (as much as 26\%) of free-standing water were observed for the solidification of same wastes in urea-formaldehyde. The quantity of free standing water is generally minimized by the addition of sufficient acid catalyst to produce a UF-waste mixture pH of $1.5 \pm 0.5$ [6.4]. Among the factors affecting the generation of freestanding water are: the percentage of water in the waste and percentage of waste in the matrix, type of waste, and the amount of catalyst used.

The free-standing water is acidic with a pH approximately equal to that of the UF-waste mixture after acid catalyst addition ( $\mathrm{pH} \sim 2$ ). The activity content and concentration in the free-standing water is typically the same as that in the input waste stream. General corrosion rates as high as 10 mil/year were observed for exposure of mild steel to free-standing water [6.4]. Both general and non-uniform (pitting) corrosion occurred. The rate was dependent upon the waste type. Corrosion in contact with a urea-formaldehyde waste form was typically lower. 


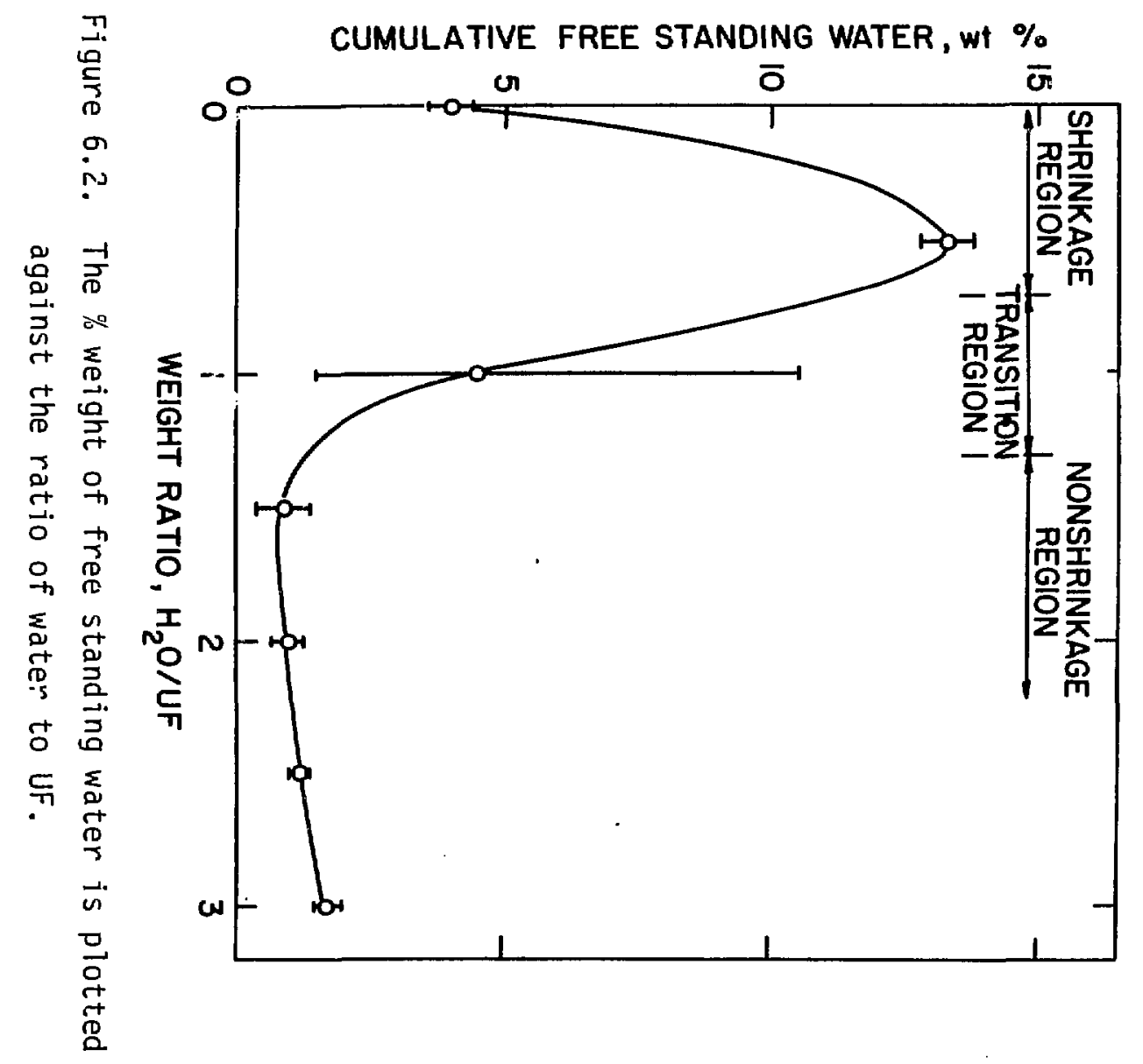




\subsubsection{Leachability}

Cumulative fraction releases for leach tests performed on $(2.5 \mathrm{~cm}$ diameter $\times 5.1 \mathrm{~cm}$ ) urea-formaldehyde waste forms are shown in Figure 6.3 for ${ }^{60} \mathrm{Co},{ }^{85} \mathrm{Sr}$ and ${ }^{137} \mathrm{Cs}[6.6]$.

The leach rates, are typically reported to vary from $10^{-1}$ to $10^{-2}$ $\mathrm{g} /\left(\mathrm{cm}^{2}\right)$ (day) $[6.2,6.4]$. These rates are generally higher than those measured for other types of waste forms. As with other binders, the leach rate varies for different nuclides. The type of leachant also affects the leach rate. Figure 6.4 illustrates the differences in cumulative fraction release from a UF waste form using saltwater, distilled water and tapwater leachants. The differences here are similar to the differences observed among nuclides leached. The waste type and waste/UF ratio also affect the leach rates.

While proprietary additives have been reported as effective in decreasing leachability, this has not been confirmed. Such additives are not in routine use for LIW solidification. Leach rates were not influenced by the mechanical strength of the samples [6.7].

Gamma irradiation also increases waste form leachabiltiy as shown in Figures 6.5 and 6.6 for release of ${ }^{137} \mathrm{Cs}$ and ${ }^{85} \mathrm{Sr}$ respectively. The threshhold of this effect appears to be about $10^{6}$ rads.

\subsubsection{Mechanical_Strength}

Compressive strengths of urea-formaldehyde waste forms are dependent on the type of waste incorporated and the waste/UF ratio. Density has little effect. Compressive strengths ranged from $61 \pm 22$ psi to $387 \pm 53$ psi for a range of reactor waste types [6.4]. The highest strengths were achieved with BWR precoat filter cakes. Typically, urea-fomaldehyde resin alone has a strength of about 700 psi. Prolonged drying also reduces the strength of the waste form [6.7]. The impact strength of UF waste forms varies depending upon 


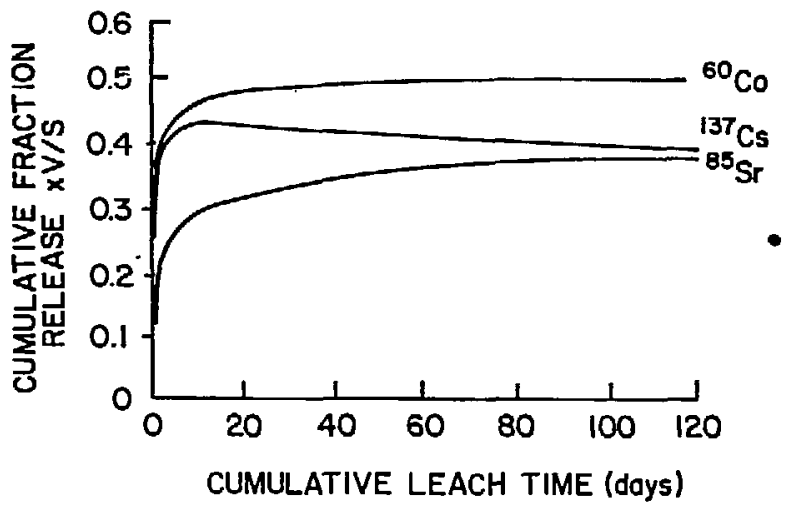

Figure 6.3. Cumulative fraction releases for ${ }^{60} \mathrm{Co},{ }^{85} \mathrm{Sr}$ and ${ }^{137}$ Cs from UF waste forms.

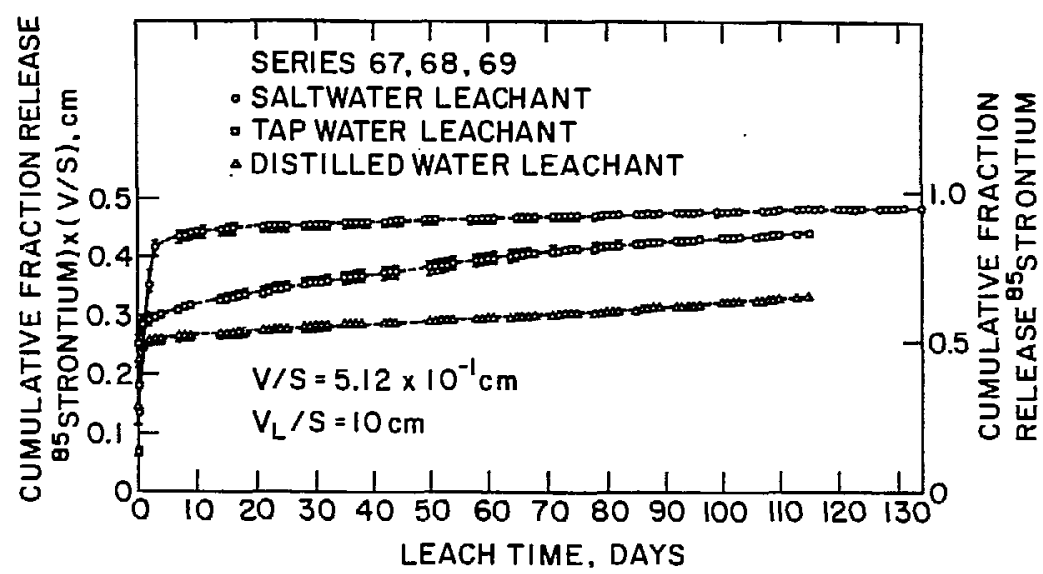

Figure 6.4. Cumulative fraction release for ${ }^{85} \mathrm{Sr}$ with varying leachants. 


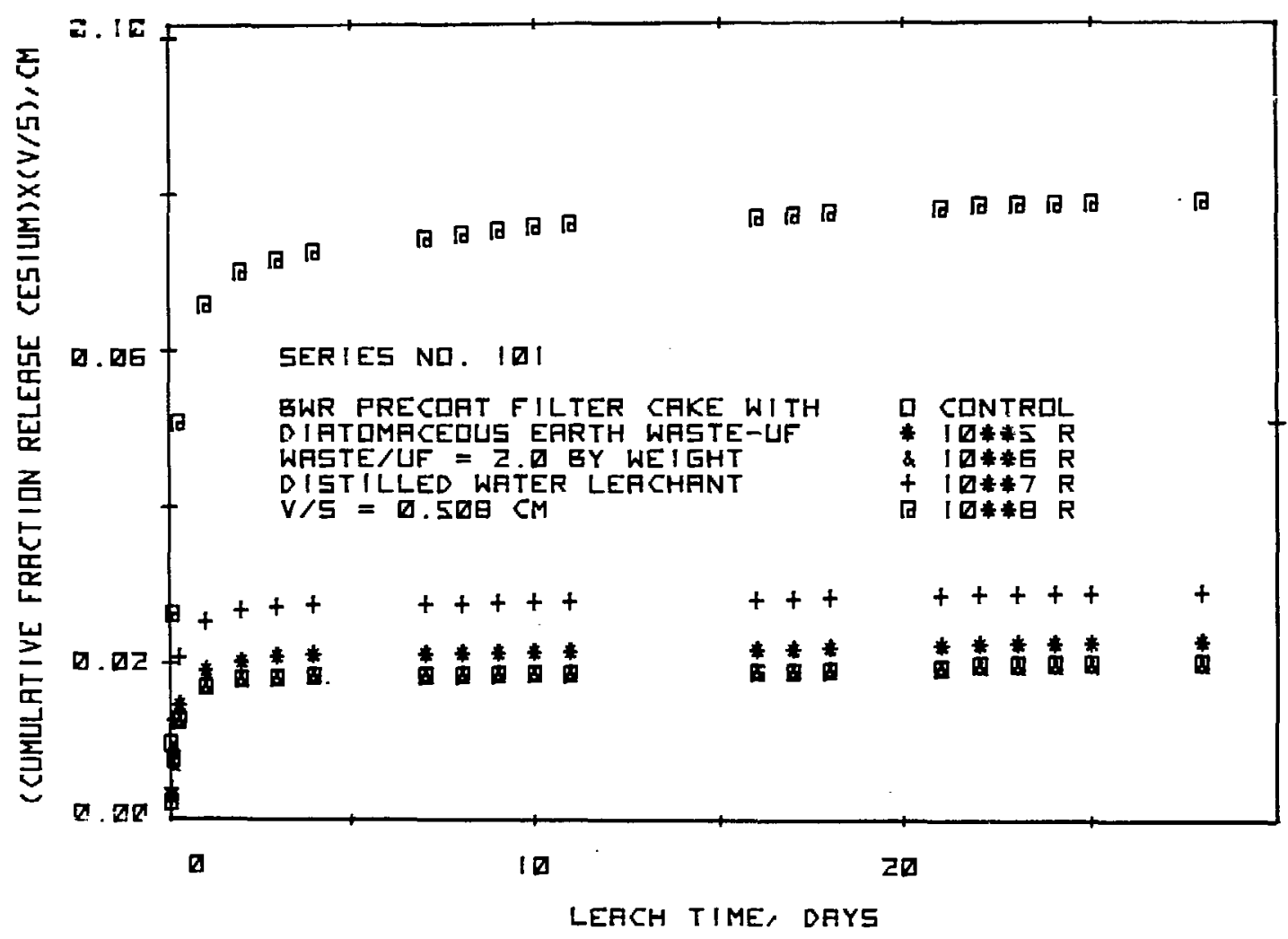

ロ. Z

Figure 6.5. The effect of varying doses of ${ }^{60}$ Co irradiation of the leachability of ${ }^{137} \mathrm{Cs}$. 


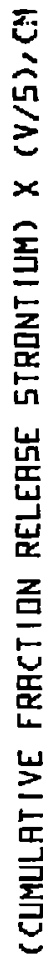

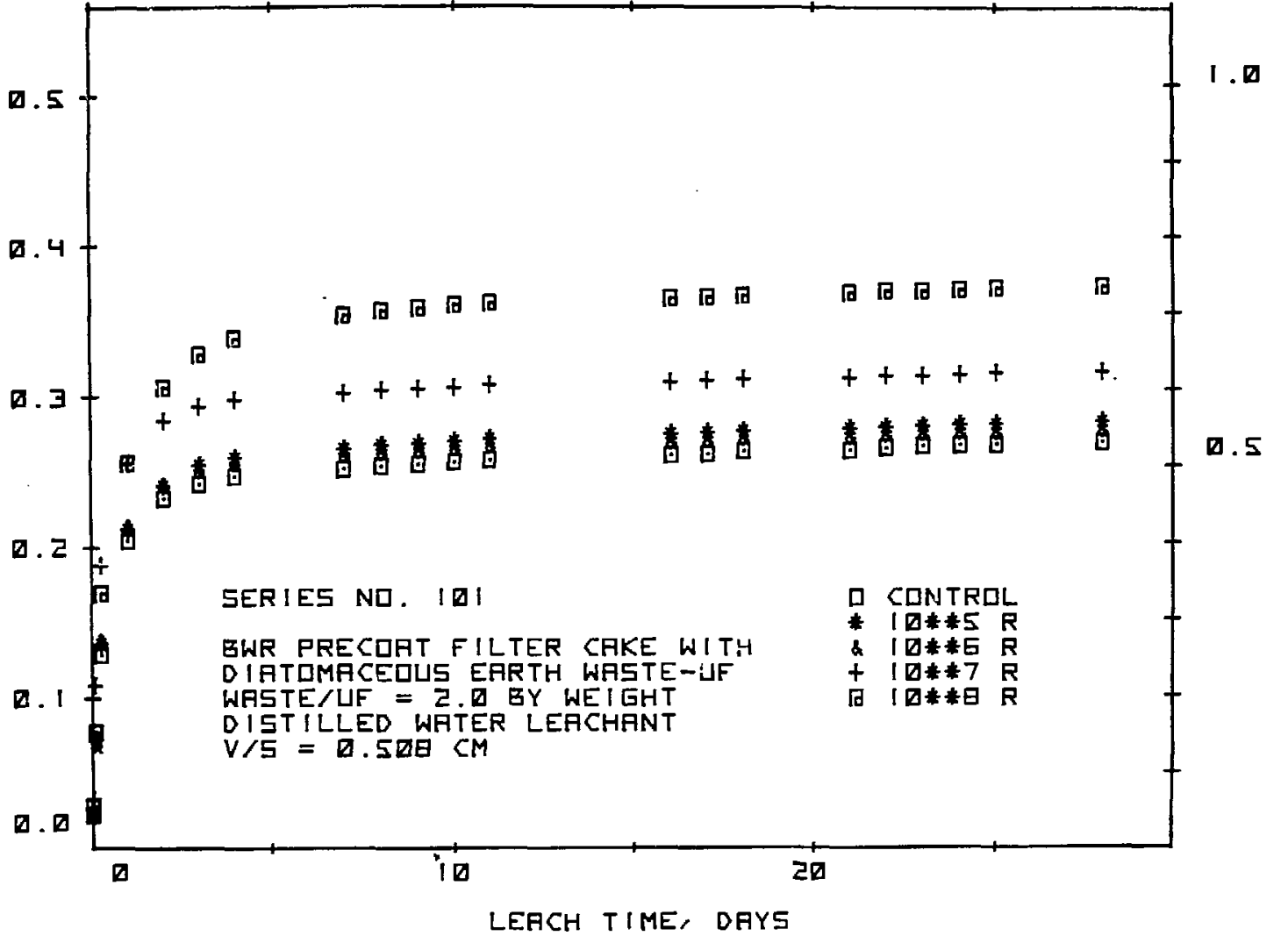

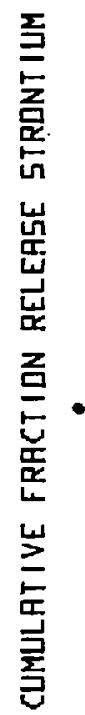

Figure 6.6. The effect of varying doses of ${ }^{60}$ Co irradiation on the leachability of ${ }^{85} \mathrm{Sr}$.

COBALT-6O RADIOLYSIS OF UREA-FORMALDEHYDE

(I PART RESIN:2 PARTS WATER, BY VOLUME)

DOSE RATE $=4.84 \times 10^{6}$ RAD $/$ HR

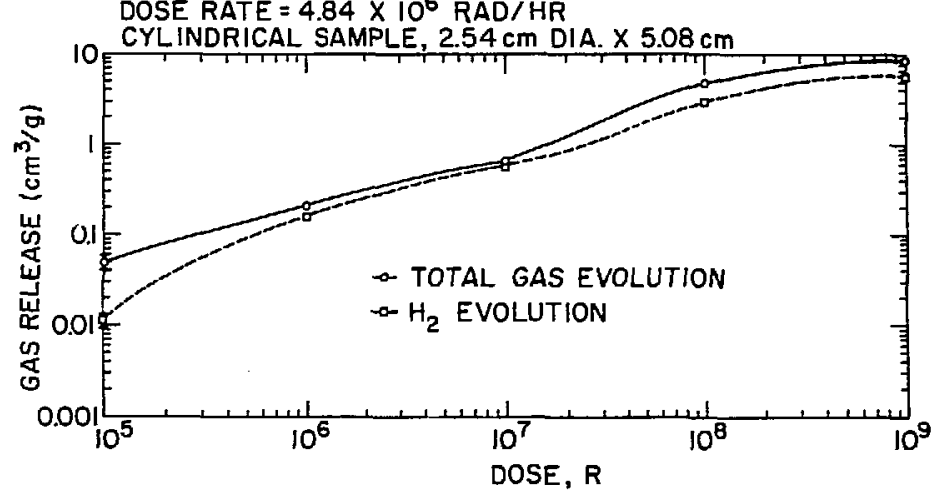

Figure 6.7. Radiolytic gas evolved from ${ }^{60}$ Co irradiation of a urea-formaldehyde waste form. 
waste type and loading. Particle size distributions for particulate generated under impact have been reported for urea-formaldehyde waste forms [6.8]

\subsubsection{Radiation Stability}

Doses of $3 \times 10^{6}$ rads can cause mild to moderate radiation damage, while doses of $2 \times 10^{7} \mathrm{rads}$ can cause moderate to severe damage [6.6]. Inclusion of cellulose fillers in urea-formaldehyde waste forms increases the susceptibility of the material to radiation damage. Excessive exposure to ganma radiation will cause the form to become brittle, blister, swell and crumble [6.2]. Radiolytic evolution of gas can occur in urea-formaldehyde and is dependent on the amount and type of waste solidified. Figure 6.7 shows the volume of gas generated as a function of radiation exposure [6.4]

\subsubsection{Thermal Stability}

Upon exposure to flame, urea-formaldehyde is a self-extinguishing material. The surface of the solid contains large proportions of water. When exposed to fire the water evaporates and the surface chars forming an insulating layer which produces carbon dioxide as the UF begins to decompose. Weight losses, upon burning, of less than $10 \%$ were attributed principally to loss of water $[6.4]$.

Thermogravimetric analysis has demonstrated that rapid weight loss occurs first between $100^{\circ} \mathrm{C}$ and $150^{\circ} \mathrm{C}$ due to evaporation of water, and again at $290^{\circ} \mathrm{C}$ when the resin begins to decompose [6.4]. Water from urea-formaldehyde waste forms is also released by drying in air. Figure 6.8 shows the percentage of initial weight as a function of time for urea-formaldehyde samples exposed to air at $20^{\circ} \mathrm{C}$ and $50 \%$ relative humidity. These specimens were cylinders, one inch in diameter and two inches in length $(\mathrm{V} / \mathrm{s}=0.51 \mathrm{~cm})$. During such drying, the waste form loses weight, decreases in density, becomes more brittle, and also has lower compressive strength. 


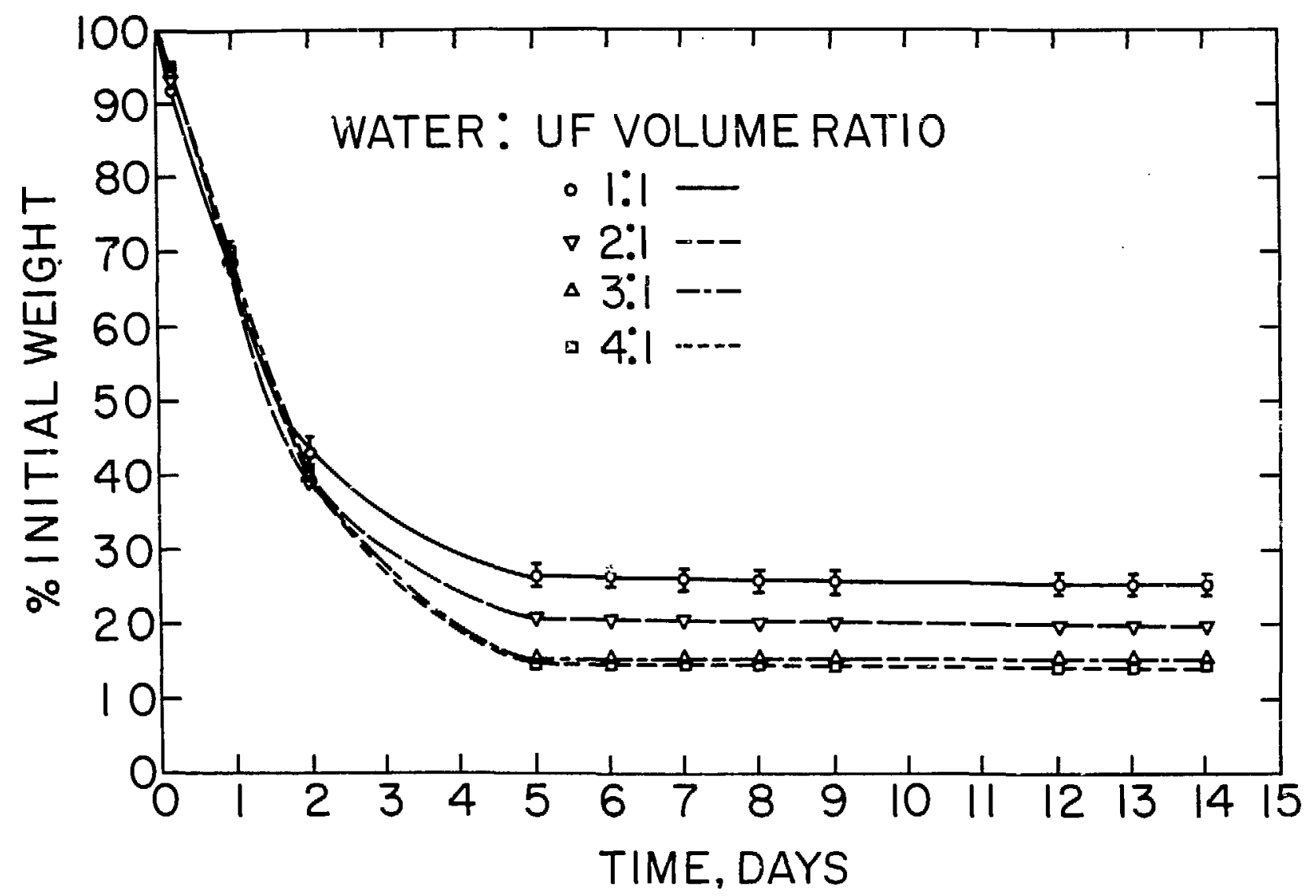

Figure 6.8. Percentage of initial weight plotted against time for UF samples exposed to air.

\subsection{Advantagis and Disadvantages}

Table 6.2 presents the advantages and disadvantages associated with the solidification of waste with urea-formaldehyde. The major disadvantage to use of this material is the free-standing water which often occurs. This problem is leading to the disuse of urea-formaldehyde as a low-level waste form. 
Table 6.2

Advantages and Disadvantages of Low-Levei Waste Matrices

Urea-Formal dehyde

1. Material and technology well known

2. Additives may be used to fix certain nuclides or increase strength

3. Simple equipment requirements

4. Material cost is moderate

5. Ease of working with liquid componants

6. Relatively high waste loading
1. Occurrence of fres standing water

2. Free standing water is acidic-can co. rode container

3. Incompatable with some wastes, e.g.: organic liquids, detergents

4. Limited shelf-life

5. Mixing must be thorough in order to assure no differential settling

6. Vapor is a concern during storage and processing

7. Water loss due to evaporation

8. Relatively high leachability

9. Relatively low rompressive strength 
REFERENCES FOR SECRION 6

[6.1] Alternatives for Managing Wastes from Reactors and Post-Fission Operations in the IWR Fuel cvcle, Vol. 2, ERDA-76-43, U.S. Energy Research and Development Administration, Washington, DC., 1976.

[6.2] Colambo, P. and Neilson, R. M., Jr., Critical Review of the Property of Solidified Radioactive Waste Packages Generated by Nuclear Power Reactors, BNL-NUREG-50591, Brookhaven National Laboratory, Upton, NY, 1976.

[6.3] Neilson, R. M., Jr. and Colombo, P., solidification of I,iquid Cencentrate and Solid Waste Generated as By-Eroducts of the Jiquid Radwaste Treatment Systems in Light Water Reactors, BNL-NUREG-22839, Brookhaven National Laboratory, Upton, NY, 1977.

[6.4] Colombo, P. and Neilson, R. M. . Jr., Properties of Radioactive Wastes and Waste Containers - First Topical Report, BNL-NUREG-50957, Brookhaven National Laboratory, Upton, NY, 1979.

[6.5] Holcomb, W. F., A Survey of the Available Methods of solidification for Radioactive Fastes, ORP/TAD-78-2, U.S. Enviromental Frotection Agency, Washington, DC, 1978.

[6.6] Feizollahi, F., Ion-IeveI Radioactive Waste Management, Vo], IV: Badioactive Waste Solidification and Handling Practices, PB 80-105075, U.S. Dept. of Commerce, Washington, DC, 1979.

[6.7] Neilson, R.M., Jr. and Colombo, P, Rroparties of Radioactive Wastes and Waste Containers Progress Report, No. 11, BNL-NUREG-51042, Brookhaven National Laboratory, Upton, NY, 1979.

[6.8] Colombo, P. and Nielson, R.M. Ir., Properties of Radioactive Wastes and Waste Containers, Ouarterly Progress Report, January - March, 1977. BNL-NUREG-50692, Brookhaven National Laboratory, Upton, NY, 1977. 


\section{POLYESTER TYPE POLYMIRR SYSTEMS AS AGENTS FOR LOW-LEVEI WASTE}

\section{SOLIDIFICATION}

polyester type resins have been investigated for low-level waste solidification. One such system is coming into use as a mobile unit at nuclear power plants.

\subsection{Description of Polvester Type Resins}

Polyester resins are thermosecting polymers and are part of a large group of materials that are the products of the condensation reaction between a polyhydric alcohol and a polybasic acid [7.1]. Polyester resins are liquids at room temperatures that, with the proper initiators, accelerators and conditions (e.g., temperature) will polymerize, forming a hard solid. These are thermosetting polymers and cannot again be liquified without destroying the material. Many of the liquid monomers present some handling problens prior to solidification due to vapor and fire hazards. Polyester resins can be made water extensible, that is, they can form an emulsion vith water in the waste (solute) under high shear mixing. After addition of the appropriate catalyst /promoter the solvent (polyester resin) can solidify, physically imobilizing the water in a small closed cell structure within the solidified matrix. Waste solids are physically entrapped in the polymer matrix. Other polyester resins are appropriate only for the solidification of dry solid wastes. Vinyl esters are typically diluted with 40-50 wto styrene in order to reduce the viscosity of the monomer. Aqueous wastes are introduced into water extensible vinyl ester-styrene under high shear mixing in order to form an emulsion with water in the waste. Polymerization is induced at room temperature by use of a catalyst-pramoter addition. The promoter serves to cause the catalyst to decompose at roam temperature and induce polymerization. Benzoyl peroxide 
catalysts alone decompose aná produce free radicals only at elevated temperatures $\left(\sim 50^{\circ} \mathrm{C}\right)$. Some $10 \mathrm{w}^{\prime}$ temperature polymierization catalysts are available but then they tend to be unstable and are more difficult to use than the catalyst/promoter system. Sone wastes may interact with the catalyst or promoter, necessitating increased additions of these materials. Wastes in the pH range of 2.5 to 10.5 can be solidified with the vinyl ester-styrene marketed by Dow Chemical company, although some wastes, such as boric acid, may require pretreatment $[7.1,7.2]$. Vinyl esters are relatively resistant to chemical attack because of the double carbon bonds at each end of the chain [7.1] Crosslinking takes place only at the ends of the molecule, thereby producing a polymer which can elongate under stress $[7,1]$.

Other polyester or polyester-styrene resins do not form an emulsion with water and are unsuitable for the solidification of aqueous wastes. They can however, be used to solidify solid wastes.

\subsection{Additives}

Additives such as those described in Section 3.1 could be incorporated into polyester waste forms to inhibit leaching of radionuclides. More typically, additives are used to precondition waste, for instance by adjusting the $\mathrm{pH}$, before being mixed with the solidification agent.

\subsection{Solidification Processes Using Polyester Resins}

\subsubsection{Vinyl Ester-Styrene (Dow Chemical Company)}

Dow Industrial Services, a division of Dow Chenical Company, Midland, MI, has developed a system to solidify low-level radioactive waste using a vinyl ester-styrene which can form an emulsion with aqueous wastes. This material is the only thermosetting polymer, other than urea-formaldehyde, 
that has been employed in industry. This system has recently (sept., 1980) come into regular industrial use at the Quad-Cities (Cordova, Ill.) power plant where eight $50 \mathrm{ft}^{3}$ liners have been processed. Previous experience consisted of a variety of full-scale demonstration projects at power plants in the USA and Japan and some work at the Three Mile Island cleanup. Systems are currently being installed in other plants.

The waste form containers, either 55 gallon drums or $50 \mathrm{ft}^{3}$ liners, are first filled with a predetermined volume of binder. Each is then conveyed to the filling position where a measured volume of waste, which previously had been blended or pretreated if necessary to suit the process, is added at a predetermined rate to the binder. High shear mixing is performed in the container to form an emulsion of the liquid waste within the binder. Care must be taken to attain the proper waste/binder ratio in order to avoid "breaking" the emulsion. Appropriate catalyst and promoter additions are also made, in a specific sequence, to the binder or to the waste-binder emulsion. . The waste form solidifies at room temperature in about an hour [7.3]. Progress of the solidification process is monitorod at a station where the exothermic heat evolved $\left(60-70^{\circ} \mathrm{C}\right)$ and resistance to penetration are measured by remote probes. The nominal solidification rate is 3 gallons per minute of radioactive waste, filling six 55 gallon drums in an hour. Figure 7.1 is a schematic of the process [7.3]

\subsubsection{Water Extensible Polyester}

A similar method for encapsulation of wastes in a polyester-waste emulsion was developed to the prototype stage at Washington State University 


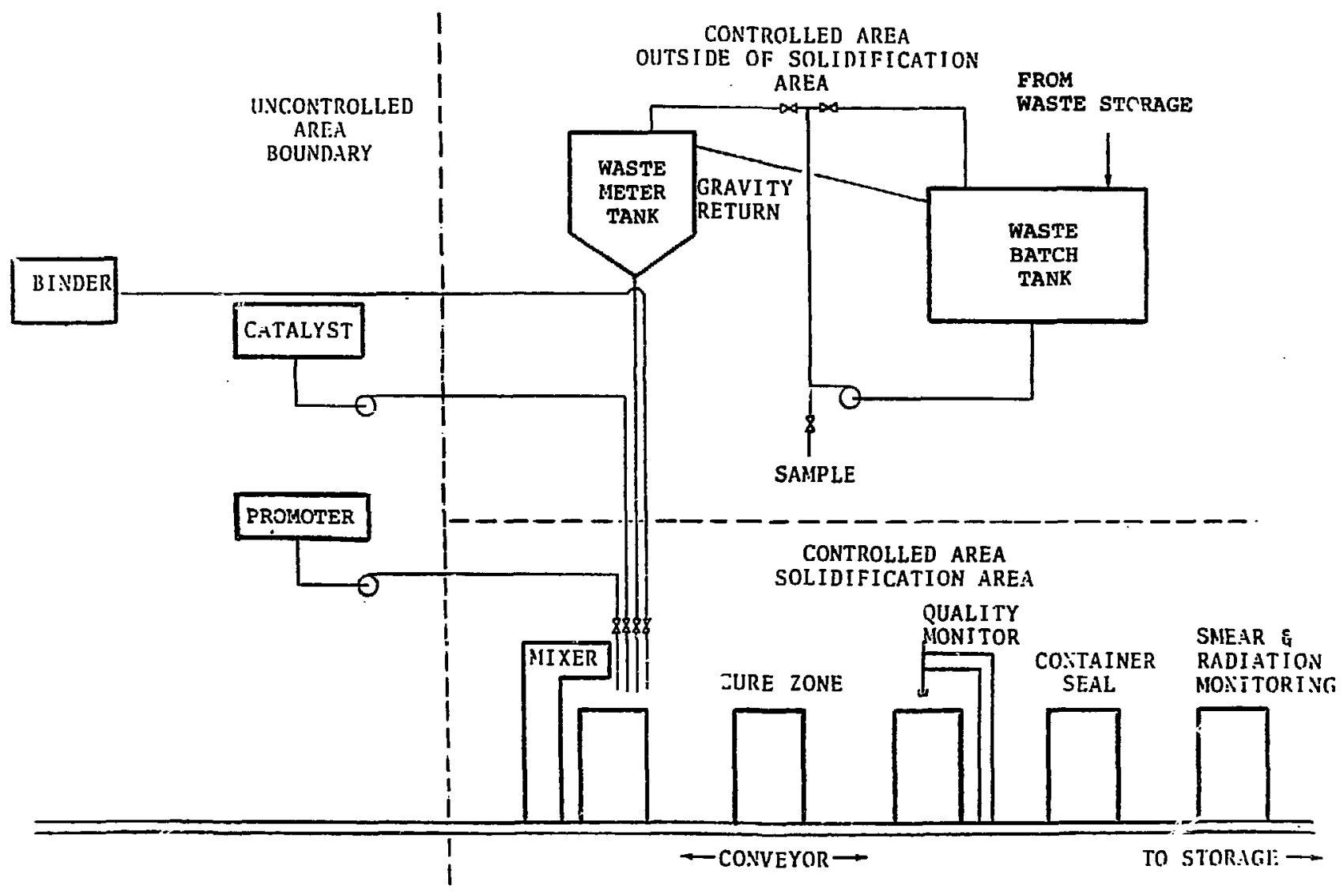

Figure 7.1. A schematic of the Dow process. 
$[7.4,7.5,7.6]$. In essence, this method is similar to the Dow Chemical process and also employs the concept of high shear mixing of waste in a polyester resin in order to produce closed cells containing the waste within a matrix of the polymer. However, an in-line rather than in-container mixer is used. This process also employs a different polyester resin than the Dow process.

\subsubsection{Polymer Concrete}

Another system utilizing polyester type resins is the polymer-concrete (PC) system. Polymer-concrete was developed at Brookhaven National Laboratory as a means of solidifying dry wastes and liquid wastes absorbed on a solid substrate. Polymer concrete is a composite formed by mixing dry waste solids with a monomer and then polymerizing the monomer. The monomer systems typically used are a mixture of $70 \%$ styrene and $30 \%$ divinylbenzene, methylmethacrylate or polyester-styrene. Polymerization is generally achieved through addition of a catalyst but additional polymerization and crosslinking may be provided by heat or irradiation. Between 10 and 50 wto of the total waste form is comprised of the monomer, with 208 being commonly used. Bulk volume increases after addition of the monomer are generally small or negligible and can be produced in two ways. The monomer, catalyst, promoter, additives and the waste can be blended in a mixer and then poured into the waste container. High shear mixing is not required, since the process does not rely on emulsion formation. Simulated Idaho Falls $\mathrm{Al}_{2} \mathrm{O}_{3}$ aná $\mathrm{ZrO}_{2}$ cal.cine wastes were solidified in polymer-concrete using a styrene monomer with 1 wtz benzoyl peroxide as a catalyst, and 2.5 wto divinylbenzene to induce crosslinking between the polymer chains [7.7]. Extensive crosslinking forms a network which renders the polymer hard and inelastic [7.3]. 
Another method of producing polymer-concrete waste forms simply entails filling a waste container with the dry waste and then pouring the monomer-catalyst mixture into the container. This method works best if the dry waste is coarse grained, allowing the fluid to easily flow into the pore spaces. If the waste is very fine grained, the penetration of the fluid through the waste may be poor or an air bell may form inhibiting thorough penetration of the monomer. This problem can be overccme by introducing the fluid, through a fitting, into the container from the bottom. A gravity feed from an elevated tank provides more complete saturation of the waste with the monomer. Vacuum or pressure techniques could also be applied. Little increase in bulk volume results.

\subsection{Waste Form Characteristics}

\subsubsection{Chemical compatibility}

Vinyl ester-styrene waste forms are compatible with most wastes. It is imperative, however, that the waste be of an acceptable $\mathrm{pH}$, otherwise a stable emulsion may not be formed. Other wastes, such as boric acid concentrates, require pretreatment to provide an acceptable waste form. Some wastes may interact with the catalyst and/or promoter and thus require increased catalyst/promoter additions or modification of the order of addition. Waste to binder ratios from 1.5 to 2.0 are typically recommended for various waste types.

Data on the chenical compatibility of polymer concrete are limited. The chemical compatibility of wastes for the PC system should be similar to that for water-emulsion systems. However, solidification in PC does require that the waste be either dry or that it bear water as a stable solid containing absorbed water. This process cannot acconmodate significant quantities of unbound water. 


\subsubsection{Leachability}

Leaching studies have been carried out by the Dow Chemical Company and by Brookhaven National Laboratory for vinyl ester-styrene waste forms. The latter samples were prepared to Dow Chemical specifications, and as such should simulate products of their system. Figure 7.2 presents the leachability for ${ }^{60} \mathrm{Co}$ and ${ }^{137} \mathrm{Cs}$. As witil most other waste forms, the leachability varies from nuclide to nuclide and with different types of waste [7.8]. The effect of prior heating at $538^{\circ} \mathrm{C}$ for ten minutes on the leachability of vinylester styrene is shown in Figure 7.3 [7.9]. Heating resulted in an acceleration of initial leaching of ${ }^{137} \mathrm{Cs}$; however, the overall cumulative fraction leached began to approach that of the control after 90 days [7.9].

Cumulative leachability of sodium from the Washington State University polyester waste forms has been reported to be approximately $0.2 z$ (at 50 wtz loading) after 6 months. At loadings of 70 wto the cumulative leaching was about $28[7.4]$.

Experiments have been performed at BNL to observe the leachability of $\mathrm{NaNO}_{3}$ and cesium from polymer-concrete and to determine the effect of additives on these waste forms. The results are shown in Fig. 7.4 for $\mathrm{NaNO}_{3}$ leaching and in Figure 7.5 for cesium. These specimens were $2.5 \mathrm{~cm}$ diameter $\mathrm{x}$ $5.1 \mathrm{~cm}$ long. The polyester-styrene (PS) and the polymethyl methacrylate (PMMA) waste forms exhibited fraction releases of about 0.20 and $0.24 \mathrm{NaNO}_{3}$, respectively, achieving an equilibrium leach rate very rapidly. The difference in leachability between the two waste forms is believed to have been the product of the packing of $\mathrm{NaNO}_{3}$ crystals during preparation of the samples. This high initial release was due to dissolution of $\mathrm{NaNO}_{3}$ exposed at the surface of the waste form which was not well encapsulated by the resin. Addition 


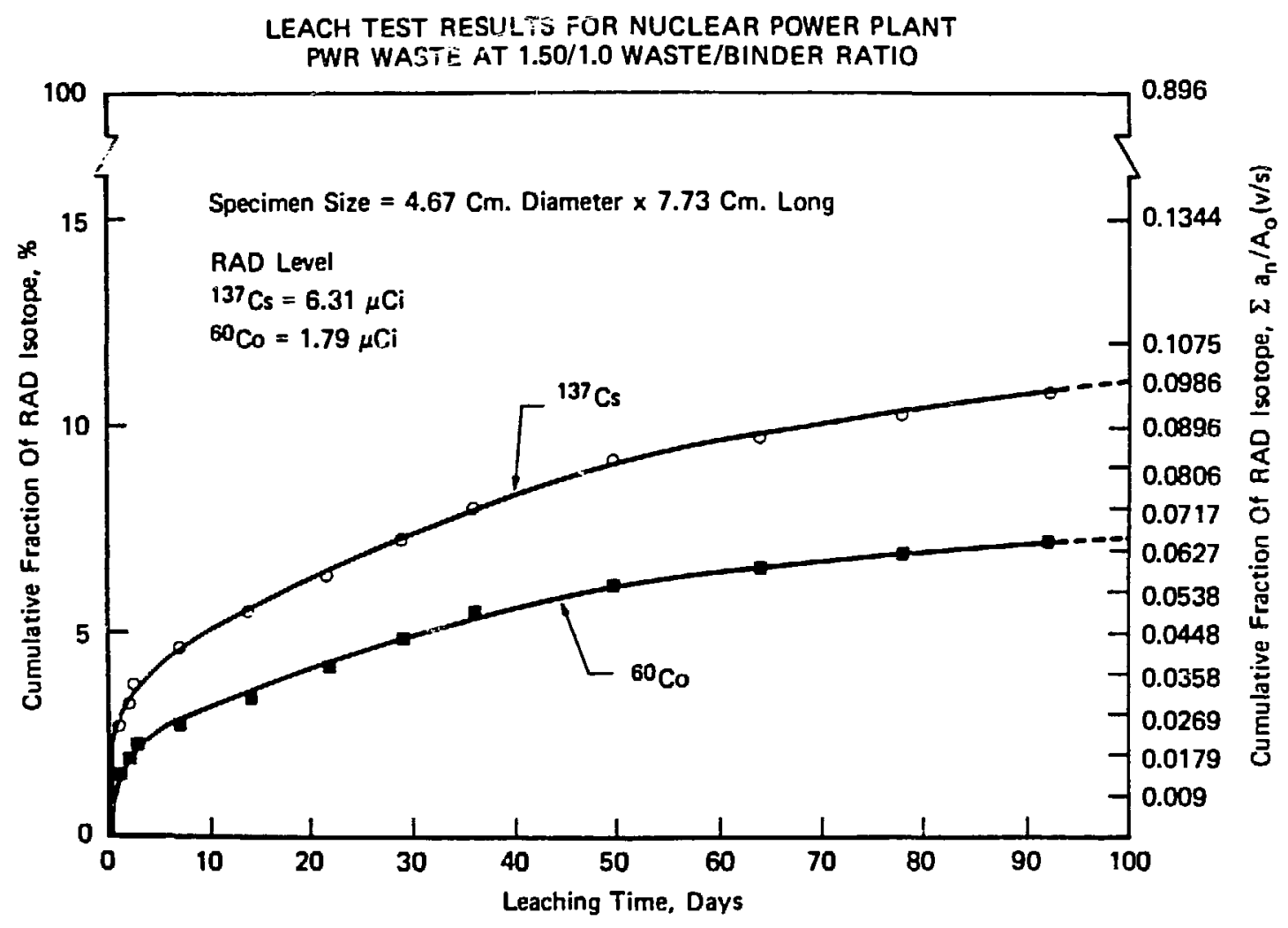

Figure 7.2. Fraction release of ${ }^{137} \mathrm{Cs}$ and ${ }^{60} \mathrm{Co}$ from evaporator sludge solidified in vinyl ester-styrene. 


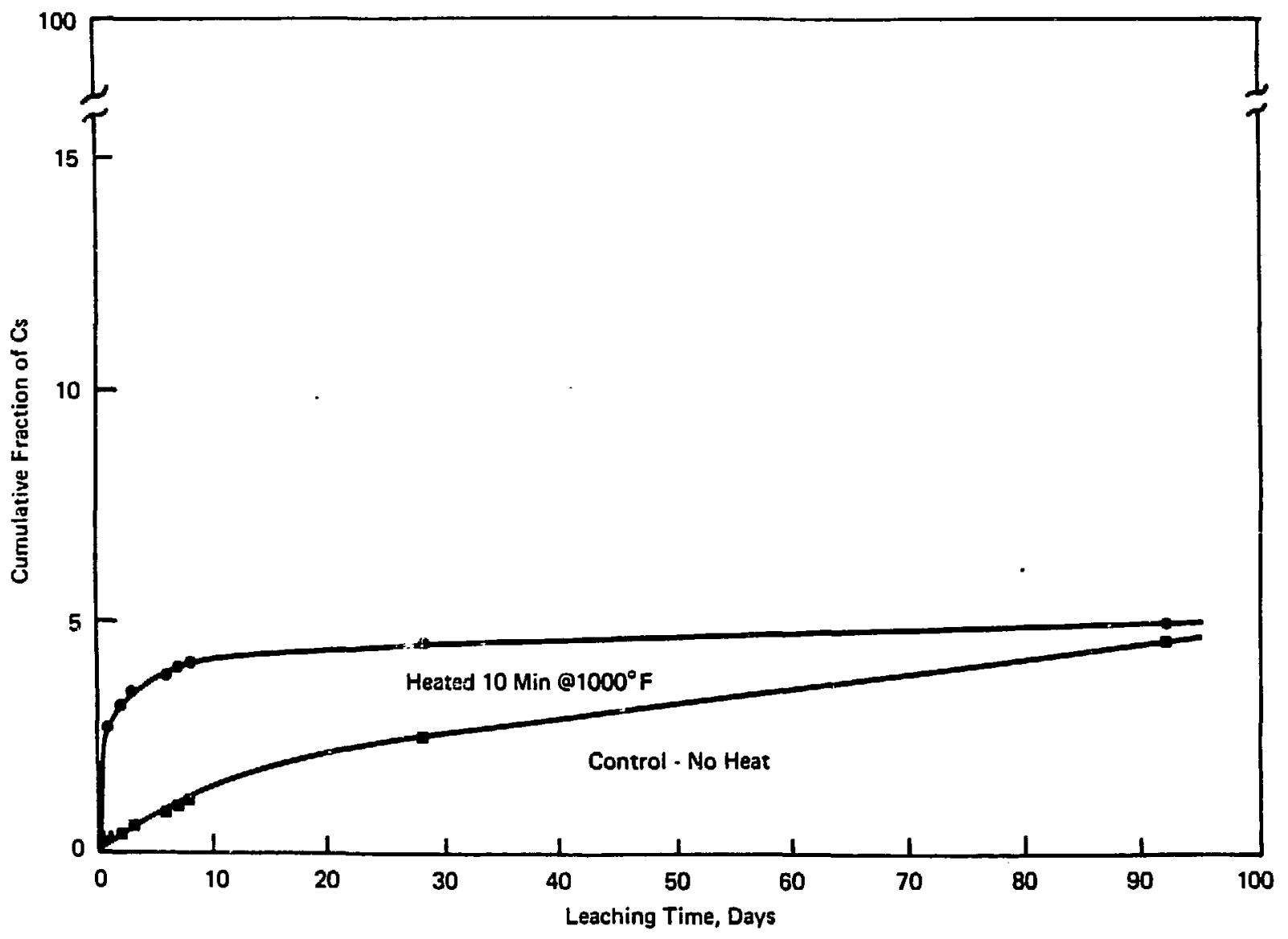

Figure 7.3. Cumulative fraction release of $C_{s}$ showing the effect of heating the waste $f\left(i m\right.$ to $1000^{\circ} \mathrm{F}\left(538^{\circ} \mathrm{C}\right)$ for 10 minutes. 


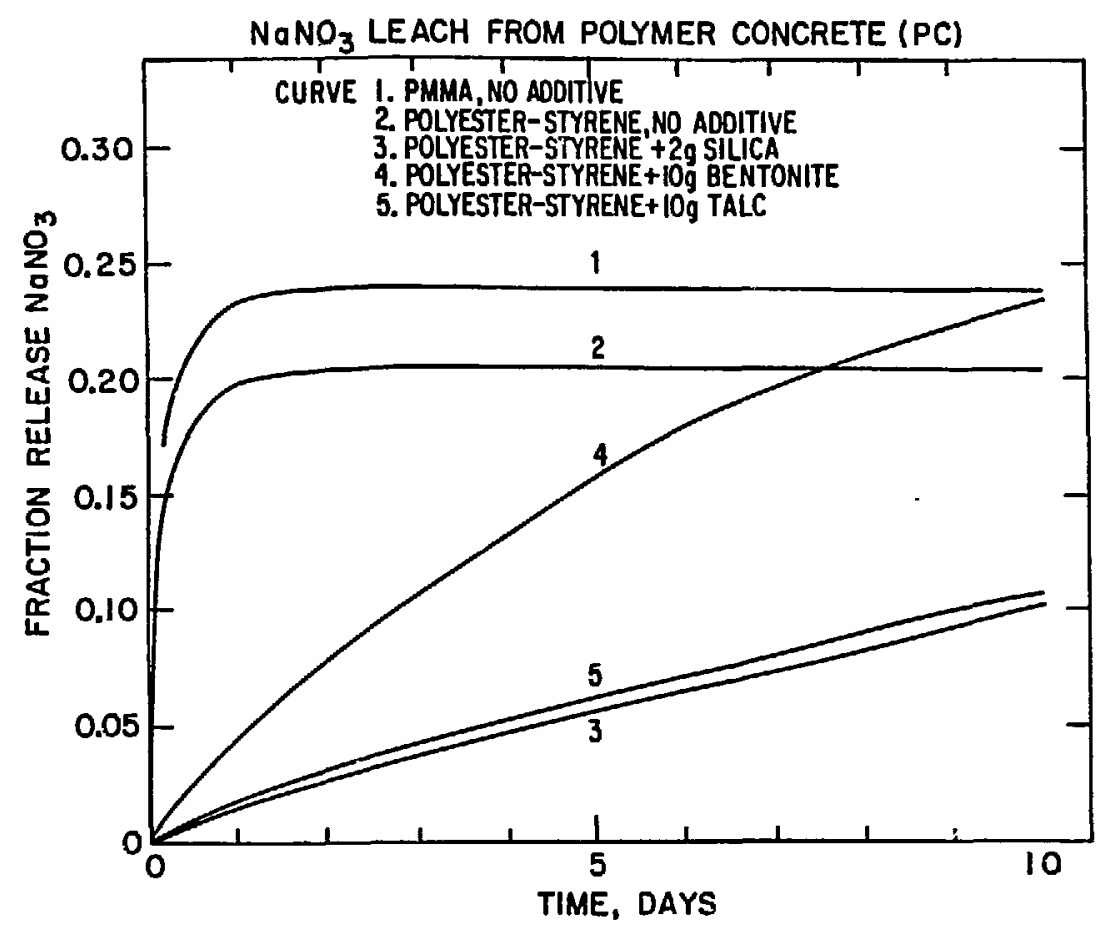

Figure 7.4. Fraction release of $\mathrm{NaN}_{3}$ from a polymer coricrete containing various additives.

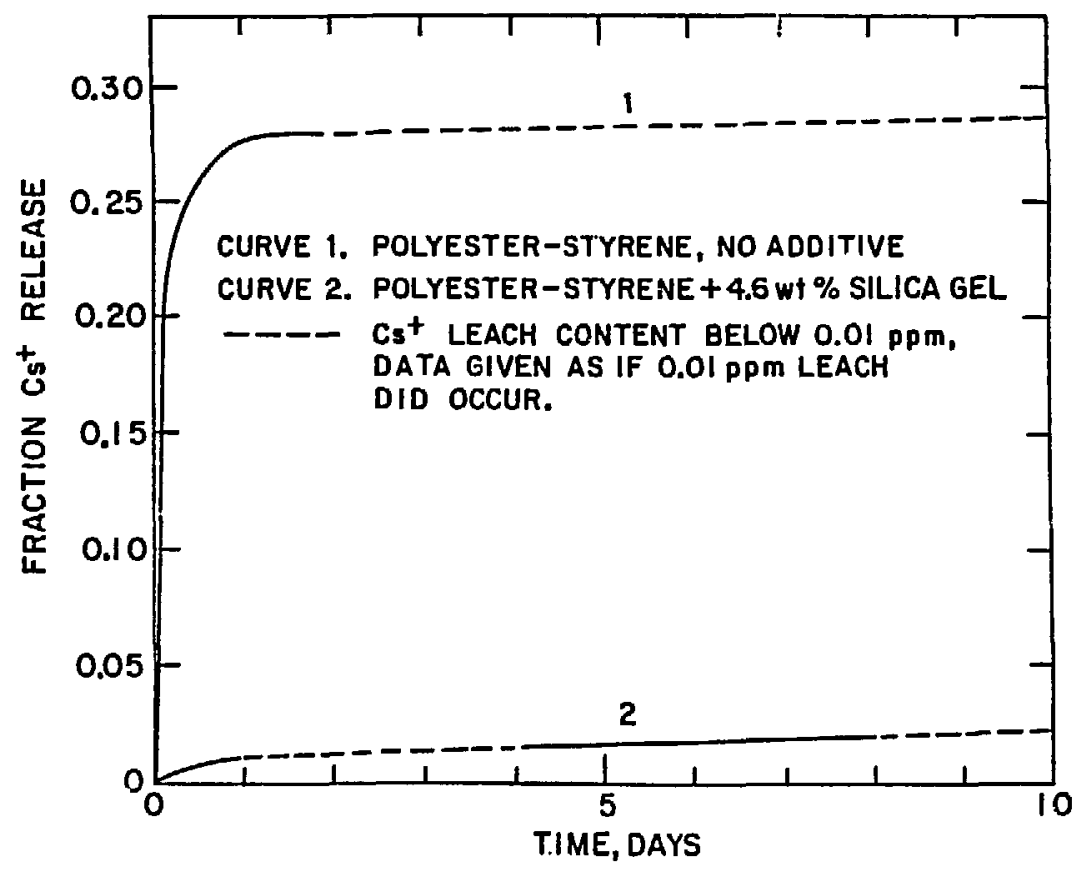

Figure 7.5. Fraction release of Cs from a polymer concrete with and without silica gel added to retain cesium. 
of ion sorbers (silica, talc and bentonite) to polyester-styrene significantly decreased the initial rate of leaching (talc and silica samples especially). These samples had not yet equilibrated after 10 days. They reached a fraction release of 0.10 in that time. The additives however are believed, in the case of $\mathrm{NaNO}_{3}$, to act as absorbents of the water, thus slowing the initial leachability but perhaps not affecting the long term leaching. Coating the polymerconcrete composite with polyester-styrene resin (0.15-0.25 $\mathrm{mm}$ thick) was found to reduce the fraction release to non-detectable levels.

Cesium release was also measured. The fraction release for this ion in PMLA waste forms was 0.13-0.14 over 10 days; in PS it was 0.29; in PS with silica, bentonite or talc adided, the cumulative fraction releases, respective$I y$, were $0.015-0.023,0.0090-0.015$, and $0.072-0.030$. This demonstrates significant retention of cesium. These samples had reached equilibrium [7.10] • Polymer concrete was also tested for leachibility of $\mathrm{NaNO}_{3}$ fram $\mathrm{Al}_{2} \mathrm{O}_{3}$ calcine. The fraction release observed was $0.03-0.04$ for non-irradiated samples, and about 0.02 for samples irradiated to $2.5 \times 10^{9}$ rads. In this case, the calcine absorbed $38 \%$ of the styrene monomer; the remaining monomer filled the pore spaces between calcine particles, producing a waste form with a particularly low leachability [7.10].

\subsubsection{Mechanical Strength}

The compressive strength of vinyl ester-styrene specimens with varying water to binder weight ratios was measured at Brookhaven National Laboratory [7.7]. The material failed in a brittle manner. Droplets of water were observed on the shattered pieces, apparently squeezed fran the waste form. The compressive strengths for waste forms having $1.0,1.5$ and 1.9 water/binder ratios by weight were 2900,2100 and 1300 psi respectively. 
Compressive strength tests were made with polymer concrete (polystyrene-divinylbenzene) waste forms containing $\mathrm{NaNO}_{3}$ waste [7.1i]. A rapid loss of strength occurred about $121^{\circ} \mathrm{C}$. Upon substitution of silica sand for the $\mathrm{NaNO}_{3}$ the loss of strength was significantly less pronounced.

\subsubsection{Radiation Stability}

Experiments carried out by the Dow Chemical Company showed that their vinyl ester-styrene binder is relatively stable with regard to radiation effects. Figure 7.6 illustrates the cumulative iraction release of ${ }^{137} \mathrm{Cs}$ plotted as a function of time for a variety of radiation exposures. Low exposures have no significant effect on leachability [7.12]. Exposures of $4 \mathrm{x}$ $10^{8}$ and $6 \times 10^{8}$ rads as much as tripled the leachability; however, this was still below a cumulative relase of 58 in 100 days [7.12]. Similar doses had no effect on the leachability of ${ }^{60} \mathrm{Co}[7.12]$.

The effect of irradiation on the compressive strength of the Dow binder was also studied (Figure 7.7). In ger sal, there was an increase in both yield strength and maximum strength up to doses of about $2 \times 10^{6}$ rads. The yield strength remains the same as the maximim strength is reduced and meets the yield strength at $1.8 \times 10^{7}$ rads. At this point, the compressive strength of all vinyl ester-styrene waste forms began to drop. The initial increase in strength is the result of increased cross-linking of polymer chains induced by irradiation.

Polymer concrete specimens made with polystyrene containing 108 or $30 \%$ DVB were irradiated at $1.2 \times 10^{7}$ rads $/ \mathrm{hr}$ with ${ }^{60} \mathrm{Co}$. This irradiation caused heating of the center of the waste form to $155^{\circ} \mathrm{C}$. These 3 inch diameter by 6 inch long cylinders received total does of $10^{9}$ rads. Extensive cracking occurred, presumably due to gas generation. This effect may be a consequence of the high radiation dose rate and hence of no concern for actual 
${ }^{137}$ Cs Leach Test Results for Irradiated PWR Waste $\cdot 1.65 / 1.0$ Waste/Binder Ratio

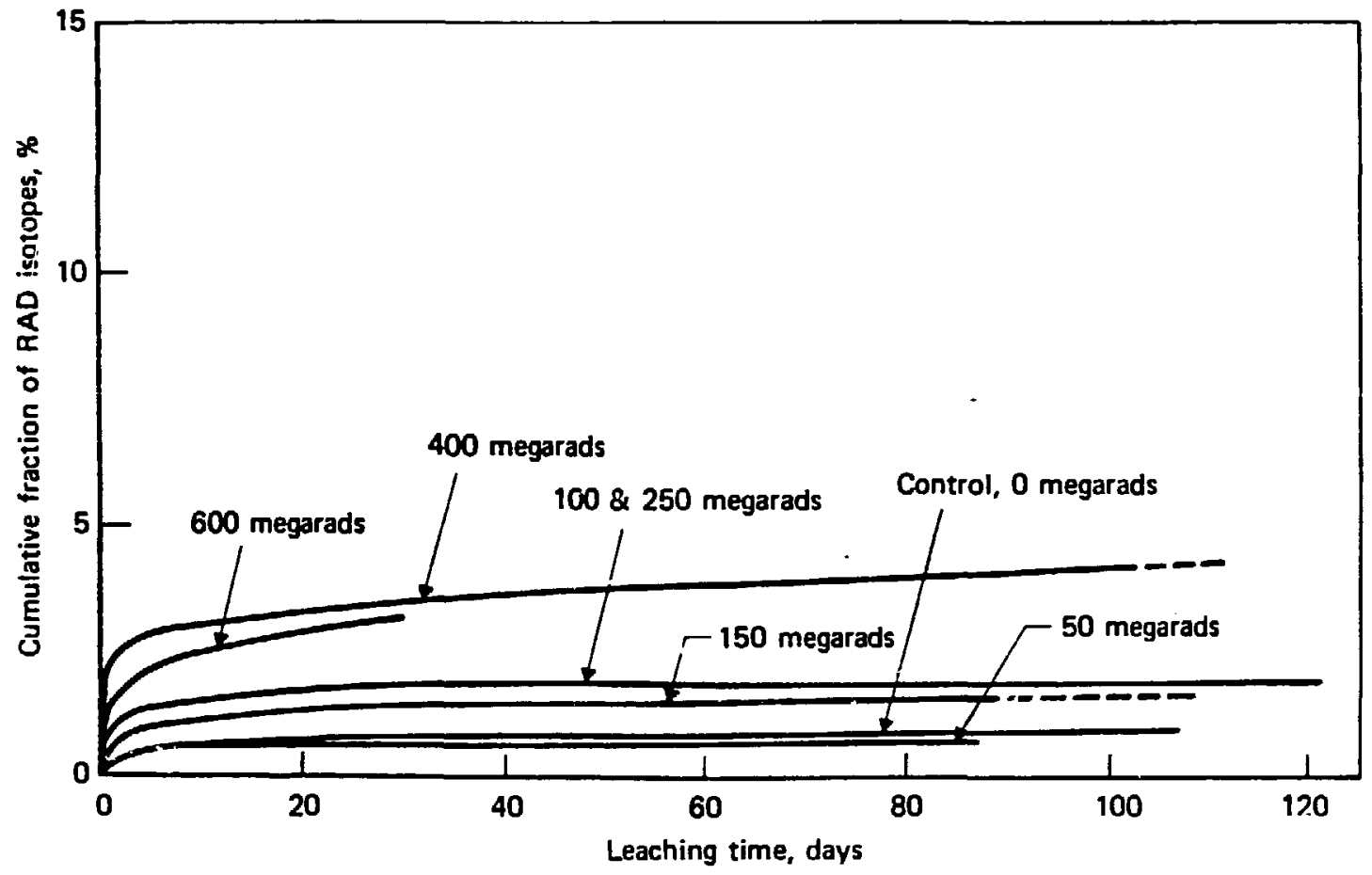

Figure 7.6. Fraction release as a function of irradiation dose. 
EFFECT OF RADIATION ON SOLIDIFIED PWR WASTE

- 1.65़/1.0 WASTE/BINDER RATIO

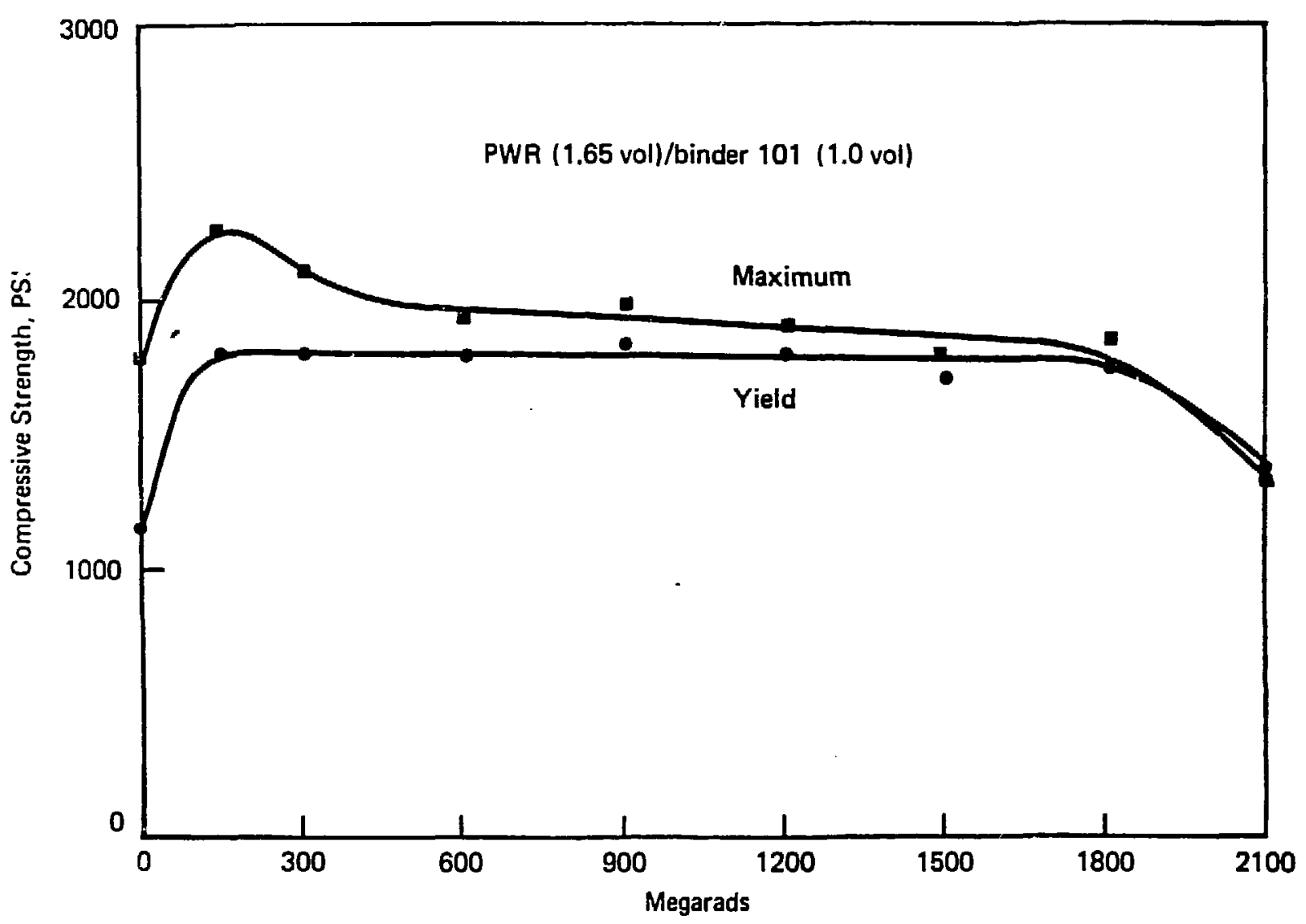

Figure 7.7. Compressive strength as a function of irradiation dose. 
wastes. At high dose rates, the radiolytic production of hydrogen may exceed the rate at which it diffuses through the waste form. At more representative (lower) dose rates, such sample pressurization should not occur. An experiment designed to simulate the gamma heating effect of the irradiation experiment produced only slight discoloration of the samples upon heating at $150^{\circ} \mathrm{C}$ $[7.13]$.

\subsubsection{Themal Effects}

Vinyl ester-styrene waste forms, upon exposure to burning fuel oil, will char and lose weight. They will not, however, sustain combustion [7.13]. Weight loss occurs due to evaporation of contained water and some polymer decomposition at the surface of the waste form. This water loss can occur at low temperatures as well, although at a much reduced rate.

Experiments have demonstrated that significant quantities of water are evaporated from solidified Dow material in ambient air. Figure 7.8 shows sample weight as a function of time for various water to binder ratios. These specimens were disks, $4.68 \mathrm{~cm}$ diameter and $1.20 \mathrm{~cm}$ thick $(\mathrm{V} / \mathrm{s}=0.40 \mathrm{~cm})$. Not surprisingly, the sample with the greatest water to binder ratio demonstrates the greatest weight loss; about 408 after 70 days [7.7]. This weight loss is much slower than that observed for urea-formaldehyde.

\subsection{Advantages and Disadvantages}

Tables 7.1 and 7.2 present the advantages and disadvantages of polyester type polymers for the solidification of low-level waste. Table 7.1 is for the Dow process, while Table 7.2 considers polymer-concrete. Actual operating experience with the Dow process is somewhat limited. Polymer concrete has been made only on a laboratory scale in this country. Both have the advantages of the low leachability and high strength. 


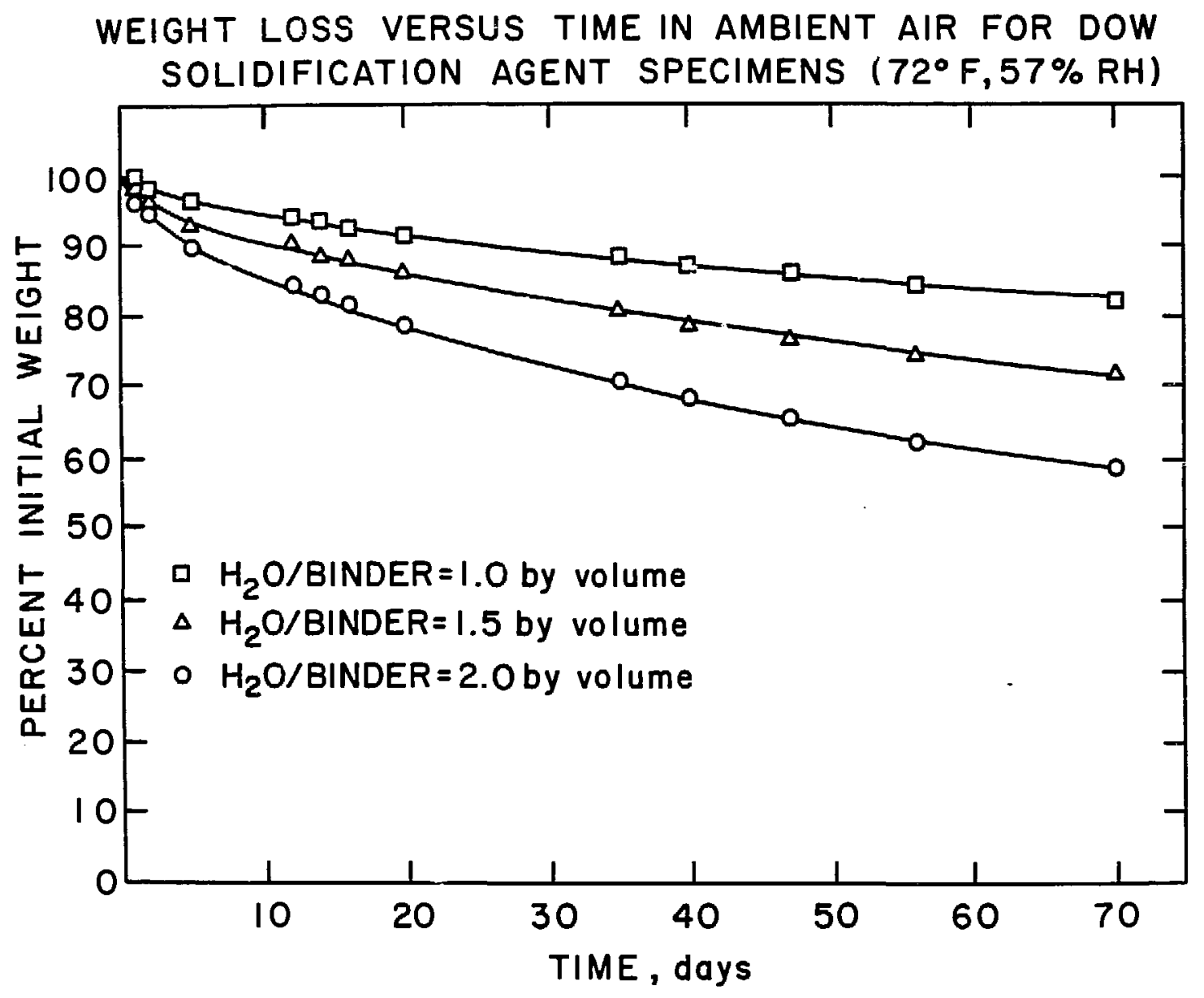

Figure 7.8. Sample weight as a function of time for three samples at various water to binder ratios. 
Table 7.1

Advantages and Disadvantages of Vinyl Ester Sytrene

Dow Process Solidification

1. Adaptable to many wastes-both

1. Limited binder shelf-life solid and liquid

2. No free-standing water

2. Hazards associated with the monomer, catalyst and promotor handling

3. Relatively low leachability

3. Some wastes may interact chemically and prevent/affect polymerization

4. High compressive and impact

4. Relatively expensive materials strength

5. Good radiation stability

5. Mixing method important

6. Ease of working with liquid components

7. In-container mixing available

8. Available in mobile systems 
Table $\mathbf{7 . 2}$

Advantages and Disadvantages of Polymer Concrete Solidification

Advantages

1. High waste loading with negligible volume increase

2. Low leachability

3. High compressive and impact strength

4. No free standing water

5. Relatively insensitive to chemical nature of waste

6. Simple process for combining waste and binder
Disadvantages

1. Applicable only to dry wastes

2. Limited binder shelf-life

3. Hazards associated with monomer handling

4. Relatively expensive materials

5. Some wastes may interact chemically and prevent/affect polymerization

6. Not commercialized to full-scale use 
[7.1] Miles, D. C. and Briston, J. H., Polymer Technology, Chemical Publishing Co., New York, N. Y., 1979.

[7.2] Feizollahi, F., Radioactive Waste Solidification and Handling Practices, Report D., NUS-3245NUS, NUS Corporation, Palo Alto, CA, 1979.

[7.3] Dow System Description, Dow Industrial Services, Dow Chemical Company, Midland, Michigan.

[7.4] Subramanian, R. V., Wu, Wen-Pao, Mahalingam, R. and Juloori, M., Rolyester Encapsulation of Hazardous Industrial Wastes, paper presented at the National Conference on Treatment and Disposal of Industrial Waste Waters and Residues, Houston, Texas, April 26-28, 1977.

[7.5] Mahalingam, R., Juloori, M., Subramanian, R. V. and Wu, Wen-Pao, Pilot Plant Studies on the polyester Encapsulation Process for Hazardous Wastes, ibid.

[7.6] Subramanian, R. V. and Mahalingam, R., Immobilization of Hazardous Residuals by Encapsulation, Annual letter technical report, Washington State University, 1976.

[7.7] Colombo, P. and Neilson, R. M., Jr., Properties of Radioactive Wastes an Waste Containers - First Topical Report, Brookhaven National Laboratory, Upton, NY, 1979.

[7.8] Filter, H. E. and Robertson, $K_{.}$, The Dow System for Solidification of Low-Level Radioactive Wastes from Nuclear Power Plants, Dow Chemical Company, Midland, Michigan 1977.

[7.9] Filter, H. E., Vinyl Ester Solidification of Low-Level Radioactive Waste Dow Chemical Company, Midland, Michigan, 1979.

[7.10] Colombo, P. Steinburg, M. and Manowitz, B., Development of Durable LongTerm Radioactive Waste Composite Materials, Progress Report \#8, BNL19390, Brookhaven National Laboratory, Upton, NY, 1974.

[7.11] Manowitz, B., Steinburg, M. and Colombo, P., Development of Durable Long-Term Radioactive Waste Composite Materials, Progress Report \#2, Brookhaven National Laboratory, Upton, NY, 1973.

[7.12] Filter, H. E., The Dow System for Solidification of Low-Level Radioactive Waste from Nuclear Power Plants, Dow Chemical Company, Midland, Michigan, 1978.

[7.13] Colombo, P. and Neilson, R. M., Jr.,Properties of Radioactive Wastes and Waste Containers- Progress Report No. 10, July-Septenber 1978, BNLNUREG-51026, Brookhaven National Laboratory, Upton, NY, 1973. 


\section{EPOXY AS AN AGENT FOR LOW-LEVEL WASTE SOLIDIFICATION}

United Technologjes Corporation is developing a volume reduction/solidification process that utilizes epoxy resin as the waste form binder. Solidification in epoxy is one step of this integrated volume reduction and solidification process called the inert carrier process. This process also uses epoxy resin to remove waste solids from an inert silicone carrier. This system is discussed in the context of the process in which it is used, although viewed only in the solidification aspect, the resultant waste form is similar to the polymer-concretes described in a previous section.

\subsection{Description of the Inert Carrier Process}

The Inert Carrier Rachwaste Process (ICRP) utilizes an inactive liquid silicone which is maintainea at $150^{\circ} \mathrm{C}$ in the evaporator. As liquid radioactive waste is added to the heated silicone, the high turbulence and temperature of the fluid causes the water to evaporate instantly. The waste solids residue remains as suspended solids in the silicone carrier. With the addition of an immiscible epoxy monomer, the particulates are removed from the silicone carrier. The epoxy monomer-waste solids mixture then falls to the bottom of a separation column and is drawn off. A catalyst is added through a static mixer to induce polymerization of the epoxy monomer and the mixture is deposited into the waste container. The waste form cures in approximately 3 hours. There is no carryover of waste into the carrier which is reused, nor is there any accumulation of epoxy within the system. Figure 8.1 is a schematic of the ICRP System [8.1]. 


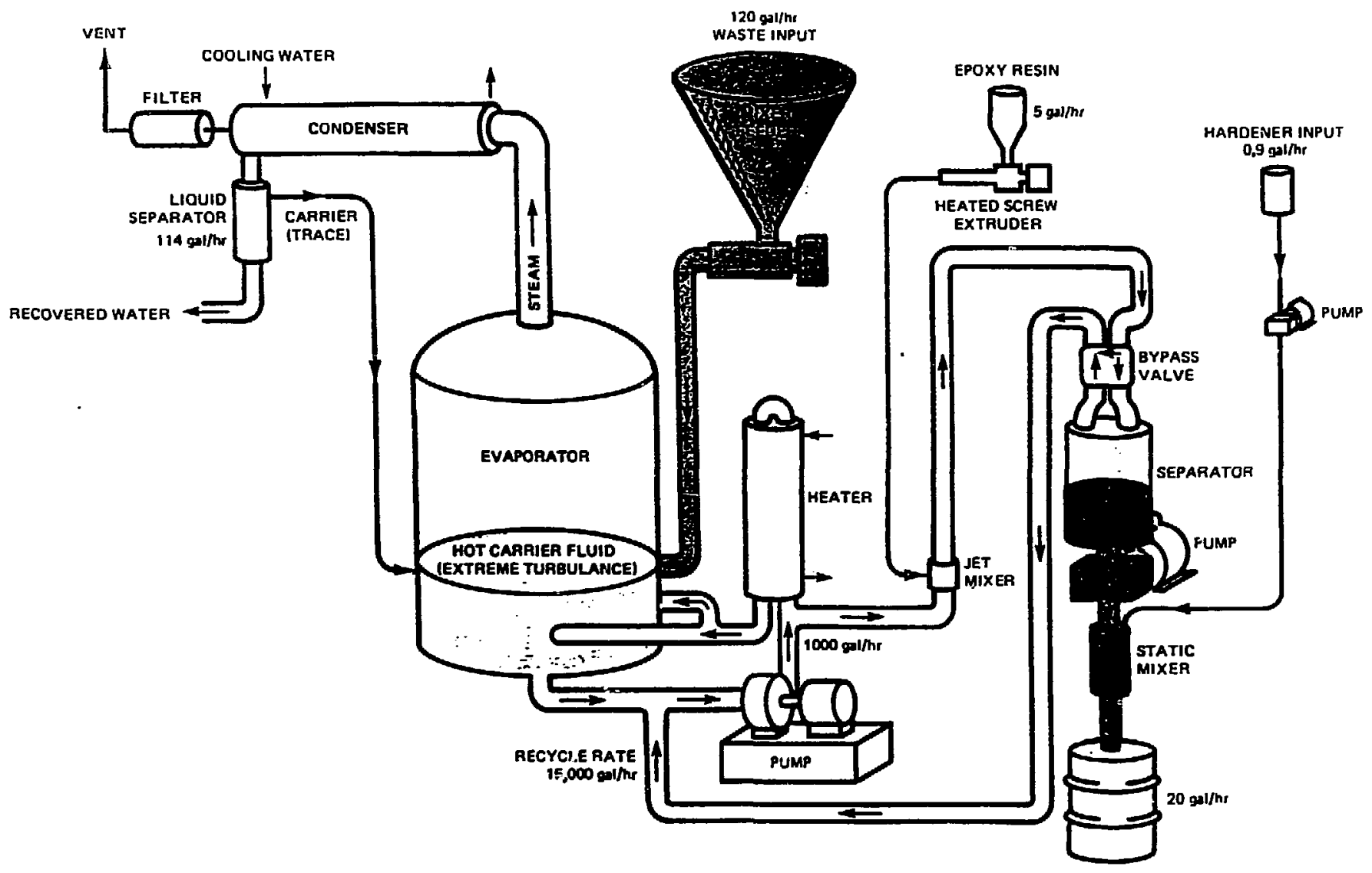

Figure 8.1. Schematic of the inert carrier process [8.1]. 


\subsection{Waste Form Characteristics}

There is little available data describing the characteristics of the waste form produced by this process. Tests run by United Technologies show leachabilities for waste forms containing $70 \mathrm{wtz}$ dry $\mathrm{NaSO}_{4}$ in epoxy resin are less than 18 over a period of 7 days [8.1]. Tensile strengths of 3100 to 4200 psi were measured for similar waste forms. Upon exposure to a flame for 3 minutes, the material smoldered and then self-extinguished within one minute.

\subsection{Advantages and Disadvantages}

The principal advantages of the ICRP is the volume reduction for liquid wastes which is an integral part of the solidification system. A disadvantage of the process is its use of elevated temperatures.

REFERENCES FOR SECTION 8

[8.1] United Technologies Chemical Systems, Inert Carrier Radwaste Process for the Volume Reduction and Solidification of Radioactive Waste, Chenical Systems Divisions, United Technologies, Sunnyvale, CA. 1980. 


\section{MINERALIZATION PROCESSES FOR LOW-LEVEL WASTE SOLIDIFICATION}

A variety of mineralization processes have been developed, which fix radionuclides within a crystal lattice. These processes are generally not in use commercially, although silica polymerization of bulk industrial wastes has been developed commercially. While there is, in some cases, a great deal of literature involving the mineralogy and geochemistry of these materials, there is relatively little information specifically addressing their use for radioactive waste disposal. Most considerations for these processes are for highlevel and industrial chemical wastes, but in many cases they could be suitable for specific low-level waste streams. The applicability of these processes is highly dependent upon the chemical composition of the waste streams.

\subsection{Description of Waste Bearing Minerals}

There are four principal processes which are considered in this section. Each has, to varying degrees, been experimented with as a solidification agent for radioactive wastes. The reactions in each process result in formation of new minerals. These minerals are, in every case, analogous to naturally occurring minerals although the particular salts within them may be found only in radioactive waste. The materials which enter into these processes are clay minerals and nitrates and/or hydroxides of sodium and aluminum. Aluminosilicate lattices, are formed which can strongly retain waste salts forming feldspathoie minerals such as nepheline, sodalite and cancrinite, depending on the content and proportions of the input materials and waste. 


\subsection{Solidification Using Mineralization Processes}

\subsubsection{Clay Reaction Processes}

Experiments at Atlantic Richfield Hanford Company [9.1] have resulted in three processes which utilize the reactions between clay minerals (calcined and uncalcined bentonite and kaolinite) and certain radioactive wastes (caustic liquors, salt cake or dissolved salt cake). In particular, the reactions involve the sodium nitrate, sodium nitrite, sodium hydroxide and aluminum hydroxide within the waste. The reaction products are feldspathoid minerals, sodium nitrate cancrinite and sodalite which may be represented by $6\left(\mathrm{NaAlSiO}_{4}\right) \cdot x$ salt. $\mathrm{H}_{2} \mathrm{O}$, where $x<2$ and $y$ is small when salts are present. sodium hydroxide is also formed. At low concentrations of $\mathrm{NaCH}$ and $\mathrm{NaNO}_{3}$, the mineral sodalite will form concurrently with cancrinite, both containing a wide range of salts [9.3]. The low temperature reactions were carried out at temperatures between $50^{\circ}$ and $100^{\circ} \mathrm{C}$. Calcined bentonite reacted most rapidly going to completion (at $100^{\circ} \mathrm{C}$ ) in less than an hour [9.1].

The Rich Clay process utilizes a stoichiometric excess of clay mixed with liquid waste, producing a cancrinite, clay and waste salt mixture. The Lean Clay process produces relatively pure, small cancrinite crystals by controlling the ratios of the reactants. A binder must be used to solidify the crystalline product. The Clay Calcination process mixes clay with either solid or liquid waste, first producing cancrinite. This product is then heated to $600^{\circ}-1000^{\circ} \mathrm{C}$ forming nepheline. A flow sheet for these processes is shown as Figure 9.1 [9.1]. It should be noted that none of these processes result in any significant volume reduction and some show as much as a sixfold increase in volume. During the crystallization of cancrinite and sodalite, the salts present, as well as the $\mathrm{NaOH}$ and the zeolitic water, are important 


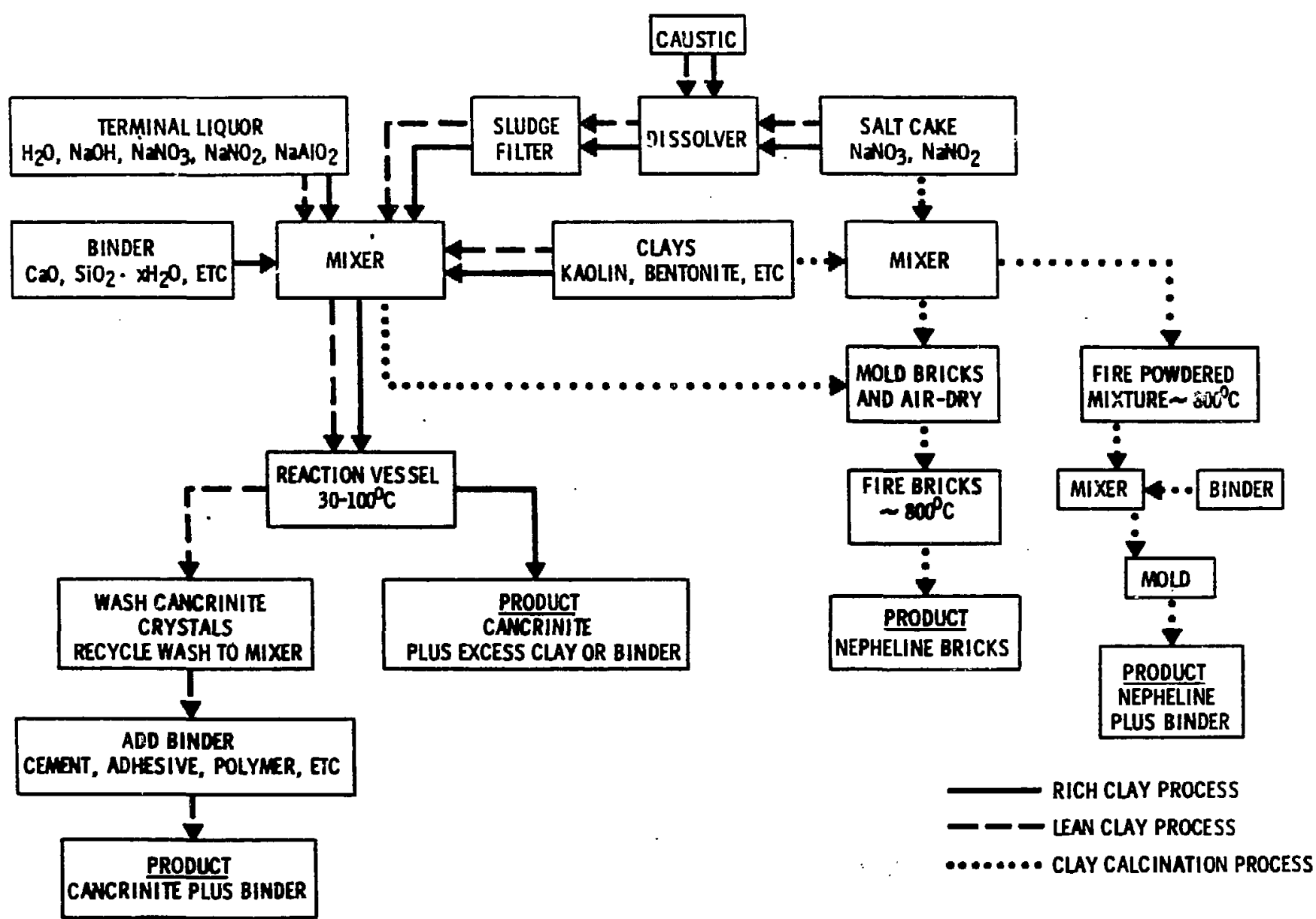

Figure 9.1. Flow charts for three processes: The rich

clay process, the lean clay process and the clay calcination process. 
to the formation and stability of the lattice. Indeed, the anions in the alkaline solution determine which of the two minerals is formed [9.3]. These entrained salts are strongly held within the aluminosilicate lattice and are not released until the crystal lattice is decomposed [9.4].

Another clay reaction process involves the formation of the mineral pollucite. This is a cesium silicate with the formulation $\mathrm{Cs}\left[\mathrm{AlSiO}{ }_{6} \mathrm{H}_{2} \mathrm{C}\right.$. This mineral, those mentioned above and the zeolites, are all structuraliy similar, belonging to the tektosilicate group of silicate minerals. Pollucite is formed by reacting bentonite, pyrophyllite or kaolinite plus silica gel with a cesium salt in an alkaline solution at $80^{\circ}-100^{\circ} \mathrm{C}$. The aluminum and silicon are dissolved and the clay falls to an amorphous state. Spherical crystals of pollucite form out of the slurry over a period of about two days [9.4]. The formation of pollucite is dependent on the presence of cesium.

\subsubsection{Silica Rrocesses}

There are a variety of industrial processes which utilize silica reactions with waste to form solids. One such proprietary method is the Chemfix process (Chemfix, Inc., Kenner, La.). This process is based on the formation of crosslinked chain silicates similar to natural pyroxene minerals [9.5]. The Chemfix process mixes less than 10 volume 8 of silica and setting agent with the waste. This is accomplished by pumping liquid waste through the processing equipment, housed in a trailer, where the mixing takes place. Typically the waste is then pumped back to a holding lagoon where it solidifies over a period of several days. The Chenfix process is primarily intended for solidifying large volumes of heavy metal bearing industrial wastes and as cover and sealer for land fijls. Leach tests by Chenfix have shown significant retention of metals. Physically this material resembles a friable soil. 
It loses 16 wt water over a 100 hour period at ambient temperatures, shrinking considerably, but apparently this does not affect the leaching properties [9.5]. In several years of use, over 100 million gallons of waste have been treated with this material. What is apparently a similar product based on a silica-alkaline reaction was patented in Canada (Canadian Patent No. 1024277, issued January 10, 1978). Concentrations of heavy metals observed in the leachate were generally less than $1 \mathrm{ppm}$, reaching steady state values within several days [9.6]. Neither of these solidification techniques have been applied to radioactive waste disposal. It should be noted, however, that the physical form of these solids may not meet waste form criteria.

Workers at Savannah River Laboratory have experimented with the use of silica gels and silica flour as a possible in-tank solidification process [9.7]. This too is a silica-alkali reaction resulting in the formation of insoluble polysilicates. It was found that best results were obtained when precise proportions of silica to NaOH were mixed. An excess of either reactant does not produce a monolithic solid. Ratios of $3 \mathrm{~g}$ of silica gei or $4 \mathrm{~g}$ of silica flour reacted with $1 \mathrm{ml}$ of $8 \mathrm{M} \mathrm{NaOH}$ provided the best waste form. Aluminate ions present in SRP waste react readily with silicates to form insoluble aluminosilicates. This reaction required 1 week at $100^{\circ} \mathrm{C}$ and 1 month at $25^{\circ} \mathrm{C}$. It was found that solidification with this method increased the volune of the waste by a factor of 6 , a definite drawback. No leaching data are available for these experiments. It should be noted that silica gel has been used as an additive in cement waste forms to improve leachability.

\subsection{Mineralization Process Waste Encm Characteristics}

There is relatively little that is known about the characteristics of these materials as waste forms. Table 9.1 [9.1] reviews the properties of the minerals. There is little or no volume advantage achieved with these processes. Indeed there may in some cases be substantial volume increases. 
Table 9.1

Comparison of Alternative Clay Fixation Processes [9.1]

\begin{tabular}{|c|c|c|c|}
\hline Product Characteristics & Rich Clay Process & Lean Clay Process & Clay Calcination Process \\
\hline Mineral form & Cancrinite & Cancrinite & Nepheline \\
\hline Volume & $\begin{array}{l}1.3 \times \text { caustic terminal } \\
1 \text { iquor }\end{array}$ & $\begin{array}{l}2 \times \text { caustic terminal } \\
1 \text { iquor }\end{array}$ & $\begin{array}{l}0.8 \times \text { caustic terminal } \\
\text { liquor }\end{array}$ \\
\hline & $3 \times$ salt cake & $6 \times$ salt cake & $1.5 \times$ salt cake \\
\hline Leachability, $\mathrm{g} / \mathrm{cm}^{2}-$ day & $10^{-4}$ to $10^{-2}$ & $10^{-5}$ to $10^{-3}$ & $10^{-5}$ to $10^{-3}$ \\
\hline $\begin{array}{l}\text { Thermal and radiolytic } \\
\text { stability }\end{array}$ & Good & Good & Excellent \\
\hline Mechanical strength & Poor-to-good & Excellent & Excellent \\
\hline Bulk density, $\mathrm{g} / \mathrm{m} 1$ & 1.5 to 1.7 & 1.6 to 2.0 & 1.6 to 2.0 \\
\hline
\end{tabular}




\subsubsection{Chemical Compatibility of Wastes}

There are relatively few wastes with which these processes, particularly those forming the feldsparthoids, are compatible. Their fornation requires high alkalinity, together with the pr-sence of very precise types and amounts of waste, as described above. This makes these processes inappropriate for most types of waste. Silicate type processes appear to be somewhat more universally applicable, but there is little information available.

\subsubsection{Leachability}

Leachability information for the minerals produced by the clay fixation process is given in Table 9.1. Fraction release of cesium from cancrinite and sodalite are shown in Figure 9.2 as a function of kaclinite: salt ratio. Sodalite had a fraction release of 18 cs over a one week period. The leachabilities measured were $1.2 \times 10^{-3} \mathrm{~g} /\left(\mathrm{cm}^{2}\right)$ (day) for cancrinite, and $3.4 \mathrm{x}$ $10^{-4} \mathrm{~g} /\left(\mathrm{cm}^{2}\right.$ ) (day) for sodalite, as determined on powders at SRL [9.2]. These leach rates are similar to those reported from Hanford Engineering Development Laboratory. Increases of volume for both minerals were observed to be about 508 for NaOH: Raolinite: salt mole ratios of 4:2:1 [9.2]

\subsection{Advantages and Disadvantages}

Table 9.2 presents advantages and disadvantages associated with mineralization processes as represented by the clay reaction processes. Leachability and long term stability of these materials is good. However, aside from the many production limitations with these processes, there is generally a large volume increase with this type of waste form. 


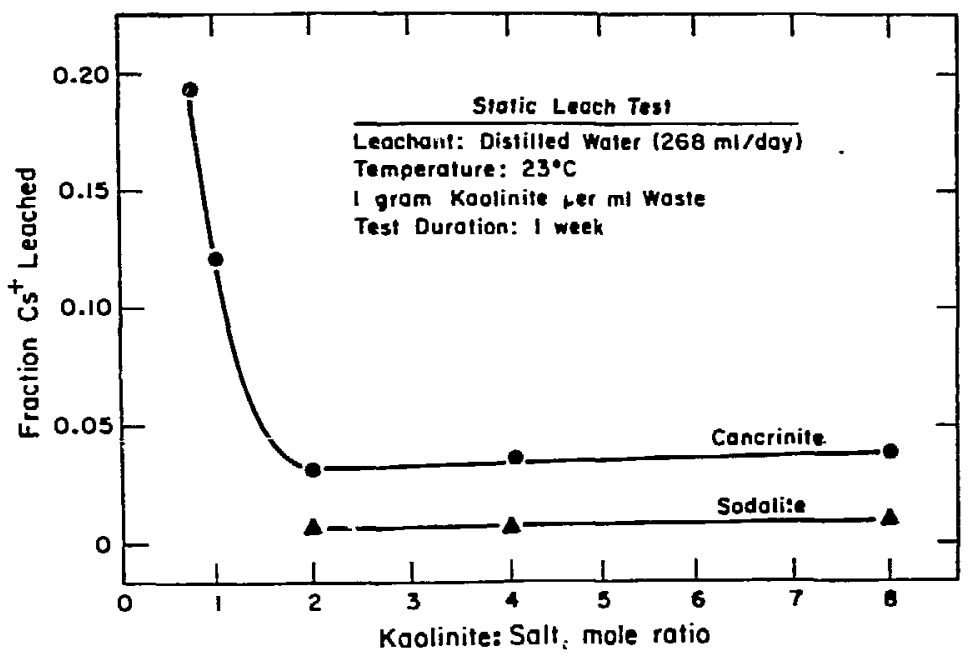

Figure 9.2. Fraction release from two minerals as a function of the kaolinite:salt ratio.

Table 9.2

Advantages and Disasvantages of Mineralization Processes (Clay Reaction Processes)

1. Low leachability

2. Long-term stability
1. Applicable only to very specific waste types and requires precise ratios of waste constituents and mineralization additives.

2. Results in as much as a 6 fold volume increase

3. Minerals formed would require incorporation into another matrix in order to make a monolithic waste form

4. Has not been demonstrated in actual usage 
[9.1] Delegard, C. H. and Barney, G. B., Eixation of Radioactive Waste by Reaction with Clays: Progress Report, ARH-ST-124, Richland, WA, Atlantic Richfield Hanford Company, 1975.

[9.2] Thampson, G. H., Evaluation of Mineralization Processes for SRP Wastes, DP-1389, Savanrah River Laboratory, 1975.

[9.3] Bauer, R.M., M., Cole, J. F. and Sticher, H., "Chemistry of Soil Minerals, Part V, Low Temperature Hydrothermal Transformations of Raolinite," Journal of the Chemical Society, (A), 24751968.

[9.4] Brownell, L. E., Kindle, C. H. and Theis, T. L., Review of Literature Rertinent to the Aqueous conversion of Radionuclides to Insoluble sil icates with Selected References and Bibliography (Revised), ARH-273I Rev., Rich land, WA, Atlantic Richfield Hanford Company, 1973.

[9.5] Salas, R. K., "The Disposal of Liquid Waste by Chenical Fixation/Solidification, The Chemfix Process, $"$ in Toxic and Hazardous Waste Disposal, Vol. I, R. J. Pojasek, Ann Arbor Science Publishers Inc., Ann Arbor, MI, 321, 1979.

[9.6] Krofchak, D., "Solidification-of Wastes," in Toxic and Hazardous Waste Disposal, Vol. 1, R. J. Pojasek, Ann Arbor Science Publishers, Inc., Ann Arbor, MI, 349, 1979.

[9.7] Thampson, G. H., Interim Solidification of SRP Waste with Silica, Bentonite or Phosphoric Acid, DP-1403, Savannah River Laboratory, Aiken, SC, 1976. 


\section{GLASS AS AN AGENT FOR LOW-LEVEN WASTE SOLIDIFICATION}

Glass processes are typically thought of for the solidification of highlevel waste. However, there are two processes which produce glassy waste forms while concurrently providing volume reduction for many types of lowlevel waste. Although these processes are beginning to be conmercialized, relatively little information is available for these processes. Other glass systems developed for the solidification of high-level waste are not considered.

\subsection{Solidification Processes Using Glass}

\subsubsection{Slag Fusion Process}

A system was developed at Eurochemic (Mol, Belgium) to produce a highly insoluble, basalt-like glass [10.1]. This procedure utilizes high temperature incineration at temperatures of $1500-1600^{\circ} \mathrm{C}$. The waste is reduced not to ash but to molten slag. The high temperatures eliminate many of the off-gas problems associated with plastics combustion. The waste itself may consist of both combustible and incombustible materials as long as there is at least 10-15\% mineral material to form the slag. The slag fusion system is composed of three parts: glove boxes for sorting, a high temperature incinerator, and an off-gas purification system. Combustion gases are blown through a layer of molten slag in order to remove particulates from the gaseous effluent (Fig. 10.1). The slag slowly drains from the bottom of the incinerator and can be formed either into granules or a solid monolith.

\subsubsection{Penberthy Pyro-Converter Process}

A system for incinerating and solidifying low-level waste in a glass matrix has been developed by Penberthy Electromelt International, Inc. 

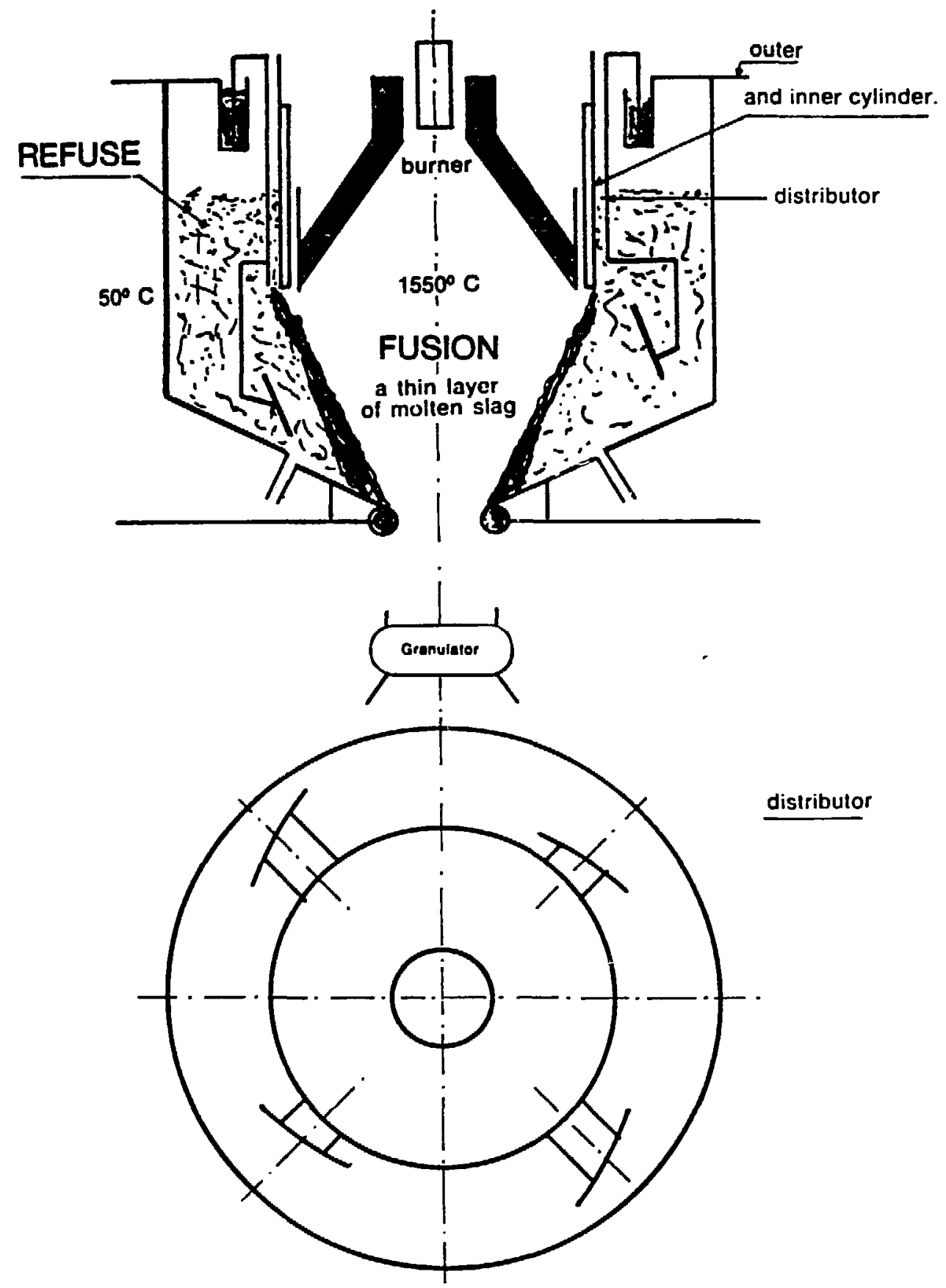

Figure 10.1. A schematic of a portion of the slay fusion process. 
(Seattle, washington) [10.2] . The process utilizes an electric immersion heated glass furnace (Fig. 10.2) similar to that used in the commercial glass industry. The waste is charged at one end of the furnace where it is incinerated in the air space above a pool of molten glass. Continuous addition of raw material for the glass provides an uncontaminated barrier, on the surface of the melt, to any volatilized radionuclides. The glass composition employed can be regulated to best accommodate the waste. For instance, the sodium oxide content of the waste controls the amount of waste which can be loaded in the glass. Alumina and calcia can be added to the raw materials for the glass to increase the chenical durability of the product. As combustible waste is added, it burns with the residue falling into the glass melt, giving very substantial volume reduction factors. Processing temperatures are approximately $1260^{\circ} \mathrm{C}$. The mixture of molten glass and incinerated ash is discharged from the low end of the furnace into cooled drums. Spent fiberglass filter pads for dust collection can be pushed into the melt by the fresh replacement pad.

\subsection{Glass Waste Form Characteristics}

There is little information directly available on the relevant characteristics of the waste forms produced by these processes. A considerable body of information for glasses similar to the Penberthy process product may be found in commercial glass property literature. A large amount of data has been developed for high-level waste glasses. However, most of this information ceals with different glass compositions, waste types and high activity loadings which are not relevant to low-level waste processing. 


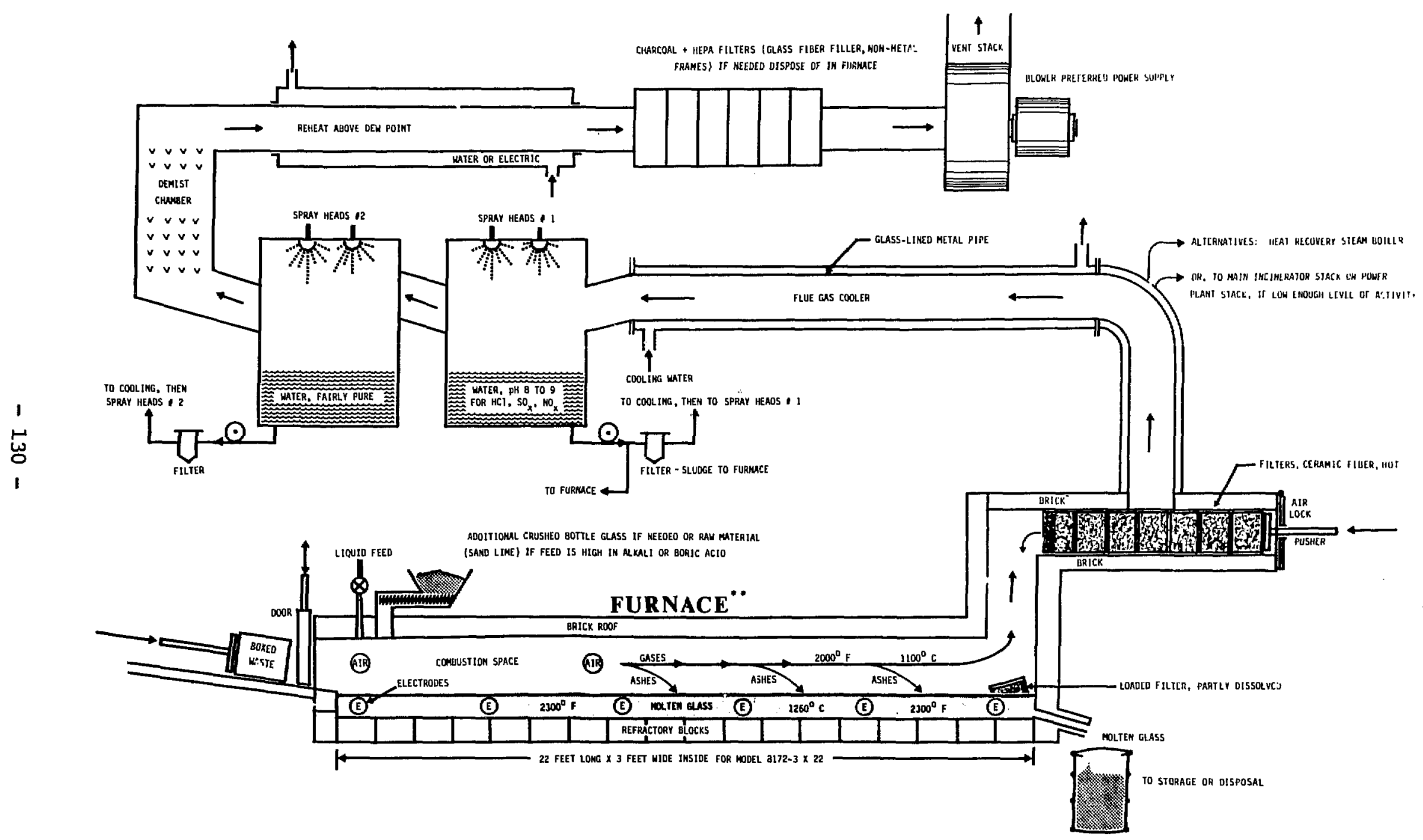

Figure 10.2. The Penberthy pyro-converter glass system. 


\subsubsection{Chemical Compatibility of Waste}

The two systems discussed here, which produce glassy waste forms, also provide volume reduction by incinerating combustible wastes. As a result, most materials which may be directly incompatible with glass are converted to oxides. Some compatibility considerations are anticipated if a single phase glass is desired. In addition, the amount of waste oxides that can be incorporated is linited. The major requirement of the slag fusion process is that there must be sufficient mineral content in the waste to produce slag.

\subsubsection{Leachability}

Relatively little information has been published on the leaching characteristics of the products discussed here. The slag fusion material has been shown to exhibit low leachability in limited testing. Leach tests ( 24 hour duration, running water) with non-radioactive materials have resulted in leach rates of $10^{-10} \mathrm{~g} /\left(\mathrm{cm}^{2}\right)$ (day) for copper, $10^{-8} \mathrm{~g} /\left(\mathrm{cm}^{2}\right)$ (day) for iron, and $10^{-5} \mathrm{~g} /\left(\mathrm{cm}^{2}\right)$ (day) for sodium. The glassy granules are composed primarily of silicon and iron oxides and range in diameter from $0.5 \mathrm{~mm}$ to $5 \mathrm{~mm}$. The offgases are relatively dust-free even before filtering [10.1] •

Pertimer et al. [10.3] at the University of Maryland have tested products of the pyro-converter process. Leach tests in distilled water indicated no leaching above detectable limits in up to 35 days; two samples showed some leaching at 35 days and all samples indicated leaching after 56 days. Concentrations within samples, concentrations within leachates and detection limits were not given. More complete information is expected to be available in the near future. 


\subsubsection{Mechanical Strength}

Samples of the pyro-converter product were analyzed for compressive strength and homogeneity for solidification of a non-radicactive ash [10.3]. As much as $34 \mathrm{~kg}$ of ash were charged into $68 \mathrm{~kg}$ of molten borosilicate glass in $6.8 \mathrm{~kg}$ loads. Various ash contents in the glass were obtained. While a few of the sarmles were homogeneous, most samples, particularly those at high concentrations (1 part ash to 2 parts glass), showed stratification of the ash within the glass. The samples also contained voids in the cooled product. Compressive strengths of two samples of the glass-waste product were 29,300 psi and 32,700 psi. In comparison, the glass without waste had a compressive strength of 118,900 psi. Even samples with the ash, however, have an exceptionally high compressive strength. Breakage occurs along the strata of ash.

\subsubsection{Radiation and Thermal Stability}

While a large body of information exists for the thermal and radiation stability properties of various glasses, little is available for glasses of the compositions discussed here.

\subsection{Advantages and Disadvantages}

Table 10.1 presents the advantages and disadvantages of glass processes for the solidification of low-level wastes. Relatively little work has been performed in this area although a large body of information exists for glass as a high-level waste form. A major advantage of these processes is the concurrent volume reduction of waste as it is incorporated into the matrix. A major disadvantage is the elevated temperature required for the process. 


$$
\text { Table } 10.1
$$

Advantages and Disadvantages of Glass Solidification

1. Provides volume reduction as well 1. High temperature process as solidification

2. Waste form probably has very low leachability

3. Raw materials are inexpensive and readily available
2. Relatively expensive processing equipment and associated systems

3. Applicability to specific wastes is not well defined

4. Inhomogeneous product 
[10.1] Van DeVoorde, N., Dumont, G., Claes, J., Taeymans, A., VanGeel, J. and Dejanghe, P., "An Integrated System for the Conditioning of Liquid Waste Concentrates," in Management of Radioactive Wastes from the Nuclear Fuel cycle, International Energy Agency, Vienna, Austria, pp. 141-152, 1976.

[10.2] Penberthy Pyro-Converter, Model 8172 for Radioactive, Toxic and Other Hazardous Wastes, Penber'hy Electromelt International, Inc., Seattle, Washington.

[10.3] Pertimer, G. A., Munno, F. J. and Robertson, P. W., "Analysis of Simulated Low-Level Waste Glass Forms, " Transactions of the American Nuclear Society, 35, p. $89,1980$. 


\section{POLYMER MODIFIED GYPSUM CEMEENT (ENVIROSTONE)}

Gypsum type materials have been used to solidify low-level aqueous wastes. For instance, plaster of paris $\left(\mathrm{CaSO}_{4} \cdot 1 / 2 \mathrm{H}_{2} \mathrm{O}\right)$ has been employed at the university of Illinois at Urbana-Champaign to solidify small batches (approximately gallon size) of liquid wastes [11.1]. The Mound Facility at Miamisburg, Ohio has used plaster of paris and vermiculite for the solidification of aqueous tritiated wastes.

When gypsum $\left(\mathrm{CaSO}_{4} \cdot 2 \mathrm{H}_{2} \mathrm{O}\right)$ is heated to between $128^{\circ} \mathrm{C}$ and $163^{\circ} \mathrm{C}$, one and a half molecules of water are driven off to form the hemihydrate, plaster of paris $\left(\mathrm{CaSO}_{4} \cdot 1 / 2 \mathrm{H}_{2} \mathrm{O}\right)$. If heated to $163^{\circ} \mathrm{C}$ or higher, all hydration water is lost, forming the anhydrite. When the hemihydrate powder is mixed with water, it becomes hydrated, forming the less soluble dihydrate, gypsum. The gypsum falls out of solution and forms radiating networks of interlocking crystals.

\subsection{Description of Envirostone}

United States Gypsum Company has recently developed a proprietary solidification agent which is a polymer modified cement called Envirostone. This material was developed in particular for problem wastes such as boric acid wastes, oils and other organic liquids. Envirostone powder, the waste and, depending on the waste type, water are blended into a relatively fluid "cream." When organic liquids are being solidified, a proprietary additive is also employed to condition the organic material. Envirostone can be prepared using standard cement mixing equipment. In-line mixing may be less troublesome than with cement because of the greater fluidity of the mixed prociact. Setting generally takes place in about an hour and is an exothemic reaction. Envirostone solidifies best at a mixture pH of 6 or less. 


\subsection{Waste Form Characterization}

Some characterization of Envirostone waste forms has been undertaken by U.S. Gypsum Company [10.11. A full-scale (55 gallon drum) test of Envirostone for the solidification of boric acid waste was prepared, mixing (for 13 minutes) 345 lbs. of 12 wto boric acid solution with $380 \mathrm{lbs}$. of the Envirostone agent. Maximum internal temperature elevation for this full-scale waste form was $30^{\circ} \mathrm{C}$. Gypsum procucts typically increase in volume slightly $(0.5 \%)$ on setting but no drum distortion was observed. Setting required 20 minutes.

\subsubsection{Leachability}

Leaching of Envirostone samples employing the ANS 16.1 test demonstrated that Envirostone leachability is relatively insensitive to the waste streams. Typical values for laboratory size specimens (279g and surface areas of $40.6 \mathrm{~cm}^{2}$ ) leached for 5.9 days are: $9 \times 10^{-2} \mathrm{~g} /\left(\mathrm{cm}^{2}\right)$ (day) for ${ }^{60} \mathrm{Co}, 6 \mathrm{x}$ $10^{-3} \mathrm{~g} /\left(\mathrm{cm}^{2}\right)$ (day) for ${ }^{85} \mathrm{Sr}, 1 \times 10^{-1} \mathrm{~g} /\left(\mathrm{cm}^{2}\right)$ (day) for ${ }^{137} \mathrm{Cs}$ and $8 \times 10^{-3}$ $\mathrm{g} / \mathrm{cm}^{2}$ ) (day) for ${ }^{144} \mathrm{Ce}$ (calculated from [1l.1]).

\subsubsection{Compressive Strength}

Compressive strengths of Envirostone samples. were measured to range from 1450 psi for a laboratory size waste form containing 58.8 wtz of a 12 wto boric acid concentrate waste to $600 \mathrm{psi}$ for a waste form containing 66.7 wtz boric acid waste [11.1]. Waste forms containing dewatered ion exchange resin had compressive strengths ranging from 700 psi to 120 psi for samples containing 50 wto and 80 wto waste respectively. Samples made with oil as waste had compressive strengths that ranged from 615 psi for 288 waste to 100 psi for 578 waste. 


\subsection{Advantages and Disadvantages}

While there is relatively little known about Envirostone as a waste form, certain advantages are evident fram the laboratory work that has been done. This material can accept significant quantities of organic liquids or acidic waste and still form a monolithic solid.

\section{References for Section 11}

[11.1] Joss, M.D., Lange, R.G. and Rosenstiel, T.L., Envirostone Gyosum Cement: Eormulated Gypsum Product for Solidification of Low-Level Radioactive Waste From Nuclear Power Stations, United States Gypsum Company, Chicago. 
12. POLYMER IMPREGNATED CONCREIE AS AN AGENI FOR LOW-LEVEI WASTE SOLIDIFICATION

In the early 1970 's, a "hybrid" waste form was developed at Brookhaven National Iaboratory which utilized polymers to improve the properties of concrete waste forms. This concept first incorforates the waste in a cement matrix and then impregnates this waste form with a polymerizable material to seal off cement porosity. Resultant properties begin to approach those of multibarrier waste forms employed for high-level wastes.

\section{I Description of Polymer Impreanated concrete}

Polymer impregnated concrete (PIC) is a precast concrete composite, containing liquid or solid radioactive waste, which has been impregnated with a monomer which is subsequently polymerized [12.1]. In this way void spaces within the cement are filled, reducing leachability and improving mechanical properties. This waste form has been used for the solidification of various waste types, including tritiated water, $\mathrm{Al}_{2} \mathrm{O}_{3}$ calcine composites, sodium nitrate and zeolites. Polymer impregnated concrete processes have also been applied to waste solidification in Europe [12.2] .

\subsection{Solidification Process Using Polymer Impregnated concrete}

Processes using polymer impregnated concrete waste forms start with typical cement waste forms. The cement is then aried at $120^{\circ} \mathrm{C}$ to drive off any unreacted moisture. Weight losses of about 2.5 wto are observed [12.3]. The dried cement waste form is placed in a chamber which is evacuated and then filled with monomer. Drying improves impregnation by removing water from cement porosity. Waste forms can be impregnated without drying, however, to be successful, the waste form formulations must be properly selected. The monaner employed is typically camposed of $70 \%$ styrene and $30 \%$ divinylbenzene (DVB). 
Other monomers can be used, however, the monomer should have a low viscosity. Benzoyl peroxide $(0.5 \mathrm{wt} z)$ is added to the monomer as a polymerization catalyst. The styrene-DVB mixture was chosen because of its low viscosity, and also its thermal and radiation stability. The waste form is allowed to soak in the monomer for about four hours and is then placed in a curing oven for another four hours at $50-70^{\circ} \mathrm{C}$. One-inch diameter by three-inch long cylindrical specimens absorbed 56 wto of the monomer. Waste forms incorporating $\mathrm{Al}_{2} \mathrm{O}_{3}$ calcine took up about 14 wtz of the monomer because of the high porosity of the calcine [12.4]. Additional curing may be achieved by exposing the waste form to radiation. Crosslinking of the polymer chains becomes more complete in this manner, improving the strength of the product by about $10 \%[12.1,12.3]$. A schematic of the process is given in Figure 12.1.

\subsection{Chemical compatibility of the Wastes}

Polymer impregnated concrete waste forms can be produced, incorporating any wastes that can be solidified in concrete.

\subsection{Waste Form Characteristics}

\subsubsection{Leachability}

The bulk leach rates for cesium and strontium are shown in Table 12.1 [12.5] for two types of waste in cement and in polymer impregnated concrete waste forms. The PIC bulk leach rate was at least 2 orders of magnitude less than the respective cement waste form. Indeed, the activity levels of the PIC leachants were often below detection limits, accounting for the "less than" values in Table 12.1 [12.5]. Additional leach resistance can be obtained by providing a thin polymer film on the waste form surface by a subsequent treatment step. 


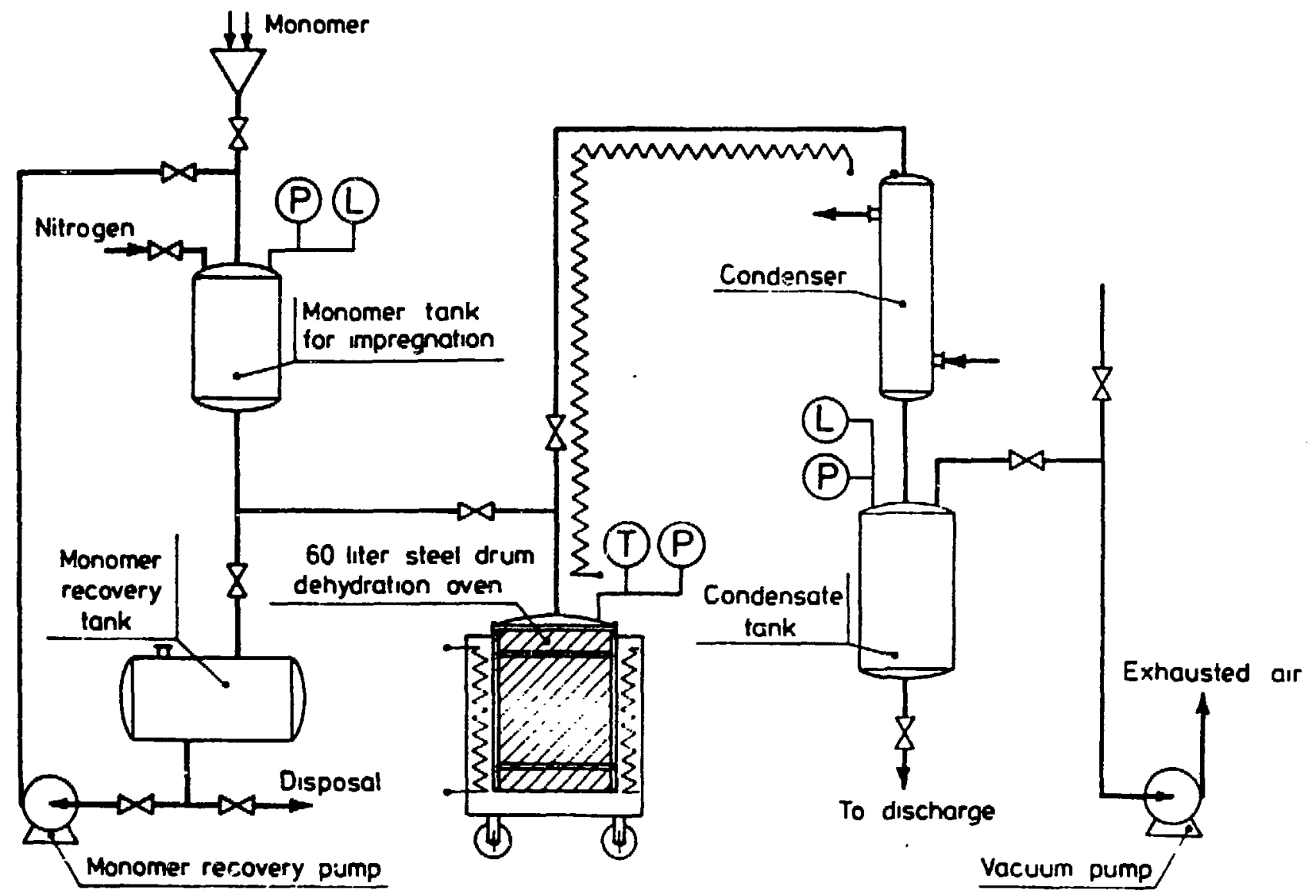

Figure 12.1. Polymer impregnated concrete system. 
TABLE 12.1

Cesium and Strontium Leach Rates for Selected Concrete and PIC Formulations

\begin{tabular}{|c|c|c|c|c|c|c|c|}
\hline \multicolumn{5}{|c|}{ Formulation, wt\% } & \multirow{2}{*}{$\begin{array}{l}\text { Polymer } \\
\text { Loading } \\
\text { wt\% }\end{array}$} & \multicolumn{2}{|c|}{$\begin{array}{ll}\text { Bulk Leach Rate after } \\
143 \text { days } & \mathrm{g} /\left(\mathrm{cm}^{2} \text { day }\right)\end{array}$} \\
\hline Cement & Zeolite & Sludge & Sand & Water & & Cesium & Strontium \\
\hline 35.0 & $12.5^{\mathrm{a}}$ & --- & 35.0 & 17.5 & -- & $6.82 \times 10^{-6}$ & $2.50 \times 10^{-5}$ \\
\hline 35.0 & $12.5^{\mathrm{a}}$ & -- & 35.0 & 17.5 & 8.69 & $0.95 \times 10^{-8}$ & $9.61 \times 10^{-8}$ \\
\hline 36.3 & $4.2^{b}$ & $8.3^{c}$ & 35.0 & 16.2 & --- & $4.63 \times 10^{-5}$ & $9.27 \times 10^{-7}$ \\
\hline 36.3 & $4.2^{b}$ & $8.3^{c}$ & 35.0 & 16.2 & 8.18 & $<1.04 \times 10^{-7}$ & $<9.72 \times 10^{-8}$ \\
\hline
\end{tabular}

${ }^{\mathrm{a}}$ Contains 0.11 meq cesium/g and 0.34 meq strontium/g.

${ }^{b}$ Contains 0.32 meq cesium/g.

${ }^{c}$ Contains $0.50 \mathrm{meq}$ strontium/g. 


\subsubsection{Radiation Stability}

Samples of polymer impregnated concrete were ganma irradiated to a total dose of $10^{10}$ rads using ${ }^{60} \mathrm{Co}$. The compressive strength of PIC was not significantly affected. The irradiated sample had values of 12,000 psi, while the compressive strength of the control was 12,100 psi. Leachability of the cortrol was $4.5 \times 10^{-4} \mathrm{~g} /\left(\mathrm{cm}^{2}\right)$ (day) while the irradiated sample was $2.6 \times 10^{-4}$ $\mathrm{g} /\left(\mathrm{cm}^{2}\right)$ (day). Radiolytic gas production for a dose of $10^{10}$ rads was $\mathrm{G}\left(\mathrm{H}_{2}\right)=$ 0.016 molecules $/ 100 \mathrm{eV}$ absorbed, and $\mathrm{G}\left(\mathrm{CO}_{2}\right)=0.0031$ molecules $/ 100 \mathrm{eV}$ absorbed. The radiolytic hydrogen genrration ratio observed was lower than that expected for the amount of polystyrene in the waste form. It is believed that much of the hydrogen is absorbed on the cement surfaces [12.6]

\subsection{Advantages and Disadvantages}

The principal advantage of a polymer impregnated concrete waste form is the significantly decreased leachability. Very large improvements in mechanical properties also result. Such high strengths probably provide little benefit in disposal, however, the improvements over untreated cement waste forms in many cases is significant. The major disadvantage is the increased complexity of the process. 
[12.1] Manowitz, B. et al., Development of Durable Long-Term Radiactive Waste Composite Materials, Progress Report No. 3, Brookhaven National Laboratory, Upton, NY, 1973.

[12.2] Donato, A., "Incorporation of Radioactive Wastes in Polymer Impregnated Cement, " in: Management of Radioactive Wastes From the Nuclear Fuel Cycle, Volume II, International Atomic Energy Agency, Vienna, Austria, 1976.

[12.3] Development of Durable Iong-Term Radiactive Waste Composite Materials, Progress Report No. 1, Brookhaven National Laboratory, Upton, NY, 1972.

[12.4] Development of Durable Iong-Term Radioactive Waste Composite Materials, Progress Report No. 4, Brookhaven National Laboratory, Upton, NY, 1973.

[12.5] Colombo, P. and Neilson, R. M., Jr., "Some Techniques for Solidification of Radioactive Wastes in Concrete," Nuclear Technology, 32 (1), 30, 1977.

[12.6] Manowitz, B. et al., Development of Durable Long-Term Radioactive Waste Composite Materials, Progress Report No. 6, Brookhaven National Laboratory, Upton, NY, 1974. 